National Mapping Program

Technical Instructions

Data Users Guide 3

\title{
USTapara
}

\section{Digital Line Graphs from 1:2,000,000-Scale Maps}

Data Users Guide 


\section{DATA USERS GUIDES}

1: $\quad$ Digital Line Graphs from 1:24,000-Scale Maps

2: $\quad$ Digital Line Graphs from 1:100,000-Scale Maps

3: $\quad$ Digital Line Graphs from 1:2,000,000-Scale Maps

4: $\quad$ Land Use and Land Cover Digital Data from 1:250,000- and 1:100,000-Scale Maps

5: $\quad$ Digital Elevation Models

6: $\quad$ Geographic Names Information System

7: $\quad$ Alaska Interim Land Cover Mapping Program

Data Users Guides 1-7 generally replace the Geological Survey Circular 895.

Questions regarding availability and ordering of US GeoData (all types of digital cartographic and geographic data produced and distributed by the U.S. Geological Survey) should be addressed to:

Earth Science Information Center

U.S. Geological Survey

507 National Center

Reston, Virginia 22092

(703) $860-6045$

Technical questions and comments should be addressed to:

Branch of Technical Management

U.S. Geological Survey

510 National Center

Reston, Virginia 22092 


\section{UNITED STATES \\ DEPARTMENT OF THE INTERIOR}

U.S. GEOLOGICAL SURVEY

DIGITAL LINE GRAPHS FROM 1:2,000,000-SCALE MAPS

Data Users Guide 3

Reston, Virginia

1990 
First printing, 1986

Second printing (revised), 1990 


\section{CONTENTS}

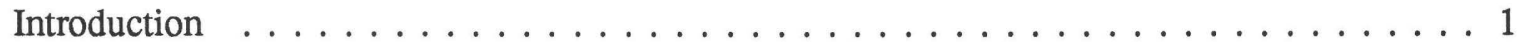

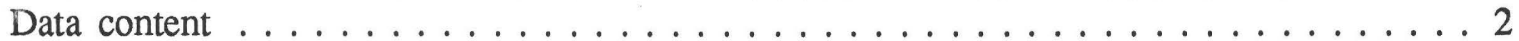

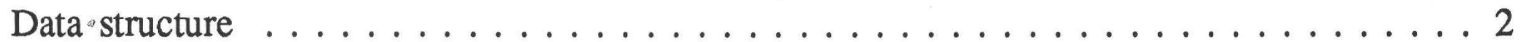

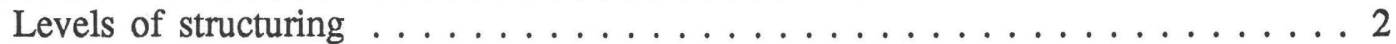

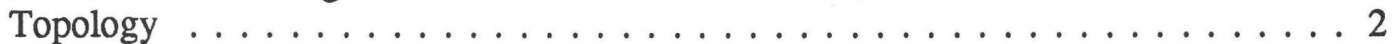

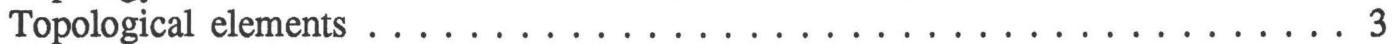

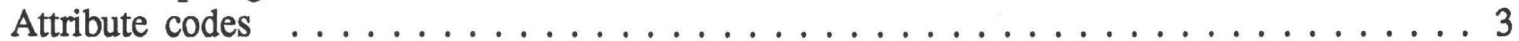

Major attribute codes ........................ 5

Minor attribute codes . . . . . . . . . . . . . . . . . 5

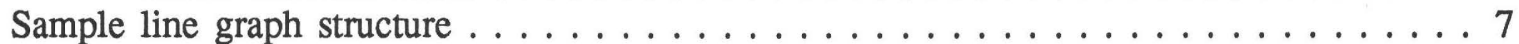

Graph theory in DLG data . . . . . . . . . . . . . . . . . . 12

Distribution formats $\ldots \ldots \ldots \ldots \ldots \ldots \ldots \ldots \ldots \ldots$

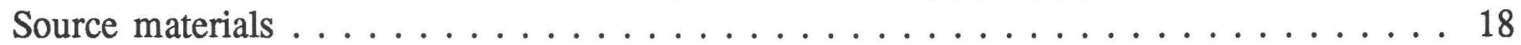

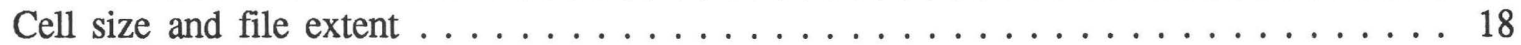

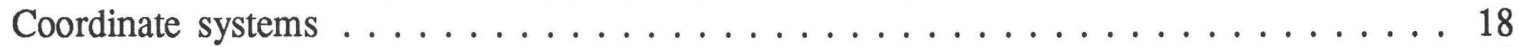

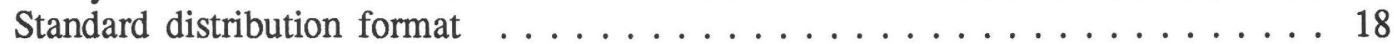

Optional distribution format .................... 20

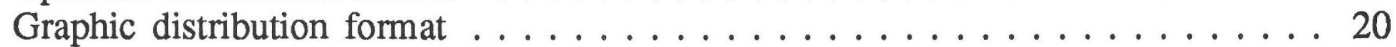

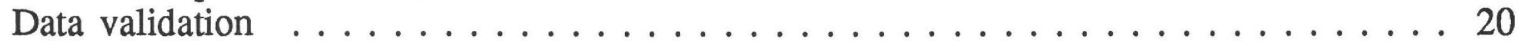

Appendix A. Standard DLG distribution format (record contents) . . . . . . . . . 25

B. Optional DLG distribution format (record contents) . . . . . . . . . 36

C. Graphic format . . . . . . . . . . . . . . . . . . . . . 47

D. Map projection parameters . . . . . . . . . . . . . . . . 48

E. DLG attribute codes . . . . . . . . . . . . . . . . . . . . . 49

F. Coordinate conversion ...................... 58

G. Sample DLG data file (standard distribution format) . . . . . . . . . . . . 59

H. Sample DLG data file (optional distribution format) . . . . . . . . . 65

I. Data sources and currency ................... 70

\section{ILLUSTRATIONS}

Figure 1. Map elements showing roads, railroads, buildings, streams, lake and forest areas .................. 4

2a. Pecos River, Southeastern New Mexico

Scale $1: 2,000,000 \ldots \ldots \ldots \ldots$. . . . . . . . . . . . . . 8

2b. Rivers and water bodies, New Mexico

Scale $1: 5,000,000 \ldots \ldots \ldots \ldots \ldots$

2c. Rivers and water bodies, New Mexico

Scale $1: 10,000,000 \ldots \ldots \ldots \ldots \ldots \ldots$ 


\section{ILLUSTRATIONS--continued}

Figure 3. Sample line graph $\ldots \ldots \ldots \ldots \ldots \ldots \ldots \ldots \ldots \ldots$

4. Window from the Arizona-New Mexico, 1:2,000,000-scale sectional map of the National Atlas of the United

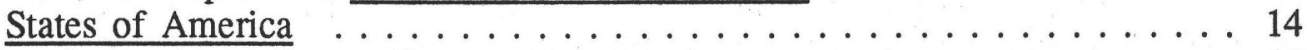

5. Sample topology, Catron County, New Mexico ............. 15

6. Multistate cells used for Digital Line Graphs

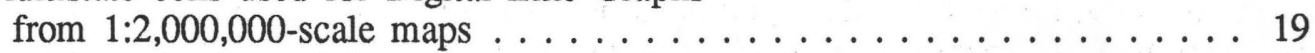

7. Location of origin of file reference coordinates $\ldots \ldots \ldots \ldots \ldots \ldots 20$

\section{TABLES}

Table 1. Major codes used for DLG base categories $\ldots \ldots \ldots \ldots \ldots \ldots$

2. Description of the topological elements and relationships of a sample line graph $\ldots \ldots \ldots \ldots \ldots \ldots \ldots 11$

3. Selected sample of standard format DLG-3 records of Catron County, New Mexico $[\mathrm{N}$, node; A, area; L, line $] \ldots \ldots \ldots 16$

4. Standard, optional, and graphic DLG format . . . . . . . . . . 17 


\section{INTRODUCTION}

The Earth Science Information Centers (ESIC) distribute digital cartographic/geographic data files produced by the U.S. Geological Survey (USGS) as part of the National Mapping Program. Digital cartographic data files may be grouped into four basic types. The first of these, called a Digital Line Graph (DLG), is line map information in digital form. These data files include information on planimetric base categories, such as transportation, hydrography, and boundaries. The second type, called a Digital Elevation Model (DEM), consists of a sampled array of elevations for a number of ground positions that are usually at regularly spaced intervals. The third type is Land Use and Land Cover digital data, which provides information on nine major classes of land use such as urban, agricultural, or forest as well as associated map data such as political units and Federal land ownership. The fourth type, the Geographic Names Information System, provides primary information for all known places, features, and areas in the United States identified by a proper name.

The digital cartographic data files from selected sources currently available from ESIC include the following:

- Digital Line Graphs (DLG)

$--1: 24,000$-scale

$--1: 62,500$-scale

$-1: 63,360$-scale

$-1: 100,000$-scale

$--1: 2,000,000$-scale

- Digital Elevation Models (DEM)

--7.5 -minute

--15 -minute

--30-minute

--1-degree

- Land Use and Land Cover digital data

--1:250,000- and 1:100,000-scale Land Use and Land Cover and associated maps

--1:250,000-scale Alaska Interim Land Cover

- Geographic Names

The digital data are useful for the production of cartographic products such as plotting base maps and for various kinds of spatial analysis. A major use of these digital cartographic/geographic data is to combine them with other geographically referenced data enabling scientists to conduct automated analyses in support of various decisionmaking processes.

Any use of trade, product, or firm names in this publication is for descriptive purposes only and does not imply endorsement by the U.S. Government. Manuscript approved for publication September 4, 1986. 
This document describes DLG's prepared from the 1:2,000,000-scale sectional maps (U.S. regions) of the National Atlas of the United States of America.

\section{DATA CONTENT}

The DLG data files derived from the 1:2,000,000-scale maps contain selected base categories of cartographic data in digital form. The data files are derived from the sectional maps of the 1970 National Atlas of the United States of America. The following categories are included in current 1:2,000,000-scale DLG files:

- $\quad$ Boundaries -- This category of data includes boundary information collected in two separate subcategories: (1) Political Boundaries and (2) Administrative Boundaries.

- $\quad$ Hydrography -- This category of data includes features collected in three separate subcategories: (1) Streams, (2) Water Bodies, and (3) Hypsography (Continental Divide only).

- Transportation -- This category of data includes major transportation systems collected in three separate subcategories: (1) Roads and Trails, (2) Railroads, and (3) Cultural Features (airports and Alaska pipeline).

\section{DATA STRUCTURE}

\section{Levels of Structuring}

The term DLG is employed by the USGS to describe a digital map data set in vector form. Originally, three levels of DLG data (DLG-1, DLG-2, and DLG-3) were proposed; these levels were differentiated by their positional accuracy, level of attribute coding, and relational spatial information. It was found, however, that the widest user-community would be served by producing DLG-3 data, which have the full range of attribute codes and are fully topologically structured. These two properties are required by users whose work includes both graphic and analytic applications. Therefore, all DLG data in the National Digital Cartographic Data Base are level 3.

\section{Topology}

Data collection from 1:2,000,000-scale maps was exclusively directed toward producing fully topologically structured level-3 DLG data referred to as DLG-3. The DLG-3 concept is based on graph theory in which a two-dimensional diagram is expressed as a set of nodes (points in space) and links (line segments connecting nodes) in a manner that explicitly expresses logical

relationships. Applied to a map, this concept is used to encode the digital data with the spatial relationships among map elements that are obvious when the map is examined visually. The spatial relationships include such concepts as adjacency and connectivity between features on the map. The abstraction of the map data according to the rules of graph theory preserves the spatial relationships inherent in the map graphic and creates a logical and consistent data file structure for computer processing. A digital file of cartographic or geographic data that maintains the spatial relationships inherent in the map is called a topologically structured data file. A topologically 
structured data file can support simple graphic applications, such as plotting streams and roads for base maps, as well as more advanced applications, such as computations involving areas and lines and their spatial relationships.

\section{$\underline{\text { Topological Elements }}$}

A DLG-3 file is composed of three separate, but related, types of elements: nodes, lines, and areas. Nodes define the location of the end-points of every line, and a single node may mark the start or end of one or more lines. Intersections of linear features and significant points on linear features are marked by nodes because at that point the linear feature is subdivided into line segments.

A line is an ordered set of points that describes the position and shape of a linear feature on the map. Each line starts at a node and ends at a node and, thus, has both an explicit direction and a left-right connotation. The direction of the line is arbitrarily chosen at the time of digitizing. Lines connect to each other at nodes, and, by this definition, a line does not cross itself or any other line. A line may describe the boundary between two map features, such as counties, or may define a map feature by itself, such as a road. A special line, called a degenerate line, is used to define features symbolized as independent points on a map. A degenerate line starts and ends at the same node, has two identical coordinate pairs, has zero length, and is totally enclosed inside one map area.

An area is a portion of the map bounded by lines. All portions of the map must be assigned to some area. Each area is identified in a DLG-3 data file by an arbitrary point chosen to represent the characteristics of the area; the point is not required to be inside the area it represents. Every DLG data file will have at least two areas identified: one representing the area covered by the file and the other representing the area outside the coverage of the file. Additional areas will be defined as necessary to subdivide the area covered by the file. Polygons as unique features are not defined explicitly in a standard DLG file. However, polygons can be constructed using line-area linkages built into the DLG data structure.

\section{ATTRIBUTE CODES}

In addition to locational and topological information, DLG data elements may have explicitly encoded attributes. Attribute codes, also called feature codes or classification attributes, are used to describe the map information represented by a node, area, or line. For example, the attribute code for an area might identify a lake or glacier; the attribute code for a line might identify a road, railroad, stream, or shoreline (fig. 1). The codes are based on the cartographic features symbolized on the sectional maps of the 1970 National Atlas of the United States of America.

The map symbology of the source material used during digitizing and encoding of data elements has a strong influence on the overall classification strategy. A listing of all the attribute codes currently assigned and used in the 1:2,000,000-scale DLG files is given in Appendix E. 


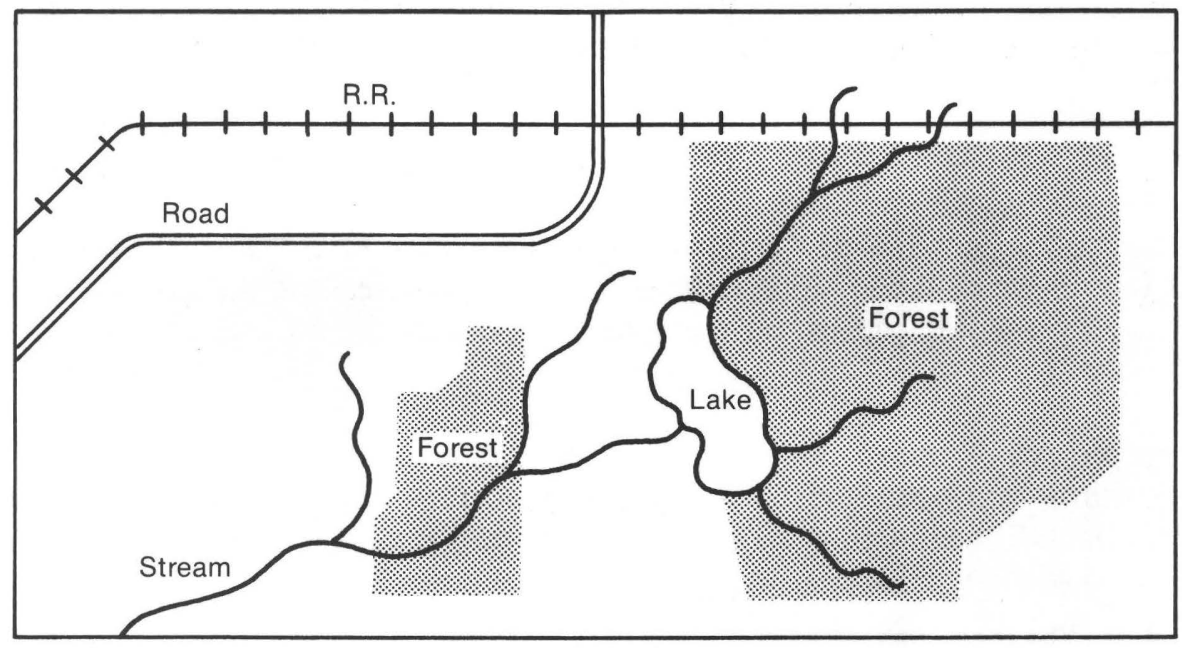

Figure 1.--Map elements showing roads, railroads, buildings, streams, lake, and forest areas.

Each attribute code identifies the major category to which a data element belongs, as well as the specific nature of the element. Codes also may provide additional descriptive information. Most elements are uniquely described by a single attribute code. Others, however, may require two or more codes for a complete description. If multiple attributes are needed to describe an element, the order is not significant. Allowing for a variable number of attribute codes creates an open-ended structure to which information may be added at any time. It is not necessary for each element to have associated attributes; in general, attribute codes are not assigned to an element if the attributes can be derived based on relationships to adjacent elements.

In conventional DLG data files, features are described as they are symbolized or labeled on the source map. For the 1:2,000,000-scale data, however, additional information about the map features is included through a special attribute coding scheme. These codes not only describe the digitized features in a generic sense, but provide a means of selecting map features based on some indices of the significance of the features. These special attribute codes are provided to assist the user in selecting the features to be displayed on maps of various scales and themes. Because of the varying nature of the themes of data digitized, the indices of feature "significance" differs between data overlays.

A DLG attribute code is composed of two distinct numeric fields: a three-digit major code, and a four-digit minor code. In the digital file, the major and minor attributes are encoded in two integer fields of six digits, flush right with leading blanks (FORTRAN 2 I6 format). In this document, major codes are presented as three digits, and minor codes are presented as four digits. Leading zeros are shown for clarity; for example: 0900104. 


\section{Major Attribute Codes}

A list of the major codes and the categories they represent is contained in table 1 . The first two digits of the major code (including leading zeroes) uniquely identify the category to which the described element belongs. The third digit of the major code is used to modify the minor code in two ways:

- If zero, the minor code represents a description or classification of the element.

- If non-zero, the minor code which follows is a parameter requiring special interpretation according to instructions given in the codes for each category (see next section).

Table 1.--Major codes used for DLG base categories

\begin{tabular}{ll}
\hline Major Code & \multicolumn{1}{c}{ Base Category } \\
\hline 040 & Water Bodies \\
090 & Political and Administrative Boundaries \\
100 & Transportation systems -- Roads and Trails \\
290 & Special line attribute codes for $1: 2,000,000$-scale data \\
\hline
\end{tabular}

NOTE: The coding scheme utilizing the major codes 040, 090, 100, and 290 applies only to $1: 2,000,000$-scale DLG data sets. The codes in the series 040,090 , and 100 are available only in the standard and optional DLG formats (described below). In the graphic data format, only the last two digits of the 290 -code series are carried in the data.

\section{Minor Attribute Codes}

In the 1:2,000,000-scale data sets, two separate schemes are used to encode minor attribute codes: scheme one is used with the major code series 040,090, and 100, and scheme two is used with major code series 290 . These two schemes will be addressed separately.

\section{Scheme One: Minor Codes in the 040, 090, and 100 Series}

The codes in the 040 and 090 code series are used for area elements in the water body and boundary (both political and administrative) categories, respectively. The codes in the 100 code series are applied to the roads and trails category. If the third digit of the major code is zero, the minor code is interpreted to describe the file element in a generic sense (for example, as a lake, forest, or park). If the third digit of the major code is non-zero, the minor code is interpreted as identifying the file element representing part of a particular feature (for example, as the State of Virginia, Fairfax County, or Interstate 95). These codes are not included in the graphic data distribution format. 
Examples of these attribute codes include:

0400100

The major code 040 indicates the water body category. The minor code 0100 identifies the feature as a perennial lake or pond.

0900104

0910051 ,

0920059

The major code 090 indicates one of the boundary categories. The minor code 0104 identifies the feature as a national forest or grassland.

The major code 091 indicates a State in the boundary category. Because the last digit of the major code is non-zero, the minor code is a parameter. The minor code 0051 is the Federal Information Processing Standards (FIPS) code for the State of Virginia. Similarly, the major code 092 indicates a county in the boundary category. The minor code 0059 is the FIPS code for Fairfax County.

1020095

The major code 102 indicates an interstate highway in the roads and trails category. Because the last digit of the major code is non-zero, the minor code is interpreted as a parameter code. The minor code 0095 indicates that the element with which this code is associated is part of Interstate 95.

Scheme Two: Minor Codes in the 290 Series

During the planning of the 1:2,000,000-scale data sets, it was decided that the data should support the generation of a variety of maps of different scales and themes. During the process of making different maps, it is necessary to change the amount of data displayed to support the theme or scale of the map. One of these changes is to control the selection of features to be displayed based on some indices of significance or importance.

The 290-code series represents an attempt to encode selected indices of significance or importance in the data. By careful selection of features through the use of these attribute codes, one can control the amount of information displayed.

The minor codes in the 290 series are composed of four digits. The first digit indicates the category of data. The second digit is always zero. The last two digits both identify the feature in a generic sense and contain some index of significance. A description of the minor codes for each numeric series follows:

2000-2099: Hypsography. The only feature currently stored is the Continental Divide.

3000-3099: Streams. Examples of the features encoded include perennial, intermittent, and braided streams, and canals. In addition to the generic description, each feature is further categorized based on an approximate measure of overall feature length. In estimating the length of a feature, the path of a stream was determined by following the named (labeled) channel as far as possible, and then following the longest tributary.

4000-4099: Water Bodies. Examples of these features include perennial, intermittent, and dry lakes. Each feature is further classified by length along the longest dimension of the feature. 
5000-5069: Roads and Trails. Examples of these features include Interstate, U.S., and State highways. Each feature is further classified by such characteristics as length, access type (limited or non-limited access), proximity to a parallel route of a higher class, and as serving as a connector in a network of highways of a higher class.

5070-5080: Railroads. Railroads are classified based on a U.S. Department of Transportation classification scheme.

6000-6019: Political Boundaries. Classification is based on a hierarchical scheme of national, State, and county boundaries. Maritime boundary areas are usually closed by unattributed arbitrary extension lines and do not follow the shoreline.

6020-6099: Administrative Boundaries. Examples of these features include national parks, forests, wilderness areas, and Indian reservations. Each feature is further classified by length along the longest dimension of the feature.

7000-7099: Cultural Features (also referred to as Miscellaneous Transportation). Includes civilian and military airports and the Alaskan pipeline. Airports are only available in the standard and optional data distribution formats (refer to the Distribution format section).

An example of the use of these codes to control feature selection is illustrated in figures 2a through c. A map produced at a scale of 1:2,000,000 might include all streams from feature codes 3003 through 3016 and 3008 through 3030 (fig. 2a). A map at a scale of 1:5,000,000 might include streams with a length of greater than 50 kilometers (using feature codes 3007 through 3016 and 3021 through 3030) (fig. 2b).

Finally, at a scale of 1:10,000,000, a map might only display those features with a length greater than 100 kilometers (using codes 3010 through 3016 and 3024 through 3030) (fig. 2c).

These figures also illustrate the use of the "centerline in water body" codes (3035 through 3059). In generating a graphic of drainage for an area, normally data from both the stream and water body overlays is portrayed. When controlling the number of water bodies displayed in a graphic, it is possible that gaps will appear in a stream network where small bodies of water were not selected for display. The "centerline in water body" codes were meant to fill these gaps. For example, the codes were designed so that, if perennial lakes of length of 2 to less than 4 kilometers (code 4002) were not selected for display, the centerline in perennial lakes of 2 to less than 4 kilometers (code 3036) would be selected to maintain connectivity in the stream network. Unfortunately, these centerline codes only reference the body of water in which they reside and not the stream to which they are connected. It is possible that centerlines might be requested for display and the stream to which they connect not be selected for display.

\section{SAMPLE LINE GRAPH STRUCTURE}

Examples of a line graph and its corresponding digital records are given in figure 3 and table 2. These examples are simplified representations of the concepts used in the DLG-3 structure; they are not actual data files. The example shown is composed of 13 nodes, labeled N1 through N13, 5 areas, labeled A1 through A5, and 15 lines, labeled L1 through L15. Each element type is maintained as a separate list in the digital data. 


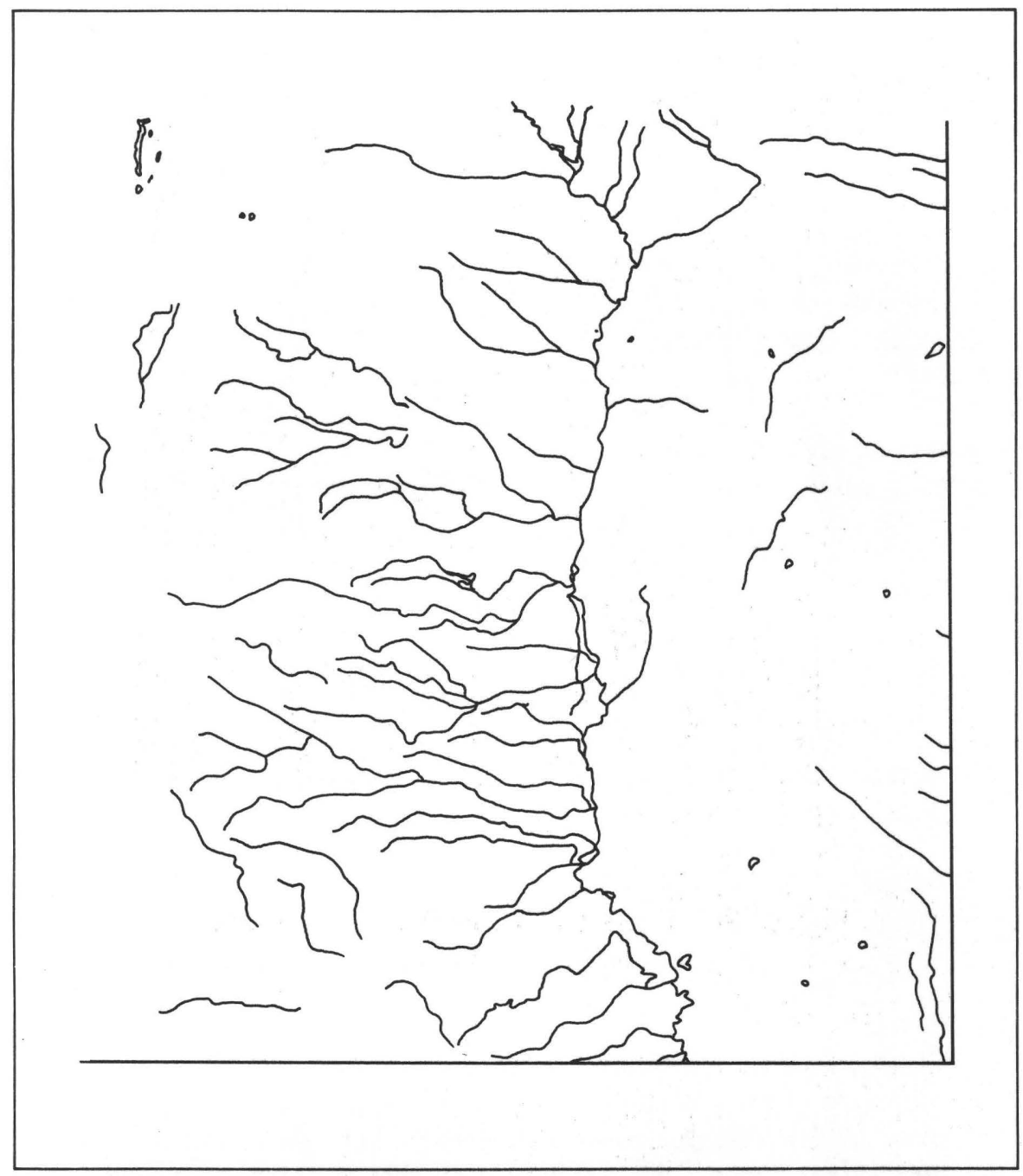

Figure 2a.--Pecos River, southeastern New Mexico.

Scale: $1: 2,000,000$.

The map represented by the example is divided into five distinct areas. Area $\mathrm{Al}$ represents the area outside of the map border. There is one outside area for each DLG-3. It is always the first area encountered and has the attribute code 0000000 . In the example given in figure 3, the portion of the map inside the border is divided into four areas, each bounded (closed) by lines. Area A2 is bounded by lines L14, L1, L4, and L5. Area A3 is bounded by lines L3, L13, L4, L6, L7, L8, L15, and L9. Area A4 is bounded by lines L8, L15, and L9. Area A5 is bounded by lines L5, L6, L7, and $\mathrm{L} 10$ and L2. 


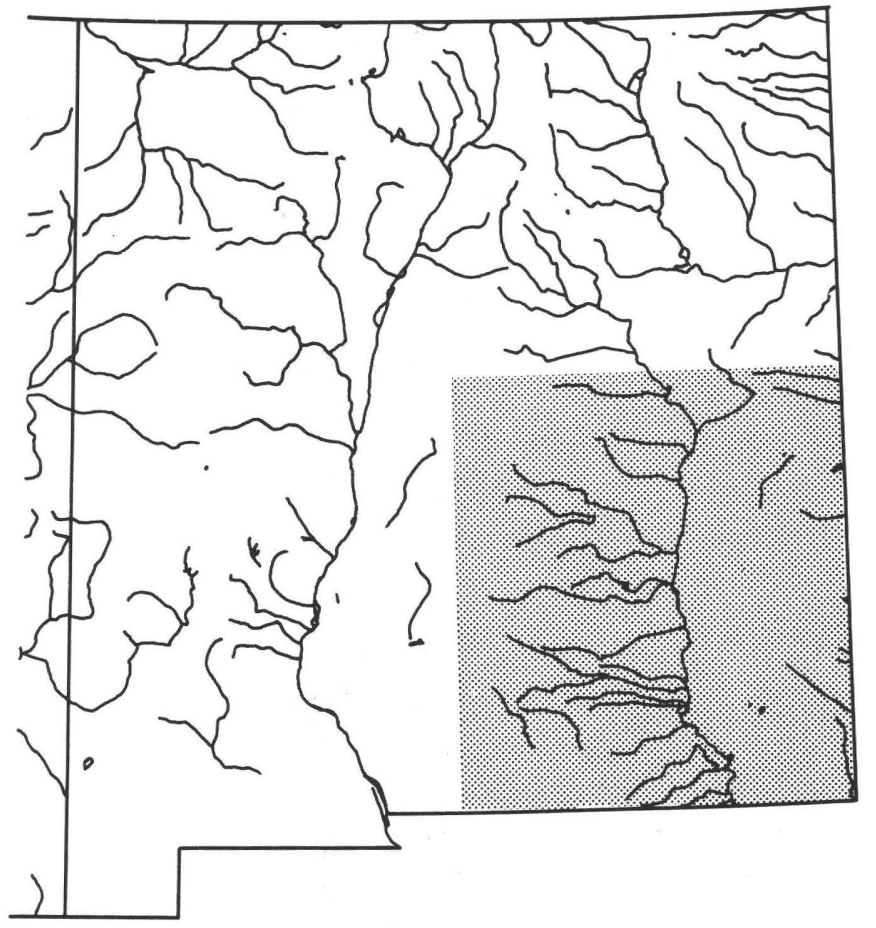

Figure 2b.--Rivers and water bodies, New Mexico.

Scale: $1: 5,000,000$.

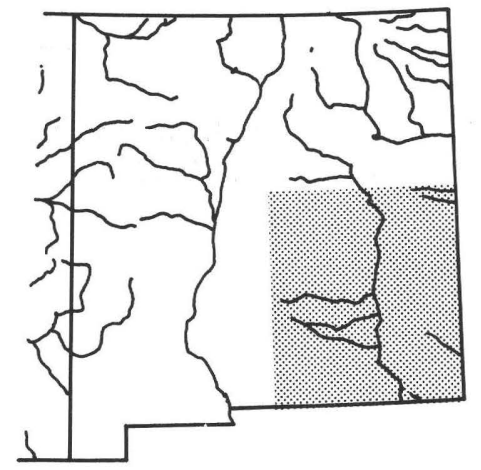

Figure 2c.--Rivers and water bodies, New Mexico.

Scale: 1:10,000,000.

In this example, line elements contain the only explicit topological references. Each line contains pointers to its bounding nodes (starting and ending) and the areas that it bounds (left and right of the line). This format is similar in concept to the standard DLG-3 data structure, which minimizes redundant linkages to achieve efficient data encoding and storage. 
The lines in figure 3 are labeled L1 through L15. The lines can be identified by their starting node number, ending node number, number of the area to the left of the direction of travel, number of the area to the right of the direction of travel, and string of coordinates describing the alignment of the line. In this example, only two pairs of coordinates are shown; however, in an actual file, an irregular line would have a variable number of coordinate pairs up to a limit of 1,500 coordinate pairs. The direction of travel of the line is arbitrarily determined during the digitizing operation. In this example, L1 is encoded as proceeding clockwise around area A2. Thus line L1 starts at node N1, ends at node N3, has area A1 to the left of the direction of travel, and has area A2 to the right of the direction of travel. The coordinate string describing the alignment of the line will start with the same coordinate values as that of node N1 and will end with the same coordinate values as that of node N3. Because the area to the left of its direction of travel, A1, is different from the area to the right of its direction of travel, A2, the line is known to be a boundary between the two areas.

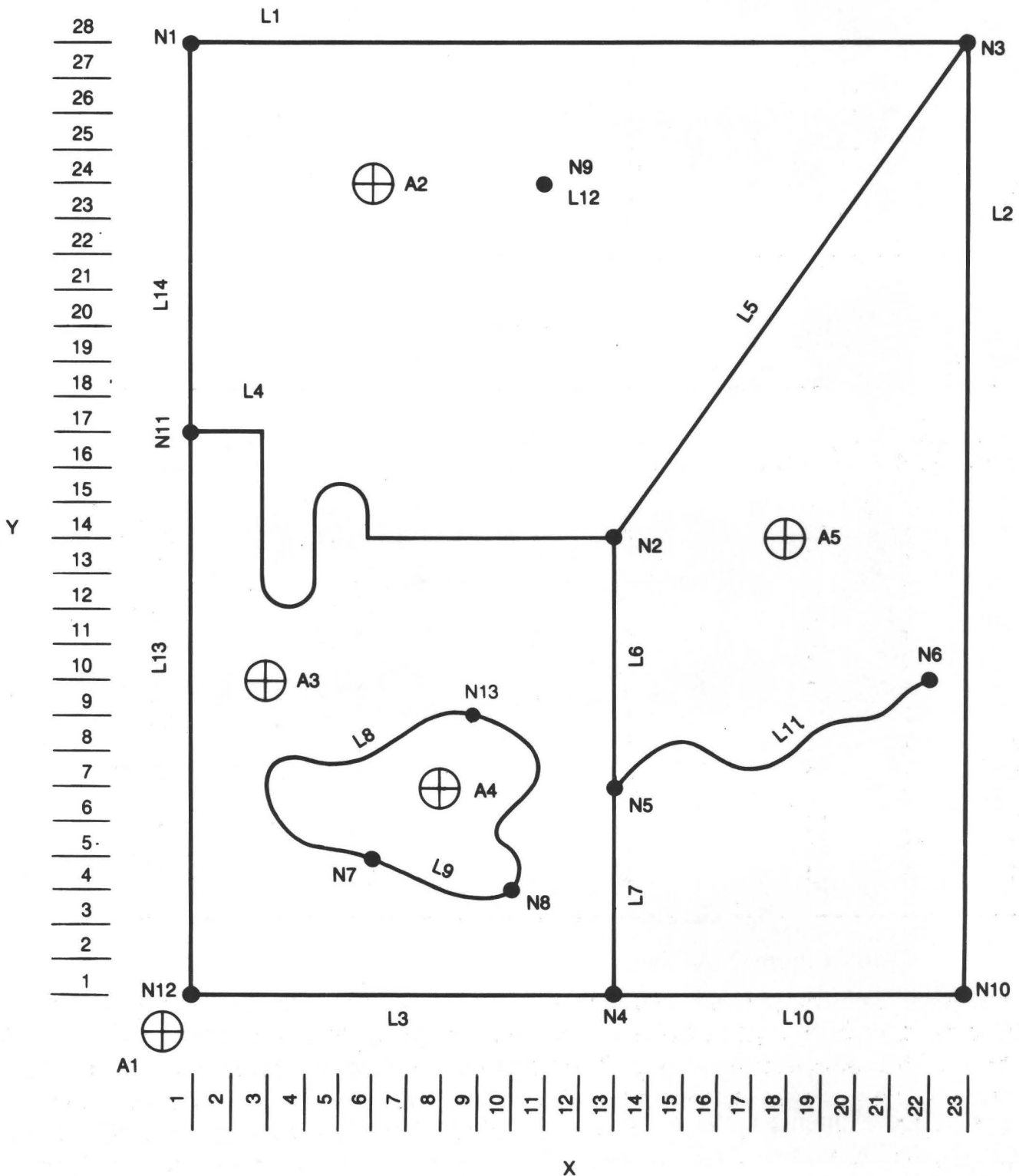

Figure 3.--Sample line graph. 
Table 2.--Description of the topological elements and relationships of a sample line graph (see fig. 3)

\begin{tabular}{|c|c|c|c|c|c|}
\hline \multicolumn{3}{|c|}{ Nodes } & \multicolumn{3}{|c|}{ Areas } \\
\hline $\begin{array}{l}\text { Internal } \\
\text { Id } \\
\text { Number } \\
\end{array}$ & $\mathrm{X}$ Coordinate & Y Coordinate & $\begin{array}{l}\text { Internal } \\
\text { Id } \\
\text { Number } \\
\end{array}$ & $\mathrm{X}$ Coordinate & Y Coordinate \\
\hline $\begin{array}{l}\text { N1 } \\
\text { N2 } \\
\text { N3 } \\
\text { N4 } \\
\text { N5 } \\
\text { N6 } \\
\text { N7 } \\
\text { N8 } \\
\text { N9 } \\
\text { N10 } \\
\text { N11 } \\
\text { N12 } \\
\text { N13 }\end{array}$ & $\begin{array}{r}1 \\
13 \\
23 \\
13 \\
13 \\
22 \\
6 \\
10 \\
11 \\
23 \\
1 \\
1 \\
9\end{array}$ & $\begin{array}{r}28 \\
14 \\
28 \\
1 \\
7 \\
10 \\
5 \\
4 \\
24 \\
1 \\
17 \\
1 \\
9\end{array}$ & $\begin{array}{l}\text { A1 } \\
\text { A2 } \\
\text { A3 } \\
\text { A4 } \\
\text { A5 }\end{array}$ & $\begin{array}{c}0 \\
6 \\
3 \\
8 \\
18\end{array}$ & $\begin{array}{r}0 \\
24 \\
10 \\
7 \\
14\end{array}$ \\
\hline
\end{tabular}

$\underline{\text { Lines }}$

\begin{tabular}{|c|c|c|c|c|c|c|c|}
\hline \multicolumn{3}{|c|}{ Nodes } & \multicolumn{2}{|c|}{ Area } & \multicolumn{3}{|c|}{ Coordinates } \\
\hline Number & Starting & Ending & $\overline{\text { Left }}$ & Right & (first $\mathrm{x} \mathrm{y}$ & & last $x(y)$ \\
\hline L1 & 1 & 3 & 1 & 2 & 1,28 & & 23,28 \\
\hline L2 & 3 & 10 & 1 & 5 & 23,28 & & 23,1 \\
\hline L3 & 4 & 12 & 1 & 3 & 13,1 & & 1,1 \\
\hline L4 & 11 & 2 & 2 & 3 & 1,17 & .... & 13,14 \\
\hline L5 & 2 & 3 & 2 & 5 & 13,14 & & 23,28 \\
\hline L6 & 2 & 5 & 5 & 3 & 13,14 & & 13,7 \\
\hline L7 & 5 & 4 & 5 & 3 & 13,7 & & 13,1 \\
\hline L8 & 13 & 7 & 4 & 3 & 9,9 & .... & 6,5 \\
\hline L9 & 7 & 8 & 4 & 3 & 6,5 & $\ldots$ & 10,4 \\
\hline L10 & 4 & 10 & 5 & 1 & 13,1 & & 23,1 \\
\hline L11 & 5 & 6 & 5 & 5 & 13,7 & $\ldots$ & 22,10 \\
\hline L12 & 9 & 9 & 2 & 2 & 11,24 & & 11,24 \\
\hline L13 & 12 & 11 & 1 & 3 & 1,1 & & 1,17 \\
\hline L14 & 11 & 1 & 1 & 2 & 1,17 & & 1,28 \\
\hline L15 & 8 & 13 & 4 & 3 & 10,4 & $\ldots$. & 9,9 \\
\hline
\end{tabular}

Lines L11 and L12 are examples of lines that lie within one area. In this example, line L11 starts at node N5, ends at node N6, has area A5 to the left of the direction of travel, and again has area A5 to the right of the direction of travel. The coordinate string for the line will start with the same coordinate values as that of node N5 and will end with the same coordinate value as that of node N6. Line L12 is an example of a degenerate line. The line starts at node N9, ends at node $\mathrm{N} 9$, and has area $\mathrm{A} 2$ as both the area to its left and right. There are only two coordinate pairs in 
the string defining the line: both points have the same coordinate values as node N9; thus, the two points are the same and the line has zero length.

The line graph concept allows all of the points on the map to be described as a member of a line graph element (node, area, or line) with minimal redundancy. The relationships between the various elements are indicated by the structure. Note that in this example the $\mathrm{x}$ and $\mathrm{y}$ coordinates are numbered from the lower left corner to simplify the drawing. In an actual DLG-3 file, the origin is the center of the map and the internal file coordinates are numbered plus or minus 1 to 32,767 expressed in thousandths of inches. See the section labeled "Coordinate Systems" for more detail.

\section{GRAPH THEORY IN DLG DATA}

There are two ways to implement the line graph concept in DLG files: the area case and the network case. These cases are differentiated by the nature of the information contained in the categories.

Area line graphs are used to represent areal features such as political entities or water bodies. Area line graphs correspond directly to the general line graph case in that each closed area on the map is represented by a distinct area element. Data categories that are collected as area line graphs include:

- $\quad$ Political Boundaries

- $\quad$ Administrative Boundaries

- Water Bodies

Network line graphs are used to represent linear features in digital form. The network case differs from the area case in that, irrespective of the number of closed areas forming the graph, only two area elements are encoded: (1) the area outside the graph, termed the outside area; and (2) the area within the graph, termed the background area. All lines except the graph boundary are considered to be contained within the background area. The major topological relationship expressed by network data is that of connectivity. Data encoded in network line graph form are suitable for various forms of network analysis, such as minimum path computations. Data categories that can be collected as network line graphs include:

$\begin{array}{ll}\text { - } & \text { Roads and Trails } \\ \text { - } & \text { Railroads } \\ \text { - } & \text { Cultural Features } \\ \text { - } & \text { Hypsography (Continental Divide only) }\end{array}$

In the area case, such as the boundary data collected from 1:2,000,000-scale maps, all areas on the graph have an identity pertinent to the category and are assigned attribute codes to describe them. The lines in such cases derive their significance from the areas they border. In the network case, as implemented in roads and trails collected from 1:2,000,000-scale maps, the lines themselves have the identity and are assigned attribute codes to describe them. The background area, represented by a single area record, does not have an attribute code assigned to it. 
Figure 4 shows a window in the vicinity of Catron County, New Mexico, taken from the Arizona and New Mexico 1:2,000,000-scale map. Figure 5 shows the line graph encoded for the boundaries of the same area. Certain nodes, areas, and lines are labeled.

Table 3 contains some of the digital data records extracted from the node, area, and line lists which describe this portion of the graph. (Note: Descriptions of DLG-3 formats are contained in Appendixes A, B, and C, and a list of attribute codes is contained in Appendix E.)

In the example, each node and area element is described by one or two logical records: (1) a type D. 1 record that describes the element, and (2) an optional type F record that lists the attribute codes associated with the element. The first record (type D.1) for each node and area element contains the following fields:

1. Type of record indicator, $\mathrm{N}$ for node or $\mathrm{A}$ for area.

2. Internal sequence identification number.

3. $\mathrm{x}$ coordinate of node or representative area point.

4. y coordinate of node or representative area point.

5. Number of attribute codes that describe the element.

6. Number of pairs of characters in the text string that describes the element.

The second record (type F) for each node and area element contains $\mathrm{n}$ attribute codes (expressed as major and minor code pairs), where $n$ is the number specified in field 5 of the first (type D.1) record.

Each line element in the example is described by two or three logical records: (1) a type D.2 line description record, and (2) a type $\mathrm{E}$ record that lists the $\mathrm{x}, \mathrm{y}$ coordinate pairs that define the shape of the line, and, if appropriate, (3) a type F (attribute code) record. The first record (type D.2) for each line element contains the following fields:

1. Type of record indicator (L).

2. Internal sequence identification number.

3. Internal sequence number of starting node.

4. Internal sequence number of ending node.

5. Internal sequence number of the area to the left of the line.

6. Internal sequence number of the area to the right of the line.

7. Number of $x, y$ coordinate pairs that locate the line on the map.

8. Number of attribute codes that describe the line.

9. Number of pairs of characters in the text string that describes the line.

The second logical record (type E) for each line element contains $\mathrm{n}$ coordinate pairs, where $\mathrm{n}$ is the number specified in field 7 of the first (type D.2) record. The type F record is as described above.

The topological pointers contained in the DLG-3 line elements enable a user to manipulate the data based on the spatial relationships. For example, some applications require areal data to be expressed as closed strings of $\mathbf{x , y}$ coordinate pairs. For such applications the user can request that the data be supplied in the optional distribution format. In this format the references to the boundary lines of each area are explicitly coded into the area record. For other applications the standard format may be preferable. 


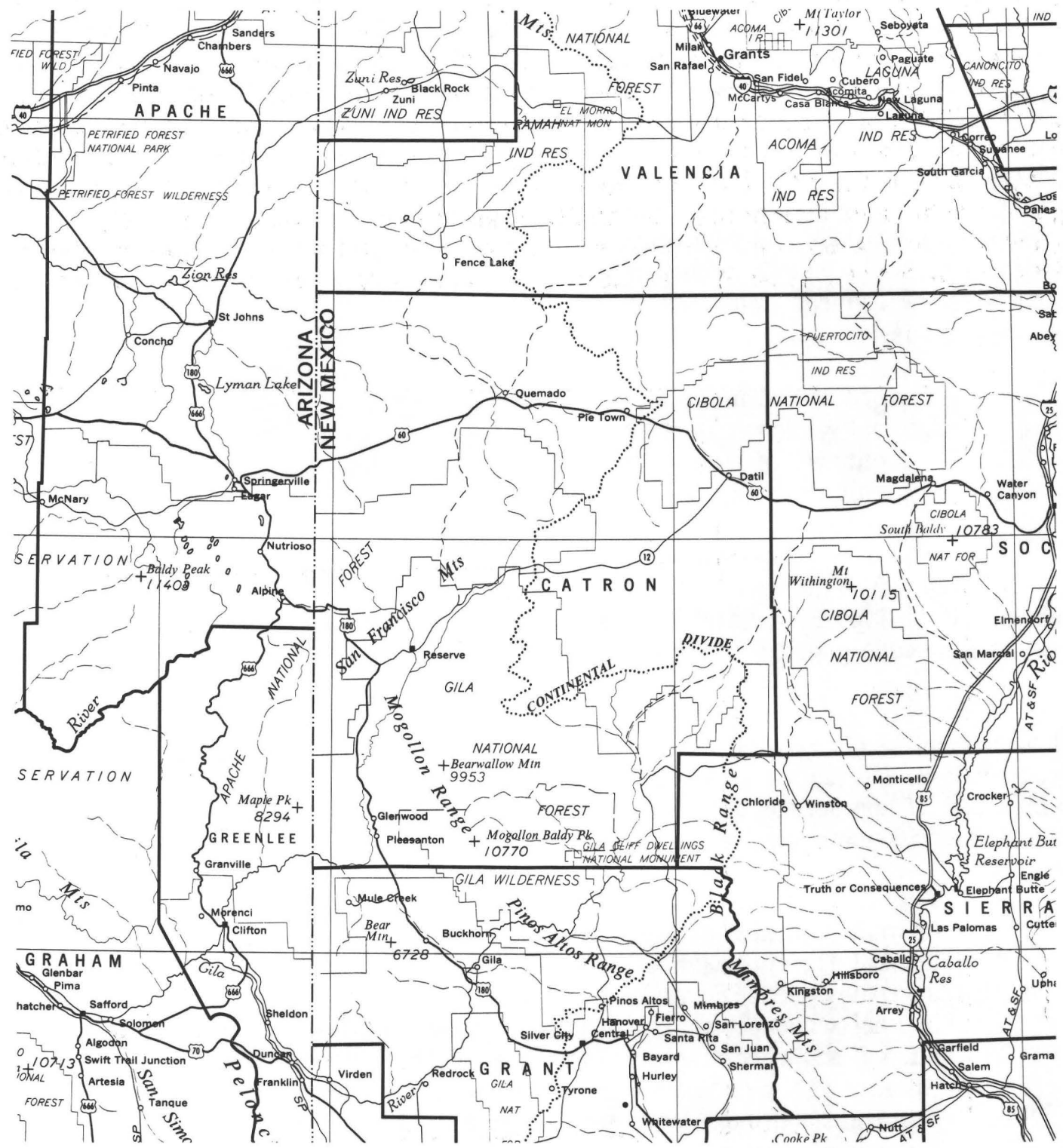

Figure 4.--Window from the Arizona-New Mexico, 1:2,000,000-scale sectional map of the National Atlas of the United States of America.

The specific records in table 3 describe Catron County, New Mexico. The county is described by 6 nodes, 1 area, and 6 lines. The area information, encoded in area record 10, includes the position of the area record (428, -934) and the attribute codes 0910035 and 0920003 identifying the area as being in the State of New Mexico and Catron County respectively. The boundary of the county is formed by lines $76,79,80,85,86$, and 87 . They can be verified as forming the boundary of this area by noting that each line has area 10 as the area to the left or right of the direction in which the line was digitized. In addition, the lines have attribute codes identifying them as portions of State boundaries (code 290 6005) or county boundaries (290 6009). The lines 
may be connected to form a closed loop around the area. This may be accomplished by reordering the line elements in a clockwise direction (where area 10 is always to the right of the direction of travel) or in a counterclockwise direction (where area 10 is always to the left of the direction of travel). (In reordering the direction of a line element, the starting node becomes the ending node (and vice versa), the area left becomes the area right (and vice versa), and the points describing the line are reordered (the first point becomes the last point, the second point becomes the second to the last point, etc.).) Once the lines are ordered correctly, the lines may be connected by using the starting and ending node information. Island-like features must be handled separately. Users whose applications will require this sort of structure should consider purchasing the optional format of the DLG data, which contains these forward and inverse pointers between lines and area and line and nodes.

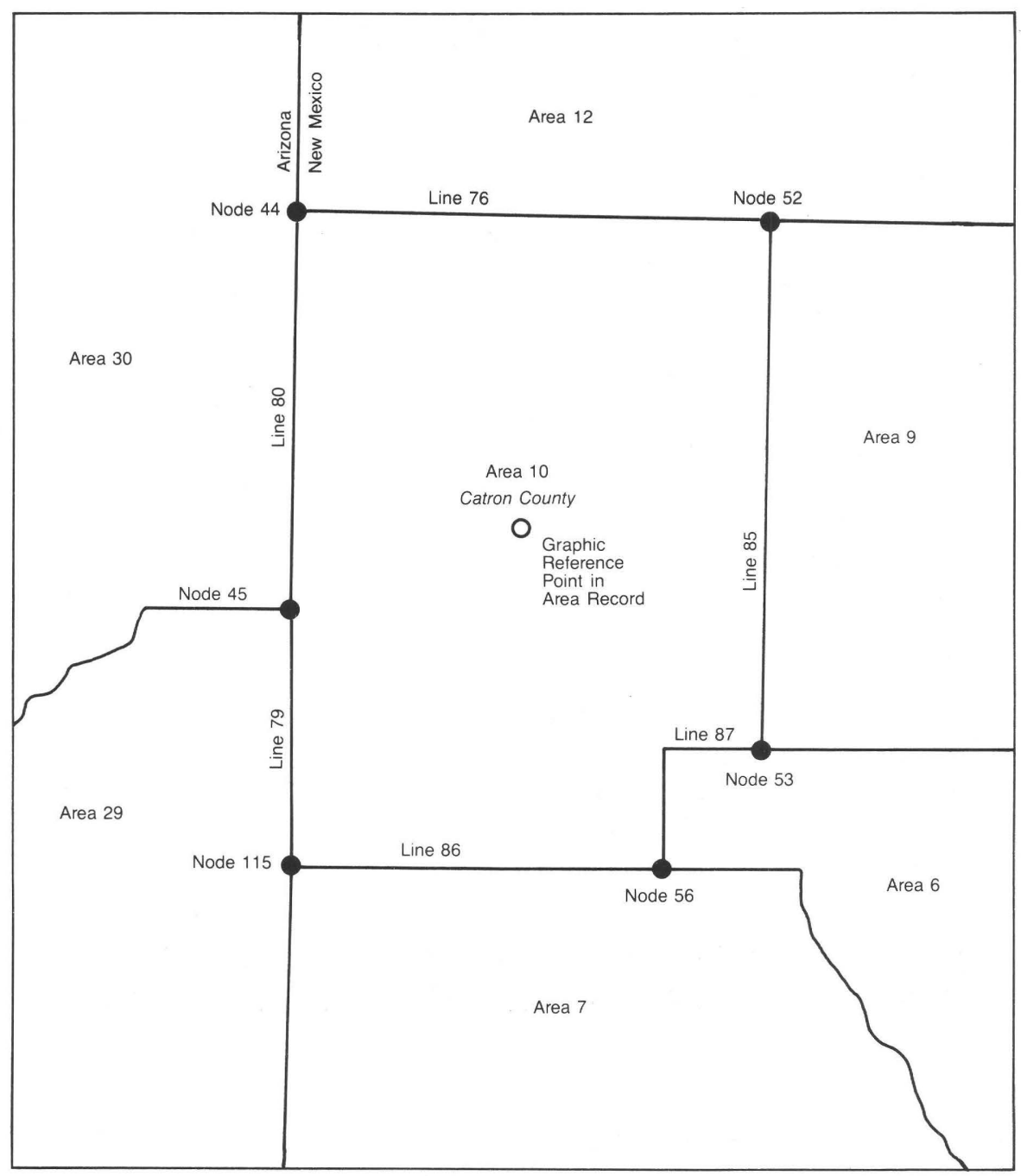

Figure 5.--Sample topology, Catron County, New Mexico. 
Table 3.--Selected sample of standard format DLG-3 records of Catron County, New Mexico [N, node; A, area; L, line]

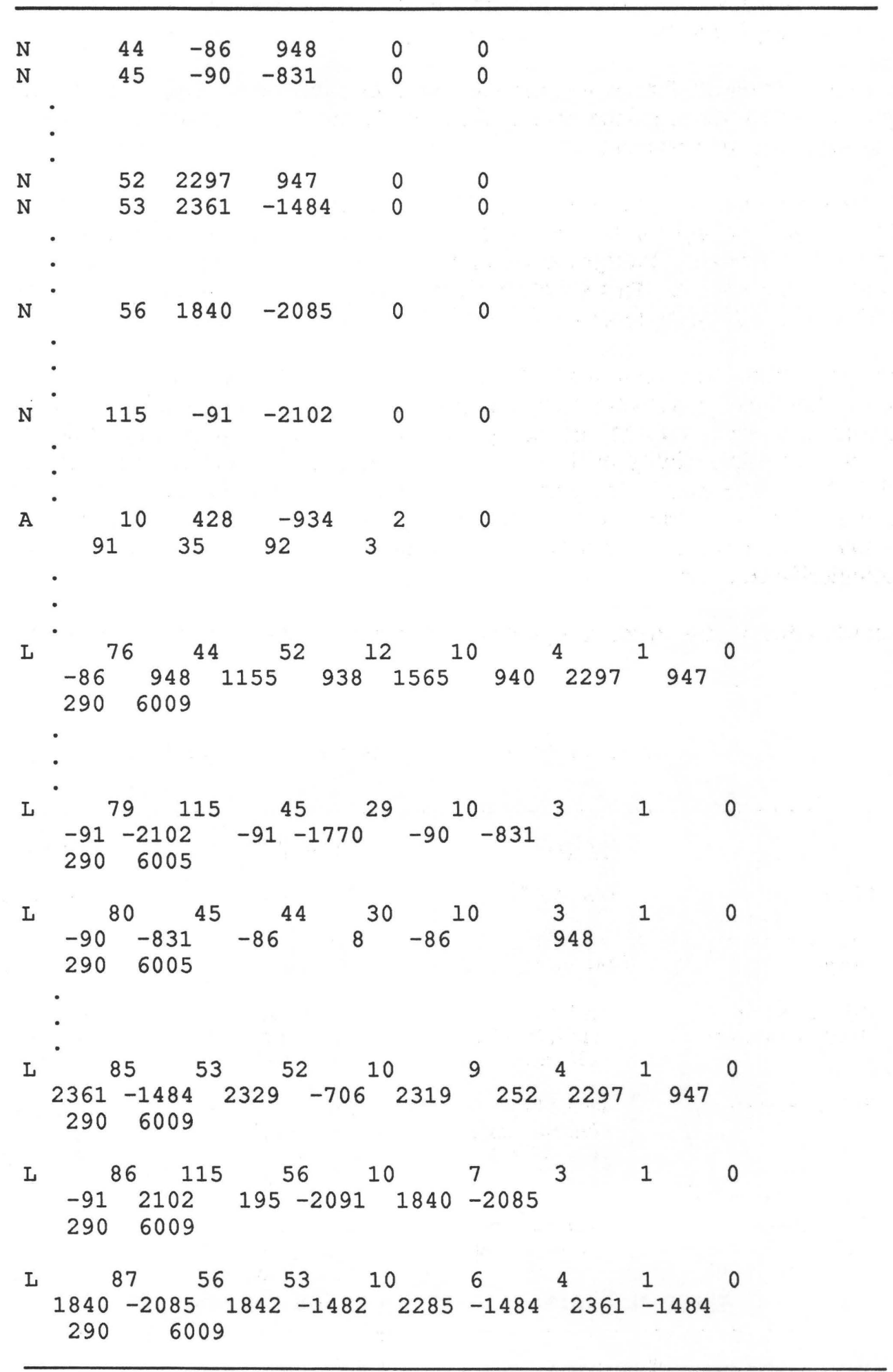




\section{DISTRIBUTION FORMATS}

The 1:2,000,000-scale DLG data are available in three distribution formats: (1) standard, (2) optional, and (3) graphic.

The standard distribution format was designed to minimize storage requirements. Explicit topological linkages are contained only in the line elements. A sample DLG data file in standard format is illustrated in Appendix G.

The optional distribution format was designed for data interchange. These files are typically larger than those in the standard format but, for certain applications, can simplify processing requirements. Topological linkages are explicitly encoded between all line and node elements, and all line and area elements. This structure allows a polygon data structure to be easily created. A sample DLG data file in optional format is illustrated in Appendix $\mathrm{H}$.

The graphic distribution format was designed to be compatible with the GS-CAM (Geological Survey - Cartographic Automatic Mapping) software. This software provides for plotting line and point information using a variety of map projections, scales, and graphic symbologies. To obtain information on the availability of the GS-CAM software, please refer to the inside front cover of this publication. The files in the graphic distribution format are derived from the topologically structured DLG data described above, and contain a subset of the line and attribute code information in the DLG files. No node or area information is stored in these files. These files are not topologically structured.

The characteristics of the standard, optional, and graphic DLG formats are summarized in table 4.

Table 4.--Standard, optional, and graphic DLG format

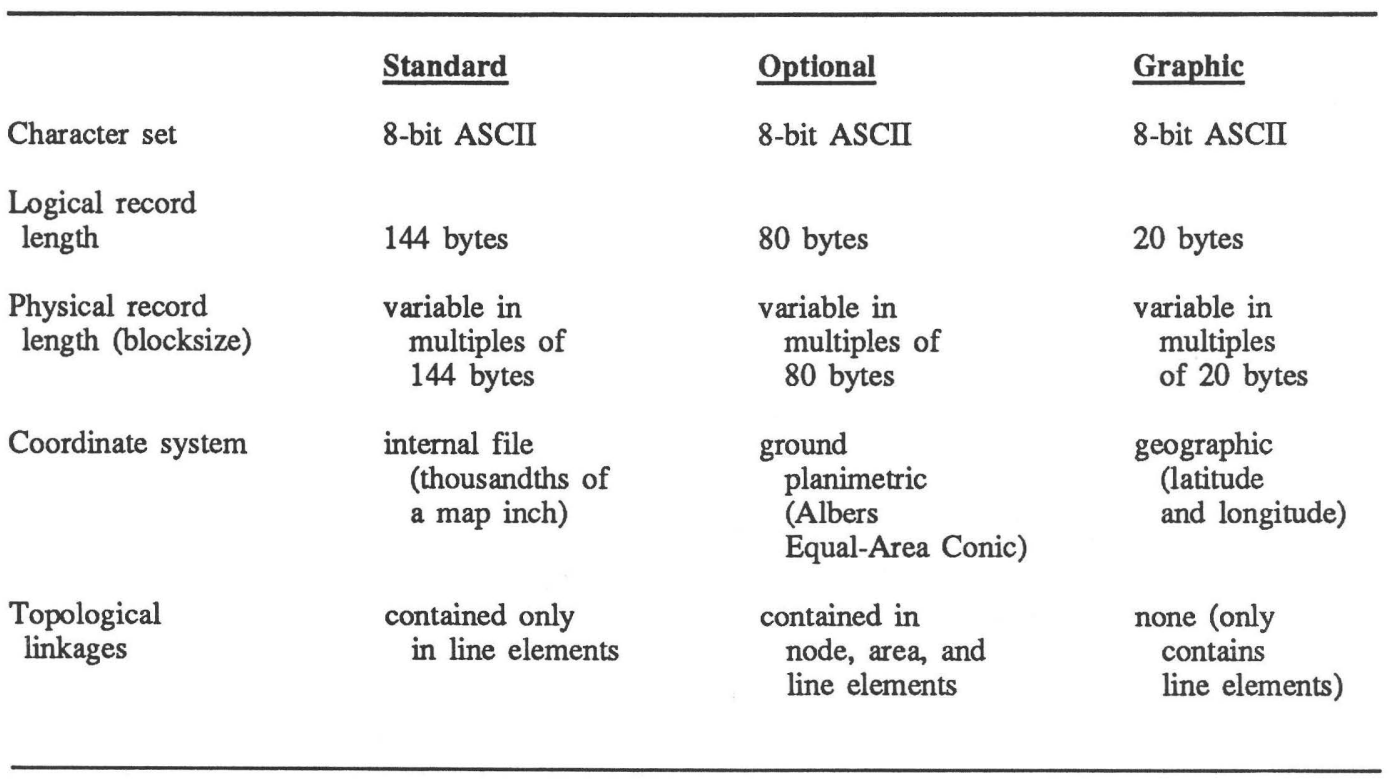

These formats are described in detail in Appendixes A, B, and C. 


\section{SOURCE MATERIALS}

The data described in this document are derived from USGS 1:2,000,000-scale reference maps from The National Atlas of the United States of America. Selective updating of the maps was done prior to digitizing. Data source and currency information may be found in Appendix I.

The data for the conterminous United States and Hawaii were collected from 1:2,000,000-scale map manuscripts. For Alaska, the boundary and transportation data were digitized from 1:2,000,000scale source documents; the hydrographic data were digitized from 1:1,000,000-scale source documents. The scale of the source materials used to generate a DLG is contained in the file header. The scale is also reflected in the resolution field, which states the ground length in meters of the smallest data collection unit 0.001 inch (50.8 meters for 1:2,000,000-scale data; 25.4 meters for $1: 1,000,000$-scale data).

\section{CELL SIZE AND FILE EXTENT}

The DLG's are distributed predominantly in multistate cells (fig. 6). There are a total of 21 cells for the United States: 15 for the conterminous United States, 5 for Alaska, and 1 for Hawaii. In general, States are not divided between cells. Three States (California, Texas, and Montana) are divided between two cells along county boundaries. Alaska is divided among five cells along arcs of longitude and/or latitude.

The data for each cell are encoded in multiple thematic categories (Political Boundaries, Administrative Boundaries, Roads and Trails, Railroads, Cultural Features, Streams, Water Bodies, and (where appropriate) Hypsography). Normally, there is one file per category. Due to software limitations at the time of digitizing, however, some categories with a large number of elements may be encoded in several files. Files are not horizontally integrated (edge joined) between cells.

\section{COORDINATE SYSTEMS}

The positional descriptions for DLG data elements are expressed in one of three coordinate systems, dependent upon the distribution format selected. These distribution formats - standard, optional, and graphic - are described below.

\section{$\underline{\text { Standard Distribution Format }}$}

The DLG data in the standard distribution format are encoded using an internal file coordinate system to minimize storage requirements. The characteristics of this system are as follows:

1. The coordinate system is Cartesian.

2. The origin $(x=0, y=0)$ is at the center of the cell (fig. 7).

3. The $\mathrm{x}$-axis of the coordinate system is parallel to a theoretical straight line connecting the southwest and southeast registration points of the cell, y-axis is perpendicular to that line.

4. One unit is equal to 0.001-inch at map scale.

5. The coordinate domain is limited to the range -32768 to +32767 . 


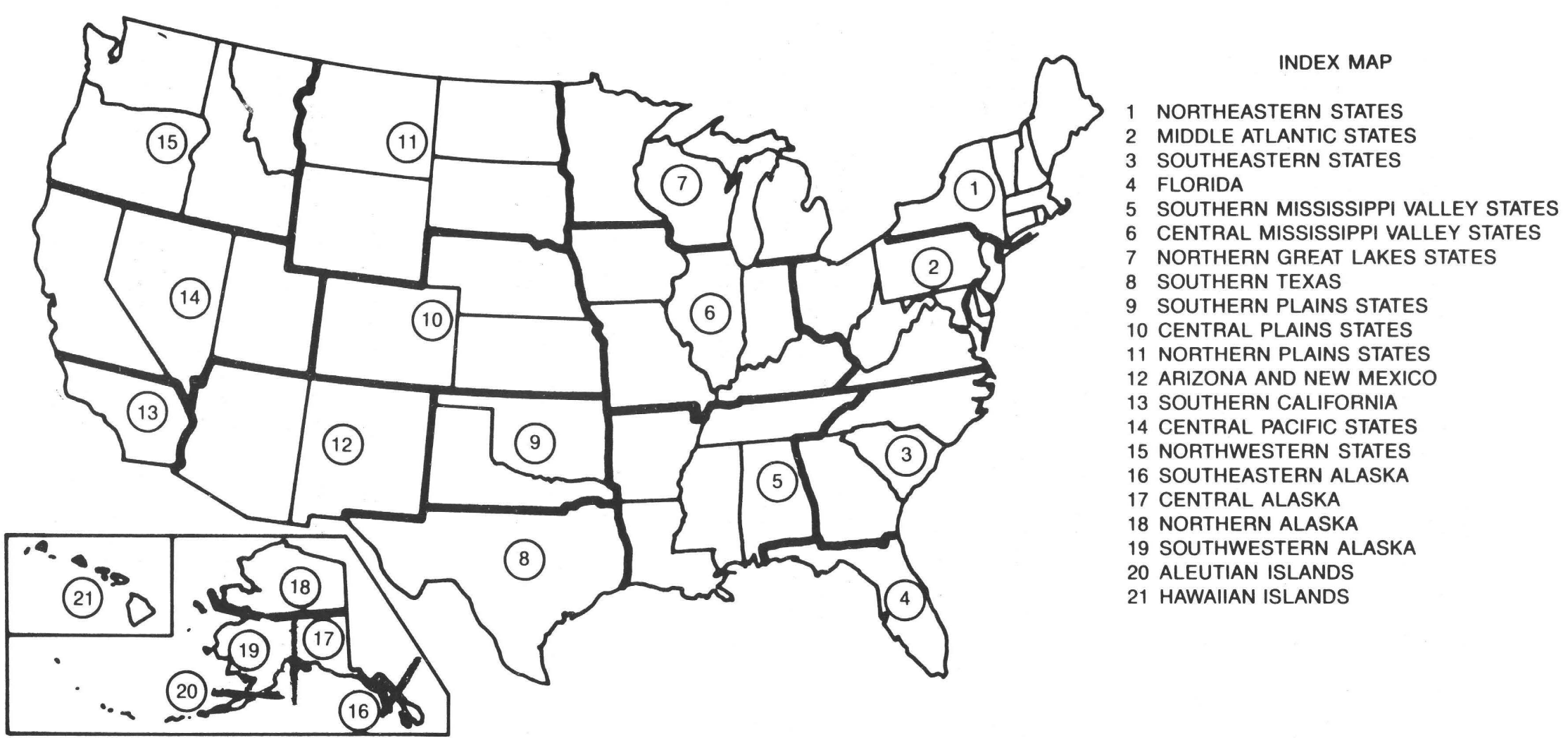

Figure 6.--Multistate cells used for Digital Line Graphs from 1:2,000,000-scale maps. 


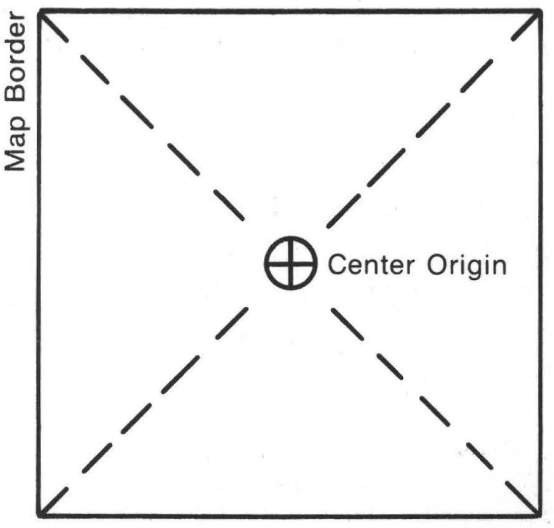

Figure 7.--Location of origin of file reference coordinates.

The file header contains the parameters of a transformation which can be used to convert the internal file coordinates to the ground coordinate system, which is the Albers Equal-Area Conic Projection for 1:2,000,000-scale DLG's. An example of this transformation is given in Appendix F.

\section{Optional Distribution Format}

The DLG data in the optional distribution format are expressed in the units of the ground coordinate system, that is, meters in the Albers Equal-Area Conic coordinate systems described in Appendix D.

\section{Graphic Distribution Format}

The data in the graphic distribution format are expressed in geographic coordinates (latitudelongitude). These values are expressed in degrees-minutes-seconds.

\section{DATA VALIDATION}

The DLG data do not currently carry quantified accuracy statements. The following procedures, however, are used to validate the data files before they are released for distribution:

1. File fidelity and completeness -- The data are manually digitized using equipment with a resolution of 0.001 inch and an absolute accuracy of from 0.003 to 0.005 inch. The positional accuracy of the data and completeness of the file are checked by visually comparing proof plots with the original stable-base source material. These proof plots are generated using automated drafting machines with a resolution of 0.001 inch and an absolute accuracy of from 0.003 to 0.005 inch. 
2. Attribute accuracy -- Validating the codes for correct application is currently a manual process involving the correlation of formatted listings with proof plots.

3. Topological fidelity -- The topological structure of each DLG file is fully validated by software. There are no extraneous intersections; that is, a line does not join or cross another line, or itself, except at a node. No line extends through a node. Polygon (area) adjacency is also validated; that is, area left and right topological attributes of lines are consistent throughout the file. The neatline is free of gaps. Validation of DLG data is performed for each category within a file.

[Note: A deficiency in the topological validation software was discovered after the data were processed. For some graphic representations the software did not check the topology of island-like features correctly; some features of this type may have incorrect topology in the files.] 



\section{APPENDIXES}





\section{APPENDIX A.--Standard DLG Distribution Format (Record Contents)}

In the standard DLG distribution format, the topological linkages are contained only in the line elements. The files are physically comprised of standard 8-bit ASCII characters organized into fixed-length logical records of 144 characters. Nine distinct record types are defined.

\section{Logical \\ record \\ type}

The actual sequence of records in a standard distribution DLG file is as follows:

1. Header records

Type A (one record)

Type B (one record)

Type C (one record)

2. Data records

\section{Content}

Header record containing DLG identification information.

Header record containing projection information and registration points. number of nodes, areas, and lines in each category.

D.1 A node or an area record.

E Record containing $\mathrm{x}, \mathrm{y}$ coordinate string.

Record containing attribute codes.

Accuracy estimate (not currently used).

Node records

Node description (D.l)

Attribute codes (F)

Text string $(\mathrm{G})$

\section{Area records}

Area description (D.1)

Attribute codes (F)

Text string $(\mathrm{G})$

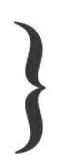

Repeated

for each

node within a

data category

Repeated

for each

area within a

data category

Line records

Line description (D.2)

$\mathrm{x}, \mathrm{y}$ coordinates $(\mathrm{E})$

Attribute codes (F)

Text string (G)

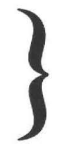

\}
Repeated

for each

line within a

data category
Repeated

for each

data category

3. Accuracy estimate

Type H (one record) (not currently used)

Descriptions of the contents of records A-F are contained in the following tables. The tables also reflect the relationship between these record types and 144-byte logical records. 
APPENDIX A.--Standard DLG Distribution Format (Record Contents)--continued

[Integer fields with a value of zero will have leading zeros suppressed. For example, an I6 field would be "bbbbbo". $(b=b l a n k)]$

[Any field with the format of D24.15 which has a value of zero will be

represented as "bbb0.0bbbbbbbbbbbbbbbbbb", the last four

positions of the fractional portion being reserved for a

decimal exponent. $\quad(\mathrm{b}=\mathrm{blank})]$

\begin{tabular}{|c|c|c|c|c|c|c|c|}
\hline $\begin{array}{l}\text { Record } \\
\text { Number } \\
\end{array}$ & $\begin{array}{l}\text { Data } \\
\text { Element }\end{array}$ & Contents & $\begin{array}{c}\text { Type } \\
\text { (Fortran Notation) }\end{array}$ & Format & $\begin{array}{l}\text { Starting } \\
\text { Byte }\end{array}$ & $\begin{array}{l}\text { Ending } \\
\text { Byte }\end{array}$ & Comment \\
\hline A.I & 1 & $\begin{array}{l}\text { Name of digital } \\
\text { cartographic unit }\end{array}$ & ALPHA & $\mathrm{A} 40$ & 1 & 40 & $\begin{array}{l}\text { The name of the map will be } \\
\text { used when practical. }\end{array}$ \\
\hline-- & --- & Filler & --- & --- & 41 & 41 & I space \\
\hline A. 1 & 2 & $\begin{array}{l}\text { Date of original } \\
\text { source materials }\end{array}$ & ALP HA & Alo & 42 & 51 & $\begin{array}{l}\text { Year of original source } \\
\text { material, followed by latest } \\
\text { revision date if applicable, } \\
\text { for example, 1956, } 1965 \text {. }\end{array}$ \\
\hline-- & -- & Filler & -- & --- & 52 & 52 & I space \\
\hline A. 1 & 3 & $\begin{array}{l}\text { Scale of original } \\
\text { source material }\end{array}$ & INTEGER * 4 & I8 & 53 & 60 & $\begin{array}{l}\text { Scale denominator of source } \\
\text { material, for example, } \\
2000000 \text {. }\end{array}$ \\
\hline--- & --- & Filler & -- & --- & 61 & 144 & 84 spaces \\
\hline A. 2 & 1 & DLG level code & INTEGER *2 & I6 & 1 & 6 & Code $=3$, DLG -3 \\
\hline A. 2 & 2 & $\begin{array}{l}\text { Code defining } \\
\text { ground planimetric } \\
\text { reference system }\end{array}$ & INTEGER *2 & I6 & 7 & 12 & $\begin{array}{l}\text { Code }=3 \text {, Albers Equal-Area } \\
\text { Conic projection }\end{array}$ \\
\hline A. 2 & 3 & $\begin{array}{l}\text { Code defining zone } \\
\text { in ground plan- } \\
\text { imetric reference } \\
\text { system }\end{array}$ & INTEGER *2 & I6 & 13 & 18 & Code $=9999$ \\
\hline
\end{tabular}


APPENDIX A.--Standard DLG Distribution Format (Record Contents)--continued

\begin{tabular}{|c|c|c|c|c|c|c|c|}
\hline $\begin{array}{l}\text { Record } \\
\text { Number } \\
\end{array}$ & $\begin{array}{l}\text { Data } \\
\text { Element }\end{array}$ & Contents & $\begin{array}{l}\text { Type } \\
\text { tran Notation) }\end{array}$ & Format & $\begin{array}{l}\text { Starting } \\
\text { Byte }\end{array}$ & $\begin{array}{l}\text { Ending } \\
\text { Byte }\end{array}$ & Comment \\
\hline A. 2 & 4 & $\begin{array}{l}\text { Map projection } \\
\text { parameters }\end{array}$ & $\mathrm{REAL} \star 8$ & $5 \mathrm{D} 24.15$ & 19 & 138 & $\begin{array}{l}\text { This field contains the } \\
\text { first } 5 \text { of } 15 \text { map projection } \\
\text { parameters. Parameters } \\
\text { for the Albers Equal-Area } \\
\text { Conic projection are given } \\
\text { in Appendix D. }\end{array}$ \\
\hline--- & --- & Filler & --- & --- & 139 & 144 & 6 spaces \\
\hline A. 3 & 1 & $\begin{array}{l}\text { Map projection } \\
\text { parameters }\end{array}$ & REAL $\star 8$ & $6 \mathrm{D} 24.15$ & 1 & 144 & $\begin{array}{l}\text { This record contains } \\
\text { projection parameters } 6 \\
\text { thru ll. Parameters for the } \\
\text { Albers Equal-Area Conic } \\
\text { projection are given } \\
\text { in Appendix D. }\end{array}$ \\
\hline A. 4 & 1 & $\begin{array}{l}\text { Map projection } \\
\text { parameters }\end{array}$ & REAL $* 8$ & $4 \mathrm{D} 24.15$ & 1 & 96 & $\begin{array}{l}\text { This field contains the } \\
\text { last } 4 \text { projection } \\
\text { parameters. Parameters for } \\
\text { the Albers Equal-Area Conic } \\
\text { projection are given } \\
\text { in Appendix D. }\end{array}$ \\
\hline A. 4 & 2 & $\begin{array}{l}\text { Code defining units of } \\
\text { measure for ground } \\
\text { planimetric coordinates } \\
\text { throughout the file }\end{array}$ & INTEGER $* 2$ & I6 & 97 & 102 & Code $=2$, meters \\
\hline A. 4 & 3 & Resolution & REAL $\star 8$ & $\mathrm{D} 24.15$ & 103 & 126 & $\begin{array}{l}\text { The true ground distance } \\
\text { corresponding to one unit } \\
(0.001 \text { inch at map scale) in } \\
\text { the file internal reference } \\
\text { system. For } 1: 2,000,000- \\
\text { scale } 0.001 \text { inch equals } 50.8 \\
\text { meters. }\end{array}$ \\
\hline
\end{tabular}


APPENDIX A.--Standard DLG Distribution Format (Record Contents)--continued

\begin{tabular}{|c|c|c|c|c|c|c|c|}
\hline $\begin{array}{l}\text { Record } \\
\text { Number }\end{array}$ & $\begin{array}{l}\text { Data } \\
\text { Element }\end{array}$ & Contents & $\begin{array}{c}\text { Type } \\
\text { Fortran Notation) }\end{array}$ & Format & $\begin{array}{l}\text { Starting } \\
\text { Byte }\end{array}$ & $\begin{array}{l}\text { Ending } \\
\text { Byte }\end{array}$ & Comment \\
\hline A. 4 & 4 & $\begin{array}{l}\text { Accuracy code of } \\
\text { planimetric data }\end{array}$ & INTEGER *2 & I 6 & 127 & 132 & Code $=0$, unknown accuracy \\
\hline A. 4 & 5 & $\begin{array}{l}\text { Number }(n) \text { of } \\
\text { registration points }\end{array}$ & INTEGER *2 & I6 & 133 & 138 & $\mathrm{n}=4$ \\
\hline--- & --- & Filler & --- & --- & 139 & 144 & 6 spaces \\
\hline $\begin{array}{l}\text { A. } 5 \\
\text { A. } 6\end{array}$ & 1 & $\begin{array}{l}\text { A }(4,2) \text { array contain- } \\
\text { ing geographic } \\
\text { coordinates of the } \\
\text { registration points }\end{array}$ & REAL * 8 & $\begin{array}{l}3(2 \mathrm{D} 24.15) \\
2 \mathrm{D} 24.15\end{array}$ & $\begin{array}{l}1 \\
1\end{array}$ & $\begin{array}{l}144 \\
48\end{array}$ & $\begin{array}{l}\text { Coordinates are in } \\
\text { geographic longitude and } \\
\text { latitude in units of } \\
\text { degrees and decimal } \\
\text { degrees and are expressed } \\
\text { in the order=SW, NW, NE, SE. }\end{array}$ \\
\hline-- & --- & Filler & --- & --- & 49 & 144 & 96 spaces \\
\hline
\end{tabular}


APPENDIX A.--Standard DLG Distribution Format (Record Contents)--continued

\begin{tabular}{|c|c|c|c|c|c|c|c|}
\hline $\begin{array}{l}\text { Record } \\
\text { Number } \\
\end{array}$ & $\begin{array}{l}\text { Data } \\
\text { Element }\end{array}$ & Contents & $\begin{array}{l}\text { Type } \\
\text { tran Notation) }\end{array}$ & Format & $\begin{array}{l}\text { Starting } \\
\text { Byte }\end{array}$ & $\begin{array}{l}\text { Ending } \\
\text { Byte }\end{array}$ & Comment \\
\hline B. 1 & 1 & $\begin{array}{l}\text { Parameters (Al, A2, } \\
\text { A3, A4) of file- } \\
\text { to-ground projection } \\
\text { transformation; the } \\
\text { explicit form of the } \\
\text { transformation is: } \\
X=A l x+A 2 y+A 3 \\
Y=A l y-A 2 x+A 4 \\
\text { where: } \\
x, y \text { are coordinates in } \\
\text { file internal reference } \\
\text { system } X, Y \text { are coor- } \\
\text { dinates in map projec- } \\
\text { tion reference system }\end{array}$ & REAL * 8 & $4 \mathrm{D} 24.15$ & 1 & 96 & $\begin{array}{l}\mathrm{X}, \mathrm{Y} \text { coordinates resulting } \\
\text { from this transformation } \\
\text { will be in ground meters in } \\
\text { the Albers Equal-Area Conic } \\
\text { projection coordinate system } \\
\text { defined by the data elements } \\
\text { in records } \mathrm{A} .2 \text { - A.4. }\end{array}$ \\
\hline B.I & 2 & $\begin{array}{l}\text { Number }(\mathrm{m}) \text { of regis- } \\
\text { tration points }\end{array}$ & INTEGER *2 & I6 & 97 & 102 & $\mathrm{~m}=4$ \\
\hline-- & -- & Filler & -- & -- & 103 & 144 & 42 spaces \\
\hline
\end{tabular}


APPENDIX A.--Standard DLG Distribution Format (Record Contents)--continued

Logical Record Type B--continued

\begin{tabular}{|c|c|c|c|c|c|c|c|c|}
\hline $\begin{array}{l}\text { Record } \\
\text { Number } \\
\end{array}$ & $\begin{array}{l}\text { Data } \\
\text { Element }\end{array}$ & Contents & $\begin{array}{l}\text { Type } \\
\text { ran Notation) }\end{array}$ & Format & & $\begin{array}{l}\text { Starting } \\
\text { Byte }\end{array}$ & $\begin{array}{l}\text { Ending } \\
\text { Byte }\end{array}$ & Comment \\
\hline B. 2 & 1 & $\begin{array}{l}\text { A }(4,3) \text { array con- } \\
\text { taining identifications } \\
\text { and coordinates of } \\
\text { registration points. } \\
\text { Coordinates are } \\
\text { expressed in the file } \\
\text { internal reference } \\
\text { system }\end{array}$ & $\begin{array}{l}\text { ALPHA/ } \\
\text { INTEGER *2 }\end{array}$ & 4 (A), & $2 I 6)$ & 1 & 56 & $\begin{array}{l}\text { The corners of a four-sided } \\
\text { polygon are used as } \\
\text { registration points. The } \\
\text { identification sequence is } \\
\text { SW, NW, NE, SE. The array } \\
\text { is stored by row. } \\
\text { Coordinates in the file } \\
\text { internal reference system } \\
\text { are expressed in units of } \\
\text { thousandths of an inch and } \\
\text { fall in the range - } 32768 \text { to } \\
\text { +32767. These coordinates } \\
\text { correspond to the geographic } \\
\text { coordinates contained in } \\
\text { records A.5 and A.6. }\end{array}$ \\
\hline-- & --- & Filler & --- & --- & & 57 & 144 & 88 spaces \\
\hline
\end{tabular}


APPENDIX A.--Standard DLG Distribution Format (Record Contents)--continued

\begin{tabular}{|c|c|c|c|c|c|c|c|}
\hline $\begin{array}{l}\text { Record } \\
\text { Number } \\
\end{array}$ & $\begin{array}{l}\text { Data } \\
\text { Element }\end{array}$ & Contents & $\begin{array}{l}\text { Type } \\
\text { ran Notation) }\end{array}$ & Format & $\begin{array}{l}\text { Starting } \\
\text { Byte }\end{array}$ & $\begin{array}{l}\text { Ending } \\
\text { Byte }\end{array}$ & Comment \\
\hline C.I & 1 & $\begin{array}{l}\text { Number (q) of } \\
\text { categories } \\
\text { in the DLG file }\end{array}$ & INTEGER * 4 & I6 & 1 & 6 & $\begin{array}{l}1 \leq q \leq 32 \text {. Up to } 32 \text { categories } \\
\text { can be represented in a } \\
\text { given file, however, all } \\
1: 2,000,000-\text { scale data } \\
\text { files include only one. }\end{array}$ \\
\hline--- & --- & Filler & -- & --- & 7 & 144 & 138 spaces \\
\hline $\begin{array}{l}\text { C. } 2^{1} \\
\text { to C.N }\end{array}$ & 1 & $\begin{array}{l}\text { A }(q, 7) \text { array contain- } \\
\text { ing category names as } \\
\text { well as maximum and } \\
\text { actual number of node, } \\
\text { area, and line elements } \\
\text { in each category }\end{array}$ & $\begin{array}{l}\text { ALPHA/ } \\
\text { INTEGER } 2\end{array}$ & $q(A 20,6 I 6)$ & $\begin{array}{l}1 \\
157\end{array}$ & $\begin{array}{c}56 \\
112)\end{array}$ & $\begin{array}{l}\text { This array is stored by } \\
\text { row. The first element is } \\
\text { the category name consisting } \\
\text { of } 20 \text { alphanumeric characters, } \\
\text { the first four of which are } \\
\text { unique. Columns } 2 \text { and } 3 \text { of } \\
\text { the array contain maximum and } \\
\text { actual number of nodes in the } \\
\text { category. Columns } 4 \text { and } 5 \\
\text { contain maximum and actual } \\
\text { number of areas in the cate- } \\
\text { gory. Columns } 6 \text { and } 7 \text { are } \\
\text { the maximum and actual number } \\
\text { of line segments. (Note: the } \\
\text { maximum number of any element } \\
\text { type within a category is } \\
4,770 \text {. This field is used only } \\
\text { during initial processing of } \\
\text { data). }\end{array}$ \\
\hline-- & --- & Filler & -- & --- & -- & --- & 32 or 88 spaces \\
\hline
\end{tabular}

${ }^{1}$ The number of categories "q" is given in record c.1. There will be 56 bytes of data per category, and thus a maximum of two categories can be described on a 144-character record. The space filler will vary in size depending on the value of "q." 
APPENDIX A.--Standard DLG Distribution Format (Record Contents)--continued

\begin{tabular}{|c|c|c|c|c|c|c|c|}
\hline $\begin{array}{l}\text { Record } \\
\text { Number }\end{array}$ & $\begin{array}{l}\text { Data } \\
\text { Element }\end{array}$ & (Fort) & $\begin{array}{l}\text { Type } \\
\text { Eran Notation) }\end{array}$ & Format & $\begin{array}{l}\text { Starting } \\
\text { Byte }\end{array}$ & $\begin{array}{l}\text { Ending } \\
\text { Byte }\end{array}$ & Comment \\
\hline D.I & 1 & $\begin{array}{l}\text { Type of element } \\
\text { code }\end{array}$ & ALPHA & A2 & 1 & 2 & $\begin{array}{r}\text { Code }=' \mathrm{Nb} \text { ' for Node element, } \\
\text { ' } \mathrm{Ab} \text { ' for Area element. }\end{array}$ \\
\hline D.1 & 2 & $\begin{array}{l}\text { Element's internal } \\
\text { identification number }\end{array}$ & INTEGER $\star 2$ & I6 & 3 & 8 & $\begin{array}{l}\text { Unique within each category } \\
\text { and element type. }\end{array}$ \\
\hline D. 1 & 3 & $\begin{array}{l}x, y \text { file coordinate } \\
\text { of node point or repre- } \\
\text { sentative point for the } \\
\text { area element }\end{array}$ & INTEGER $\star 2$ & 216 & 9 & 20 & $\begin{array}{l}\text { The representative area } \\
\text { point is usually, but not } \\
\text { always, contained within the } \\
\text { area it represents. }\end{array}$ \\
\hline D. 1 & 4 & $\begin{array}{l}\text { Number }(t) \text { of attri- } \\
\text { bute codes which are } \\
\text { attached to the node } \\
\text { or area element }(t \geq 0)\end{array}$ & INTEGER *2 & I6 & 21 & 26 & $\begin{array}{l}\text { Absence of attribute codes } \\
\text { is indicated by } t=0 \text {. }\end{array}$ \\
\hline D.I & 5 & $\begin{array}{l}\text { Number }(k) \text { of pairs of } \\
\text { text characters which are } \\
\text { attached to the node or } \\
\text { area element }(k \geq 0)\end{array}$ & INTEGER *2 & I6 & 27 & 32 & $\mathrm{k}=0$. Not currently used. \\
\hline--- & --- & Filler & --- & --- & 33 & 144 & 112 spaces \\
\hline D. 2 & 1 & $\begin{array}{l}\text { Code indicating a } \\
\text { line segment graph } \\
\text { element }\end{array}$ & ALPHA & A2 & 1 & 2 & Code $={ }^{\prime} \mathrm{Lb}^{\prime}$ for line segment \\
\hline D. 2 & 2 & $\begin{array}{l}\text { Line segment's internal } \\
\text { identification number }\end{array}$ & INTEGER *2 & I6 & 3 & 8 & $\begin{array}{l}\text { This number is unique within } \\
\text { each category and element } \\
\text { type. }\end{array}$ \\
\hline $\mathrm{D} .2$ & 3 & $\begin{array}{l}\text { Internal identification } \\
\text { number of starting node }\end{array}$ & INTEGER $* 2$ & I6 & 9 & 14 & $\begin{array}{l}\text { Number refers to data } \\
\text { element } 2 \text { in record D.l. }\end{array}$ \\
\hline
\end{tabular}


APPENDIX A.--Standard DLG Distribution Format (Record Contents)--continued

\begin{tabular}{|c|c|c|c|c|c|c|c|}
\hline Record & Data & & Type & & Starting & Ending & \\
\hline Number & Element & Contents & ran Notation) & Format & Byte & Byte & Comment \\
\hline D. 2 & 4 & $\begin{array}{l}\text { Internal identification } \\
\text { number of ending node }\end{array}$ & INTEGER*2 & I6 & 15 & 20 & $\begin{array}{l}\text { Number refers to data } \\
\text { element } 2 \text { in record D. } 1 .\end{array}$ \\
\hline D. 2 & 5 & $\begin{array}{l}\text { Internal identification } \\
\text { number of left area }\end{array}$ & INTEGER *2 & I6 & 21 & 26 & $\begin{array}{l}\text { Number refers to data } \\
\text { element } 2 \text { in record D.I. }\end{array}$ \\
\hline D. 2 & 6 & $\begin{array}{l}\text { Internal identification } \\
\text { number of right area }\end{array}$ & INTEGER *2 & I6 & 27 & 32 & $\begin{array}{l}\text { Number refers to data } \\
\text { element } 2 \text { in record D. } 1 \text {. }\end{array}$ \\
\hline D. 2 & 7 & $\begin{array}{l}\text { Number }(v) \text { of coordinate } \\
\text { pairs which define the } \\
\text { line segment }\end{array}$ & INTEGER *2 & I6 & 33 & 38 & $\begin{array}{l}\text { The value of } v \text { is between } \\
2 \text { and } 1500 \text {. }\end{array}$ \\
\hline D. 2 & 8 & $\begin{array}{l}\text { Number }(t) \text { of attri- } \\
\text { bute codes which are } \\
\text { attached to the line } \\
\text { segment }(t \geq 0)\end{array}$ & INTEGER *2 & I6 & 39 & 44 & $\begin{array}{l}\text { Absence of classification } \\
\text { attribute codes is indicated } \\
\text { by } t=0 \text {. }\end{array}$ \\
\hline \multirow[t]{2}{*}{ D. 2} & 9 & $\begin{array}{l}\text { Number }(k) \text { of pairs of } \\
\text { text characters which } \\
\text { are attached to the } \\
\text { line segment }(k \geq 0)\end{array}$ & INTEGER *2 & I6 & 45 & 50 & $k=0$. Not currently used. \\
\hline & -- & Filler & --- & --- & 51 & 144 & 94 spaces \\
\hline
\end{tabular}


APPENDIX A.--Standard DLG Distribution Format (Record Contents)--continued

\begin{tabular}{|c|c|c|c|c|c|c|c|}
\hline $\begin{array}{l}\text { Record } \\
\text { Number }\end{array}$ & $\begin{array}{l}\text { Data } \\
\text { Element }\end{array}$ & (Fortr & $\begin{array}{l}\text { Type } \\
\text { ran Notation) }\end{array}$ & Format & $\begin{array}{l}\text { Starting } \\
\text { Byte }\end{array}$ & $\begin{array}{l}\text { Ending } \\
\text { Byte }\end{array}$ & Comment \\
\hline $\begin{array}{l}\text { E.1 to } \\
\text { E.n }\end{array}$ & 1 & $\begin{array}{l}\text { A }(v, 2) \text { array contain- } \\
\text { ing an ordered sequence } \\
\text { of coordinate pairs which } \\
\text { define the image presen- } \\
\text { tation of a line element }\end{array}$ & INTEGER*2 & $v(2 I 6)$ & 1 & & $\begin{array}{l}\text { Coordinates are expressed } \\
\text { in internal file reference } \\
\text { system, in units of } \\
\text { thousandths of an inch. } \\
\text { The array is stored by row. }\end{array}$ \\
\hline--- & --- & Filler & --- & -- & --- & --- & 0 to 132 spaces \\
\hline
\end{tabular}

${ }^{2}$ The number of coordinate pairs, "v", is given in record D.2. There will be v(2I6) coordinate pairs of which a maximum of 12 pairs will fit on a 144 character ASCII record. The space filler will vary in size depending on the value of "v." If "v" equals 12 or is an integer multiple of 12, there will be no spaces as filler at the end of the record. 
APPENDIX A.--Standard DLG Distribution Format (Record Contents)--continued

Logical Record Type F

\begin{tabular}{|c|c|c|c|c|c|c|c|}
\hline $\begin{array}{l}\text { Record } \\
\text { Number } \\
\end{array}$ & $\begin{array}{l}\text { Data } \\
\text { Element }\end{array}$ & Contents & $\begin{array}{c}\text { Type } \\
\text { Fortran Notation) }\end{array}$ & Format & $\begin{array}{l}\text { Starting } \\
\text { Byte }\end{array}$ & $\begin{array}{l}\text { Ending } \\
\text { Byte }\end{array}$ & Comment \\
\hline $\begin{array}{l}\mathrm{F} \cdot \mathrm{I}^{3} \\
\text { to } \mathrm{F} \cdot \mathrm{n}\end{array}$ & 1 & $\begin{array}{l}\text { A }(t, 2) \text { array containing } \\
\text { major and minor attribute } \\
\text { codes for a graph element }\end{array}$ & $\begin{array}{l}\text { gNTEGER* } 2 \\
\text { te } \\
\text { nt }\end{array}$ & $t(2 I 6)$ & 1 & & $\begin{array}{l}\text { The array is stored by row } \\
\text { with the first column con- } \\
\text { taining the major attribute } \\
\text { code and the second column } \\
\text { containing the minor attri- } \\
\text { bute code. }\end{array}$ \\
\hline--- & --- & Filler & --- & --- & --- & --- & 0 to 132 spaces \\
\hline
\end{tabular}

${ }^{3}$ The number of feature (attribute) codes, " $t$ " is given in the D.I and D.2 records. The $F$ record is an array of $t$ (2I6) codes of which a maximum of $12(216)$ will fit on a 144 character ASCII record. The space filler will vary depending on the value of "t". If " $t$ " is 12 or an integer multiple of 12 there will be no spaces as filler at the end of the record. 


\section{APPENDIX B.--Optional DLG Distribution Format (Record Contents)}

In the optional DLG distribution format, topological linkages are explicitly encoded for node and area elements as well as for line elements. The files are physically comprised of 8-bit ASCII characters organized into fixed-length logical records of 80 characters (bytes). Bytes 1-72 of each record may contain DLG data, and bytes 73-80 may contain a record sequence number.

The 11 distinct record types used in the optional DLG distribution format may be categorized as header and data records.

Four types of records are considered header records:

- File identification and description records

- $\quad$ Accuracy records (not currently used)

- $\quad$ Control-point identification records

- Data-category identification records

Seven types of records are considered data records:

- $\quad$ Node and area identification records

- $\quad$ Node-to-line linkage records

- $\quad$ Area-to-line linkage records

- Line identification records (also contains line-to-node and line-to-area linkages)

- $\quad$ Coordinate string records

- $\quad$ Attribute code records

- Text records (not currently used)

The actual sequence of records in an optional distribution format DLG file is as follows:

1. Header records

Ten file identification and description records

Accuracy records (not currently used)

Control point identification records (one per control-point)

Data category identification records (one per data category in the file)

2. Data records

Node identification record Node-to-line linkage record(s) Attribute code record(s) Text record(s)

Area identification record Area-to-line linkage record(s) Attribute code record(s) Text record(s)

Repeated for each node within a data category

Line identification records Coordinate string record(s) Attribute code record(s) Text record(s)

$\left\{\begin{array}{l}\text { Repeated } \\ \text { for each } \\ \text { area within a } \\ \text { data category }\end{array}\right.$

Repeated for each data category

Descriptions of the contents of the various types of records in an optional distribution format DLG are contained in the following tables. 
APPENDIX B.--Optional DLG Distribution Format (Record Contents)--continued

\begin{tabular}{|c|c|c|c|c|c|c|c|}
\hline $\begin{array}{l}\text { Record } \\
\text { Number } \\
\end{array}$ & $\begin{array}{l}\text { Data } \\
\text { Element }\end{array}$ & Contents & $\begin{array}{c}\text { Type } \\
\text { (Fortran Notation) }\end{array}$ & Format & $\begin{array}{l}\text { Starting } \\
\text { Byte }\end{array}$ & $\begin{array}{l}\text { Ending } \\
\text { Byte }\end{array}$ & Comment \\
\hline 1 & 1 & Banner & ALPHA & A72 & 1 & 72 & Descriptive text \\
\hline 2 & 1 & $\begin{array}{l}\text { Name of digital } \\
\text { cartographic unit }\end{array}$ & ALPHA & A40 & 1 & 40 & The name of the map \\
\hline--- & --- & Filler & --- & --- & 41 & 41 & 1 space \\
\hline 2 & 2 & $\begin{array}{l}\text { Date of original } \\
\text { source material }\end{array}$ & ALPHA & Alo & 42 & 51 & $\begin{array}{l}\text { Year of original source } \\
\text { material followed by latest } \\
\text { revision date if applicable, } \\
\text { for example, } 1956,1965 \text {. }\end{array}$ \\
\hline-- & & Filler & -- & --- & 52 & 52 & 1 space \\
\hline 2 & 3 & $\begin{array}{l}\text { Scale of original } \\
\text { source material }\end{array}$ & INTEGER * 4 & I8 & 53 & 60 & $\begin{array}{l}\text { Scale denominator of source } \\
\text { material, for example, } \\
2000000 \text {. }\end{array}$ \\
\hline--- & & Filler & -- & & 61 & 72 & 12 spaces \\
\hline 3 & & Filler & --- & --- & 1 & 80 & 80 spaces \\
\hline
\end{tabular}


APPENDIX B.--Optional DLG Distribution Format (Record Contents)--continued

\begin{tabular}{|c|c|c|c|c|c|c|c|}
\hline $\begin{array}{l}\text { Record } \\
\text { Number } \\
\end{array}$ & $\begin{array}{l}\text { Data } \\
\text { Element }\end{array}$ & Contents & $\begin{array}{l}\text { Type } \\
\text { rtran Notation) } \\
\end{array}$ & Format & $\begin{array}{l}\text { Starting } \\
\text { Byte }\end{array}$ & $\begin{array}{l}\text { Ending } \\
\text { Byte }\end{array}$ & Comment \\
\hline 4 & 1 & DLG level code & INTEGER*2 & I6 & 1 & 6 & Code $=3$, DLG -3 \\
\hline 4 & 2 & $\begin{array}{l}\text { Code defining ground } \\
\text { planimetric reference } \\
\text { system }\end{array}$ & INTEGER $* 2$ & I6 & 7 & 12 & $\begin{array}{l}\text { Code }=3, \text { Albers Equal-Area } \\
\text { Conic }\end{array}$ \\
\hline 4 & 3 & $\begin{array}{l}\text { Code defining zone in } \\
\text { ground planimetric } \\
\text { reference system }\end{array}$ & INTEGER $* 2$ & I6 & 13 & 18 & Code $=9999$ \\
\hline 4 & 4 & $\begin{array}{l}\text { Code defining units } \\
\text { of measure for ground } \\
\text { planimetric coordinates } \\
\text { throughout the file }\end{array}$ & INTEGER $\star 2$ & I6 & 19 & 24 & Code $=2$, meters \\
\hline 4 & 5 & Resolution & $\mathrm{REAL} \star 4$ & D18.11 & 25 & 42 & $\begin{array}{l}\text { The true ground distance } \\
\text { corresponding to one unit } \\
(0.001 \text { inch at map scale) } \\
\text { in the file internal coor- } \\
\text { dinate system used in data } \\
\text { collection. For } 1: 2,000,000- \\
\text { scale } 0.001 \text { inch equals } 50.8 \\
\text { meters. }\end{array}$ \\
\hline 4 & 6 & $\begin{array}{l}\text { Number of file-to- } \\
\text { map transformation } \\
\text { parameters }\end{array}$ & INTEGER * 2 & I6 & 43 & 48 & Usually 4 \\
\hline 4 & 7 & $\begin{array}{l}\text { Number of accuracy/ } \\
\text { miscellaneous records }\end{array}$ & INTEGER $\star 2$ & I6 & 49 & 54 & Currently $=0$, none included \\
\hline
\end{tabular}


APPENDIX B.--Optional DLG Distribution Format (Record Contents)--continued

\begin{tabular}{|c|c|c|c|c|c|c|c|}
\hline $\begin{array}{l}\text { Record } \\
\text { Number } \\
\end{array}$ & $\begin{array}{l}\text { Data } \\
\text { Element }\end{array}$ & (Fort & $\begin{array}{l}\text { Type } \\
\text { ran Notation) }\end{array}$ & Format & $\begin{array}{l}\text { Starting } \\
\text { Byte }\end{array}$ & $\begin{array}{l}\text { Ending } \\
\text { Byte }\end{array}$ & Comment \\
\hline 4 & 8 & $\begin{array}{l}\text { Number }(n) \text { of } \\
\text { control-points }\end{array}$ & INTEGER $* 2$ & I6 & 55 & 60 & Usually 4 \\
\hline 4 & 9 & $\begin{array}{l}\text { Number }(q) \text { of categories } \\
\text { in the DLG file }\end{array}$ & INTEGER *2 & I6 & 61 & 66 & $\begin{array}{l}1 \leq q \leq 32 \text {. Up to } 32 \text { cate- } \\
\text { gories can be represented } \\
\text { in a given file; however, } \\
\text { all } 1: 2,000,000-\text { scale data } \\
\text { files include only one. }\end{array}$ \\
\hline--- & -- & Filler & --- & --- & 67 & 72 & 6 spaces \\
\hline $5-9$ & 1 & $\begin{array}{l}\text { Projection parameters } \\
\text { for map transformation }\end{array}$ & REAL $\star 8$ & $3 \mathrm{D} 24.15$ & 1 & 72 & $\begin{array}{l}\text { Three parameters on each of } \\
5 \text { records. Parameters for } \\
\text { the Albers Equal-Area Conic } \\
\text { projection are given in } \\
\text { Appendix D. }\end{array}$ \\
\hline 10 & 1 & $\begin{array}{l}\text { Internal file-to- } \\
\text { map projection } \\
\text { transformation } \\
\text { parameters }\end{array}$ & REAL * 4 & $4 \mathrm{Dl} 18.11$ & 1 & 72 & $\begin{array}{l}\text { A transformation of this } \\
\text { type is not required, since } \\
\text { coordinates are expressed } \\
\text { in a ground planimetric } \\
\text { coordinate system (Albers } \\
\text { Equal-Area Conic). These } \\
\text { parameters are, however, } \\
\text { valid for transformation } \\
\text { as described in record B.1, } \\
\text { data element } 1 \text {, of the } \\
\text { standard format. }\end{array}$ \\
\hline
\end{tabular}


APPENDIX B.--Optional DLG Distribution Format (Record Contents)--continued

\begin{tabular}{|c|c|c|c|c|c|c|c|}
\hline \multirow[b]{2}{*}{$\begin{array}{l}\text { Record } \\
\text { Number } \\
\end{array}$} & \multicolumn{6}{|c|}{ CONTROL-POINT IDENTIFICATION RECORDS } & \multirow[b]{2}{*}{ Comment } \\
\hline & $\begin{array}{l}\text { Data } \\
\text { Element }\end{array}$ & Contents & $\begin{array}{c}\text { Type } \\
\text { (Fortran Notation) }\end{array}$ & Format & $\begin{array}{l}\text { Starting } \\
\text { Byte }\end{array}$ & $\begin{array}{l}\text { Ending } \\
\text { Byte }\end{array}$ & \\
\hline \multirow[t]{7}{*}{$1-n$} & 1 & Control-point label & ALPHA & A2 & 1 & 2 & $\begin{array}{l}\text { "SW," "NW, " "NE, " or "SE" } \\
\text { for four quadrangle } \\
\text { corners. }\end{array}$ \\
\hline & & Filler & & & 3 & 6 & 4 spaces \\
\hline & 2 & Latitude & $\mathrm{REAL} \star 4$ & F12.6 & 7 & 18 & $\begin{array}{l}\text { In degrees and decimal } \\
\text { degrees. }\end{array}$ \\
\hline & 3 & Longitude & REAL *4 & $\mathrm{F} 12.6$ & 19 & 30 & $\begin{array}{l}\text { In degrees and decimal } \\
\text { degrees. }\end{array}$ \\
\hline & & Filler & & & 31 & 36 & 6 spaces \\
\hline & 4 & Internal file $x$ & REAL * 4 & F12.2 & 37 & 48 & $\begin{array}{l}\text { In units in the appropriate } \\
\text { zone of the ground plani- } \\
\text { metric coordinate system. }\end{array}$ \\
\hline & 5 & Internal file $y$ & $\mathrm{REAL} * 4$ & F 12.2 & 49 & 60 & $\begin{array}{l}\text { In units in the appropriate } \\
\text { zone of the ground plani- } \\
\text { metric coordinate system. }\end{array}$ \\
\hline--- & -- & Filler & -- & -- & 61 & 72 & 12 spaces \\
\hline
\end{tabular}


APPENDIX B.--Optional DLG Distribution Format (Record Contents)--continued

\begin{tabular}{|c|c|c|c|c|c|c|c|}
\hline $\begin{array}{l}\text { Record } \\
\text { Number } \\
\end{array}$ & $\begin{array}{l}\text { Data } \\
\text { Element }\end{array}$ & Contents & $\begin{array}{c}\text { Type } \\
\text { Fortran Notation) }\end{array}$ & Format & $\begin{array}{l}\text { Starting } \\
\text { Byte }\end{array}$ & $\begin{array}{l}\text { Ending } \\
\text { Byte }\end{array}$ & Comment \\
\hline \multirow[t]{9}{*}{$1-q$} & 1 & Category name & ALPHA & A20 & 1 & 20 & $\begin{array}{l}\text { The first } 4 \text { characters are } \\
\text { unique. }\end{array}$ \\
\hline & 2 & Attribute format codes & INTEGER *2 & I4 & 21 & 24 & $\begin{array}{l}\text { Blank or zero }(0) \text { indicates } \\
\text { default }(2 I 6) \text { attribute } \\
\text { formatting in major-minor } \\
\text { pairs. }\end{array}$ \\
\hline & 3 & $\begin{array}{l}\text { Number of nodes refer- } \\
\text { enced in file }\end{array}$ & INTEGER *2 & I6 & 25 & 30 & $\begin{array}{l}\text { Number of nodes referenced } \\
\text { in file as start and end } \\
\text { nodes of lines. }\end{array}$ \\
\hline & 4 & $\begin{array}{l}\text { Actual number of } \\
\text { nodes in file }\end{array}$ & INTEGER *2 & I6 & 31 & 36 & $\begin{array}{l}\text { Only if some or all node } \\
\text { records were excluded from } \\
\text { the file, would this number } \\
\text { be different from data } \\
\text { element } 3 \text {. }\end{array}$ \\
\hline & & Filler & --- & -- & 37 & 37 & 1 space \\
\hline & 5 & $\begin{array}{l}\text { Presence of node-to- } \\
\text { area linkage records }\end{array}$ & INTEGER *2 & Il & 38 & 38 & $\begin{array}{l}\text { Flag }=0, \text { node-to-area } \\
\text { linkage records not } \\
\text { present. }\end{array}$ \\
\hline & 6 & $\begin{array}{l}\text { Presence of node-to- } \\
\text { line linkage records }\end{array}$ & INTEGER *2 & Il & 39 & 39 & $\begin{array}{l}\text { Flag=l, node-to-line } \\
\text { linkage records are } \\
\text { included. }\end{array}$ \\
\hline & -- & Filler & -- & --- & 40 & 40 & I zero or space \\
\hline & 7 & $\begin{array}{l}\text { Number of areas refer- } \\
\text { enced in file }\end{array}$ & INTEGER $* 2$ & I6 & 41 & 46 & $\begin{array}{l}\text { Number of areas referenced } \\
\text { in file as areas left and } \\
\text { areas right of lines. }\end{array}$ \\
\hline
\end{tabular}

${ }^{1}$ The flags for lists present or absent are the current default values, and are the only current values used. 
APPENDIX B.--Optional DLG Distribution Format (Record Contents)--continued

\begin{tabular}{|c|c|c|c|c|c|c|c|}
\hline $\begin{array}{l}\text { Record } \\
\text { Number }\end{array}$ & $\begin{array}{l}\text { Data } \\
\text { Element }\end{array}$ & Contents & $\begin{array}{c}\text { Type } \\
\text { Fortran Notation) }\end{array}$ & Format & $\begin{array}{l}\text { Starting } \\
\text { Byte }\end{array}$ & $\begin{array}{l}\text { Ending } \\
\text { Byte }\end{array}$ & Comment \\
\hline \multirow[t]{9}{*}{$1-q$} & 8 & $\begin{array}{l}\text { Actual number of areas } \\
\text { in file }\end{array}$ & INTEGER*2 & I6 & 47 & 52 & $\begin{array}{l}\text { Only if some or all area } \\
\text { records were excluded from } \\
\text { the file would the number } \\
\text { be different from the data } \\
\text { element } 7 \text {. }\end{array}$ \\
\hline & --- & Filler & --- & --- & 53 & 53 & 1 space \\
\hline & 9 & $\begin{array}{l}\text { Presence of area-to- } \\
\text { node linkage records }\end{array}$ & INTEGER *2 & II & 54 & 54 & $\begin{array}{l}\text { Flag=0, area-to-node } \\
\text { linkage records not } \\
\text { present. }{ }^{1}\end{array}$ \\
\hline & 10 & $\begin{array}{l}\text { Presence of area-to- } \\
\text { line linkage records }\end{array}$ & INTEGER *2 & Il & 55 & 55 & $\begin{array}{l}\text { Flag=l, area-to-line } \\
\text { linkage records are } \\
\text { included. }{ }^{1}\end{array}$ \\
\hline & 11 & $\begin{array}{l}\text { Presence of area- } \\
\text { coordinate lists }\end{array}$ & INTEGER *2 & Il & 56 & 56 & $\begin{array}{l}\text { Flag }=0 \text {, area-coordinate } \\
\text { lists not present. }{ }^{1}\end{array}$ \\
\hline & 12 & $\begin{array}{l}\text { Number of lines } \\
\text { referenced in file }\end{array}$ & INTEGER *2 & I6 & 57 & 62 & $\begin{array}{l}\text { Number of lines referenced } \\
\text { in area-to-line and node- } \\
\text { to-line records. }\end{array}$ \\
\hline & 13 & $\begin{array}{l}\text { Actual number of } \\
\text { lines in file }\end{array}$ & INTEGER *2 & I6 & 63 & 68 & $\begin{array}{l}\text { Only if some lines were } \\
\text { excluded from the file } \\
\text { would this number be } \\
\text { different from data element } \\
12 \text {. }\end{array}$ \\
\hline & --- & Filler & -- & --- & 69 & 71 & 3 spaces \\
\hline & 14 & $\begin{array}{l}\text { Presence of line- } \\
\text { coordinate lists }\end{array}$ & INTEGER *2 & Il & 72 & 72 & $\begin{array}{l}\text { Flag }=1 \text {, line-coordinate } \\
\text { lists are included. }\end{array}$ \\
\hline
\end{tabular}

${ }^{1}$ The flags for lists present or absent are the current default values, and are the only current values used. 
APPENDIX B.--Optional DLG Distribution Format (Record Contents)--continued

\begin{tabular}{|c|c|c|c|c|c|c|c|}
\hline \multirow[t]{10}{*}{ Number } & $\begin{array}{l}\text { Data } \\
\text { Element }\end{array}$ & Contents & $\begin{array}{l}\text { Type } \\
\text { ran Notation) }\end{array}$ & Format & $\begin{array}{l}\text { Starting } \\
\text { Byte }\end{array}$ & $\begin{array}{l}\text { Ending } \\
\text { Byte }\end{array}$ & Comment \\
\hline & 1 & Record type & ALPHA & Al & 1 & 1 & "N" or "A" \\
\hline & 2 & $\begin{array}{l}\text { Element internal } \\
\text { ID number }\end{array}$ & INTEGER *2 & I5 & 2 & 6 & $\begin{array}{l}\text { This value is unique within } \\
\text { each category and element } \\
\text { type. }\end{array}$ \\
\hline & 3 & $\begin{array}{l}\text { Coordinates of node } \\
\text { point or representative } \\
\text { point for area }\end{array}$ & $\mathrm{REAL} \star 4$ & $2 \mathrm{~F} 12.2$ & 7 & 30 & $\begin{array}{l}\text { The area point is usually, } \\
\text { but not always within the } \\
\text { polygon it represents. }\end{array}$ \\
\hline & 4 & $\begin{array}{l}\text { Number of elements in } \\
\text { an area list (for nodes), } \\
\text { or in a node list } \\
\text { (for areas) }\end{array}$ & INTEGER *2 & I 6 & 31 & 36 & $\begin{array}{l}\text { Blank or zero }(0) \text {. These } \\
\text { lists are not currently } \\
\text { included. }\end{array}$ \\
\hline & 5 & $\begin{array}{l}\text { Number of elements in } \\
\text { line segment list }\end{array}$ & INTEGER *2 & I 6 & 37 & 42 & $\begin{array}{l}\text { Number of line segments } \\
\text { that intersect at the node, } \\
\text { or bound the area. }\end{array}$ \\
\hline & 6 & $\begin{array}{l}\text { Number of } x, y \text { or } \\
\text { lat-long points } \\
\text { in area-coordinate } \\
\text { list }\end{array}$ & INTEGER *2 & I6 & 43 & 48 & $\begin{array}{l}\text { Blank or zero }(0) \text {. These } \\
\text { lists are not currently } \\
\text { included. }\end{array}$ \\
\hline & 7 & $\begin{array}{l}\text { Number of attribute } \\
\text { codes listed }\end{array}$ & INTEGER * 2 & I 6 & 49 & 54 & $\begin{array}{l}\text { Number of attribute codes } \\
\text { listed. }\end{array}$ \\
\hline & 8 & $\begin{array}{l}\text { Number of text } \\
\text { characters listed }\end{array}$ & INTEGER*2 & I6 & 55 & 60 & $\begin{array}{l}\text { Zero }(0) \text {. There are no } \\
\text { text attributes for } \\
1: 2,000,000-\text { scale DLG data. }\end{array}$ \\
\hline & 9 & $\begin{array}{l}\text { Number of islands } \\
\text { within area }\end{array}$ & INTEGER *2 & I 6 & 61 & 66 & $\begin{array}{l}\text { Area records only, } 6 \text { spaces } \\
\text { for node records. }\end{array}$ \\
\hline--- & -- & Filler & --- & --- & 67 & 72 & 6 spaces \\
\hline
\end{tabular}


APPENDIX B.--Optional DLG Distribution Format (Record Contents)--continued

NODE-TO-LINE LINKAGE RECORDS

FORTRAN FORMAT (12I6), for each node: The list consists of line segment internal ID numbers (which appear in bytes 2- 6 of the line identification records). The line segments which begin at this node are included in the list as positive ID numbers. The line segments which terminate at this node are included as negative ID numbers. There is no logical order to the list.

\section{AREA-TO-LINE LINKAGE RECORDS}

FORTRAN format (1216), for each area: The list consists of line segment internal ID numbers (which appear in bytes 2-6 of the line identification records) and, for those areas with islands (indicated by bytes $61-66$ of the area's first record), zero (0) elements marking the beginning of islands. Line segments with this area to the right are included as positive ID numbers.

Line segments with this area to the left are included as negative ID numbers. The list is ordered clockwise around the perimeter of the area and counterclockwise around each island, if any (counterclockwise around an island of an area is still a clockwise direction in reference to the area itself). A zero (0) element is inserted in the list before each island sublist. 
APPENDIX B.--Optional DLG Distribution Format (Record Contents)--continued

\begin{tabular}{|c|c|c|c|c|c|c|c|}
\hline \multirow[t]{11}{*}{ Number } & $\begin{array}{l}\text { Data } \\
\text { Element }\end{array}$ & Contents & $\begin{array}{l}\text { Type } \\
\text { ran Notation) }\end{array}$ & Format & $\begin{array}{l}\text { Starting } \\
\text { Byte }\end{array}$ & $\begin{array}{l}\text { Ending } \\
\text { Byte }\end{array}$ & Comment \\
\hline & 1 & Record type & & Al & 1 & 1 & "L" \\
\hline & 2 & Element internal ID numbe & & I5 & 2 & 6 & $\begin{array}{l}\text { This number is unique within } \\
\text { each category and element } \\
\text { type. }\end{array}$ \\
\hline & 3 & Starting node & & I6 & 7 & 12 & $\begin{array}{l}\text { Internal ID number. This } \\
\text { refers to data element } 2 \text { of } \\
\text { the node identification } \\
\text { record. }\end{array}$ \\
\hline & 4 & Ending node & & I6 & 13 & 18 & $\begin{array}{l}\text { Internal ID number. This } \\
\text { refers to data element } 2 \text { of } \\
\text { the node identification } \\
\text { record. }\end{array}$ \\
\hline & 5 & Left area & & I6 & 19 & 24 & $\begin{array}{l}\text { Internal ID number. This } \\
\text { refers to data element } 2 \text { of } \\
\text { the area identification } \\
\text { record. }\end{array}$ \\
\hline & 6 & Right area & & I6 & 25 & 30 & $\begin{array}{l}\text { Internal ID number. This } \\
\text { refers to data element } 2 \text { of } \\
\text { the area identification } \\
\text { record. }\end{array}$ \\
\hline & --- & Filler & & --- & 31 & 42 & 12 spaces \\
\hline & 7 & $\begin{array}{l}\text { Number of } x, y \text { coordinates } \\
\text { listed }\end{array}$ & & I6 & 43 & 48 & $\begin{array}{l}\text { Number of coordinate } \\
\text { pairs listed. }\end{array}$ \\
\hline & 8 & $\begin{array}{l}\text { Number of attribute codes } \\
\text { listed }\end{array}$ & & I6 & 49 & 54 & $\begin{array}{l}\text { Number of attributes (or two } \\
\text { element attribute pairs) } \\
\text { listed. }\end{array}$ \\
\hline & 9 & Number of text characters & listed & I6 & 55 & 60 & $\begin{array}{l}\text { Zero }(0) \text {. There are no text } \\
\text { data associated with } \\
1: 2,000,000-\text { scale DLG } \\
\text { data. }\end{array}$ \\
\hline
\end{tabular}


COORDINATE STRING RECORDS

FORTRAN format (3(2F12.2)): The coordinates are in appropriate units in the designated ground planimetric coordinate system (Albers Equal-Area Conic projection). The file-to-map projection parameters in Header record 10 are set to ( $1.0,0.0,0.0,0.0)$ for real map projection coordinates (the transformation formulas still apply).

CODE RECORDS

As major-minor attribute code pairs, FORTRAN format (6(2I6)): within each pair, the first integer is the major code and the second integer is the minor code. Each major and minor code is a one-to-four-digit integer, right justified within the six-byte field. 


\section{APPENDIX C.--Graphic Format}

The simplified, graphic format that can be used with the GS-CAM plotting package is described below. In this format, each line record from the DLG format has been reformatted into two record types: one line identifier record and multiple latitude-longitude records (one for each coordinate pair). Supplementary coordinate pairs have been added to Graphic Format data in instances where the distance between two adjacent vertices was greater than 0.01 " in the original DLG line description. These additional points assure that the distance between any two data points of a line are no greater than 0.01 " and minimizes distortion of the line when projection transformations are applied. If a line record has more than one attribute code associated with it in the DLG format, that line record appears in the graphic format files multiple times (once for each attribute code). The graphic format files are organized by feature type.

Record 1: Line identifier record

Position Length Format

1. Line identifier

2. Rank (last two digits of attribute code

1-7

8-9

(described in Appendix E--unique within category)

3. Number of points in the line (NP)

(latitude and longitude)

4. First five digits of attribute code

(described in Appendix E)

Record 2: Latitude-longitude record (repeated NP times)

1. Latitude (DDMMSSI)

1-7

2. Longitude (DDDMMSSI)

8-15

3. Sequence count

$\begin{array}{ll}7 & \text { I }\end{array}$

16


The standard and optional DLG distribution formats include 15 fields reserved for map projection parameters. These parameters are typically used as input for a coordinate transformation package such as the USGS General Coordinate Transformation Package (GCTP).

When the ground coordinate system of a DLG is the Albers Equal-Area Conic projection, as in the case for all DLG's digitized from 1:2,000,000-scale maps, the first eight parameter fields are used:

1. Semimajor axis of ellipsoid

2. Eccentricity squared of ellipsoid

3 Latitude of first standard parallel

4. Latitude of second standard parallel

5. Longitude of central meridian

6. Latitude of projection origin

7. False easting

8. False northing

9-15. Not used

For the 1:2,000,000-scale files, the following parameters were used:

For all maps:

Spheroid parameters: Clarke 1866

False easting: 0.0

False northing: 0.0

For conterminous United States:

First standard parallel: $29.5^{\circ}$ North

Second standard parallel: $45.5^{\circ}$ North

Longitude of central meridian: $96^{\circ}$ West

Latitude of projection origin: $23^{\circ}$ North

For Hawaii:

First standard parallel: $8^{\circ}$ North

Second standard parallel: $18^{\circ}$ North

Longitude of central meridian: $157^{\circ}$ West

Latitude of projection origin: $3^{\circ}$ North

For Alaska:

First standard parallel: $55^{\circ}$ North

Second standard parallel: $65^{\circ}$ North

Longitude of central meridian: $154^{\circ}$ West

Latitude of projection origin: $50^{\circ}$ North

A transformation to or from Albers Equal-Area Conic projection coordinates using GCTP can be controlled by specifying the parameters stated above. In the projection parameters of a DLG file, the longitude-latitude parameter values are encoded as packed, degrees-minutes-seconds (DMS) as follows:

$$
\text { degrees } * 1000000+\text { minutes } * 1000+\text { seconds }
$$

For example, if degrees $=+50$, minutes $=30$, and seconds $=36.25$, then the parameter value is 50030036.25 stored as a REAL*8 variable, and "bbb0.500300362500000D 08" encoded in FORTRAN D24.15 format. 
APPENDIX E.--DLG Attribute Codes

\begin{tabular}{|c|c|c|c|}
\hline FEATURE & $\begin{array}{l}\text { MAJOR } \\
\text { CODE }\end{array}$ & $\begin{array}{l}\text { MINOR } \\
\text { CODE }\end{array}$ & DESCRIPTION \\
\hline \multicolumn{4}{|r|}{ AREA ATTRIBUTES - Available in standard and optional DLG formats (only) } \\
\hline Water Bodies... & .040 & $\begin{array}{l}0100 \\
0102 \\
0104 \\
0105 \\
0106 \\
0107 \\
0110 \\
0150 \\
0199\end{array}$ & $\begin{array}{l}\text { Perennial lake or pond } \\
\text { Intermittent lake or pond } \\
\text { Dry lake or pond } \\
\text { Alkali flat } \\
\text { Reservoir } \\
\text { Intermittent reservoir } \\
\text { Glacier or snowfield } \\
\text { Island } \\
\text { Area not in water body (remainder of map) }\end{array}$ \\
\hline $\begin{array}{l}\text { Political } \\
\text { Boundaries }\end{array}$ & 090 & $\begin{array}{l}0100 \\
0101 \\
0197 \\
0198 \\
0199\end{array}$ & $\begin{array}{l}\text { Civil township, district, precint, or barrio } \\
\text { Incorporated city, village, town, borough, or hamlet } \\
\text { Canada } \\
\text { Mexico } \\
\text { Area outside a national boundary }\end{array}$ \\
\hline $\begin{array}{l}\text { Administrative } \\
\text { Boundaries }\end{array}$ & 090 & $\begin{array}{l}0103 \\
0104 \\
0105 \\
0106 \\
0107 \\
0108\end{array}$ & $\begin{array}{l}\text { National park, monument, lakeshore, parkway, battlefield, or recreation area } \\
\text { National forest or grassland } \\
\text { National wildlife refuge, game preserve, or fish hatchery } \\
\text { National scenic waterways or wilderness area } \\
\text { Indian reservation } \\
\text { Military reservation }\end{array}$ \\
\hline \multirow{2}{*}{\multicolumn{4}{|c|}{ PARAMETER CODES - Available in standard and optional DLG formats (only) }} \\
\hline & & & \\
\hline $\begin{array}{l}\text { Roads and } \\
\text { Trails }\end{array}$ & $\begin{array}{l}102 \\
103 \\
104\end{array}$ & $\begin{array}{l}0--- \\
0--- \\
0---\end{array}$ & $\begin{array}{l}\text { Interstate route number, two or three digits flush right } \\
\text { U.S. route number, two or three digits flush right } \\
\text { state route number, two or three digits flush right }\end{array}$ \\
\hline
\end{tabular}


APPENDIX E.--DLG Attribute Codes--continued

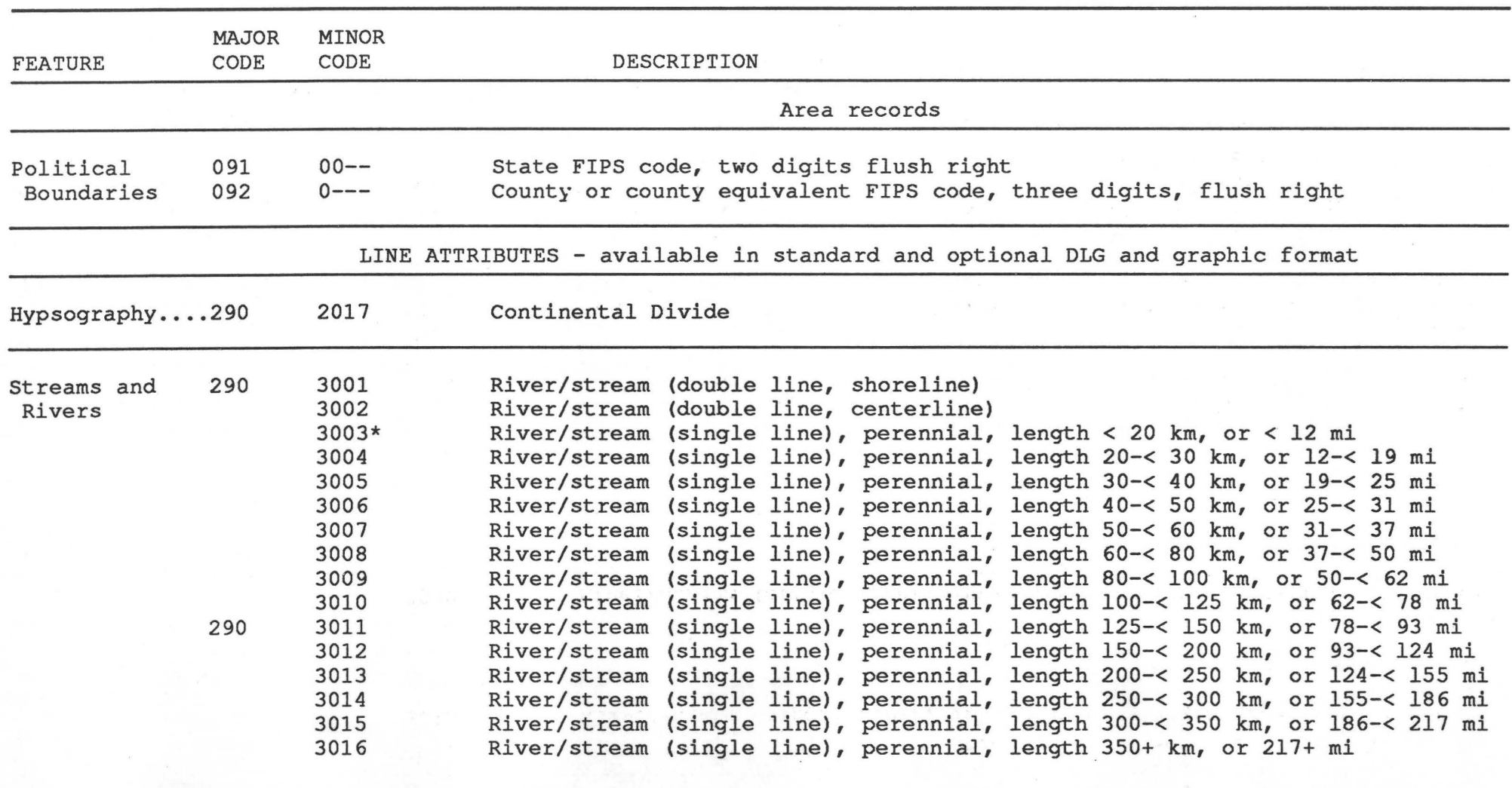

*This code was only used in the Alaskan drainage files.

Note:

Listing of FIPS codes available as National Bureau of Standards (U.S.), Federal Information Processing Standards Publication (FIPS PUB) 6-3, $39 \mathrm{p}$. for sale by the National Technical Information Service, U.S. Department of Commerce, Springfield, VA 22161. 


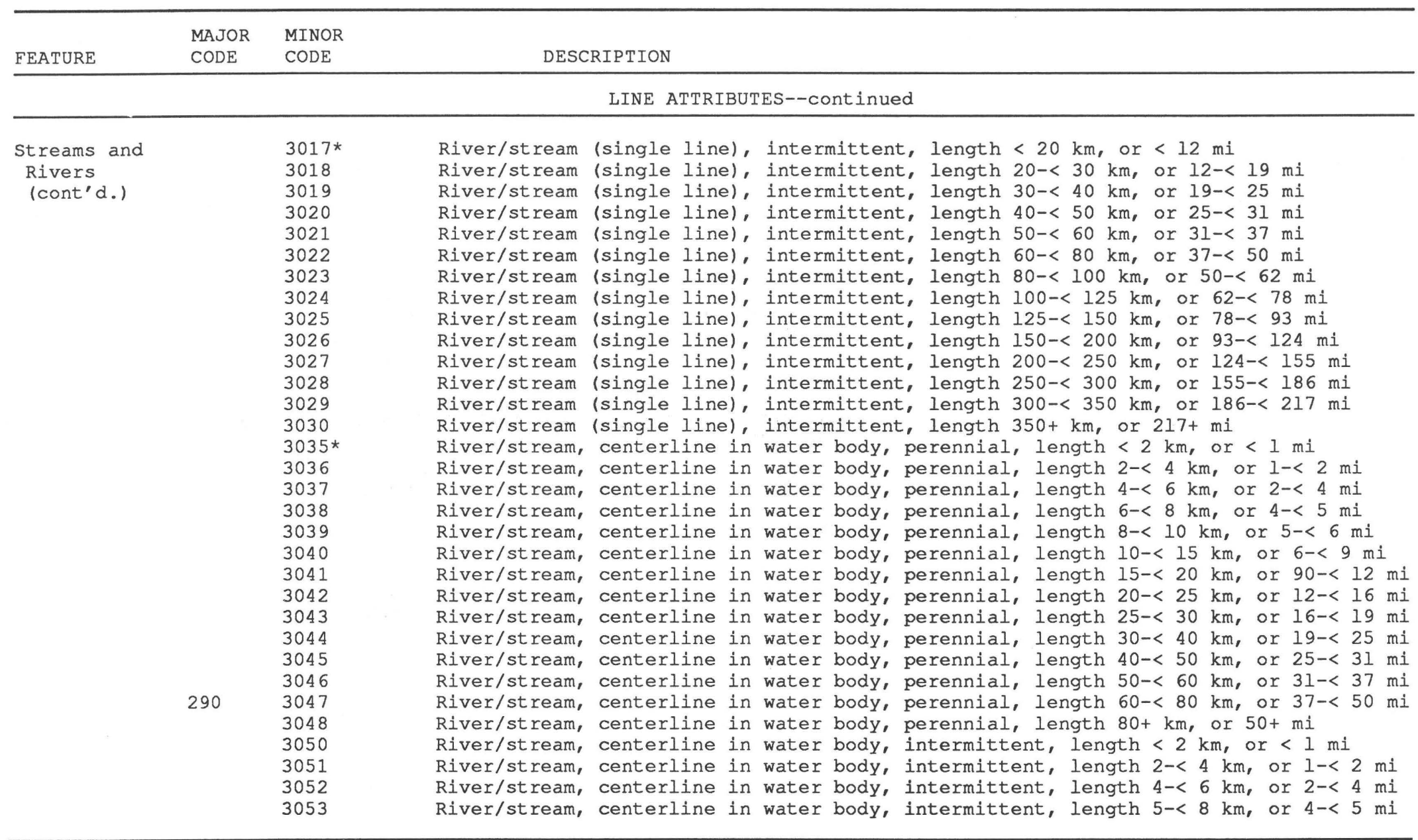

*This code was only used in the Alaskan drainage files. 


\begin{tabular}{|c|c|c|}
\hline FEATURE & $\begin{array}{l}\text { MAJOI } \\
\text { CODE }\end{array}$ & DESCRIPTION \\
\hline & & LINE ATTRIBUTES--continued \\
\hline $\begin{array}{l}\text { Streams and } \\
\text { Rivers } \\
\text { (cont'd.) }\end{array}$ & 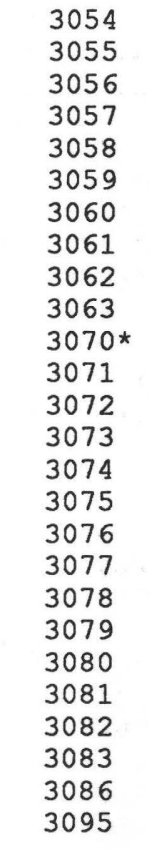 & $\begin{array}{l}\text { River/stream, centerline in water body, intermittent, length } 8-<10 \mathrm{~km} \text {, or } 5-<6 \mathrm{mi} \\
\text { River/stream, centerline in water body, intermittent, length } 10-<15 \mathrm{~km} \text {, or } 6-<9 \mathrm{mi} \\
\text { River/stream, centerline in water body, intermittent, length } 15-<20 \mathrm{~km} \text {, or } 9-<12 \mathrm{mi} \\
\text { River/stream, centerline in water body, intermittent, length } 20-<25 \mathrm{~km} \text {, or } 12-<16 \mathrm{mi} \\
\text { River/stream, centerline in water body, intermittent, length } 25-<30 \mathrm{~km} \text {, or } 16-<19 \mathrm{mi} \\
\text { River/stream, centerline in water body, intermittent, length } 30+\mathrm{km} \text { or } 19+\mathrm{mi} \\
\text { Braided stream, average width of braid } 6+\mathrm{km} \text {, or } 4+\mathrm{mi} \\
\text { Braided stream, average width of braid } 0-<2 \mathrm{~km} \text { or } 0-<1 \mathrm{mi} \\
\text { Braided stream, average width of braid } 2-<4 \mathrm{~km} \text {, or } 1-<2 \mathrm{mi} \\
\text { Braided stream, average width of braid } 4-<6 \mathrm{~km} \text {, or } 2-<4 \mathrm{mi} \\
\text { Canal, navigable, length }<\mathrm{km} \text { or }<1 \mathrm{mi} \\
\text { Canal, navigable, length } 1-<10 \mathrm{~km} \text { or } 1-<6 \mathrm{mi} \\
\text { Canal, navigable, length } 10-<20 \mathrm{~km} \text {, or } 6-<12 \mathrm{mi} \\
\text { Canal, navigable, length } 20-<40 \mathrm{~km} \text { or } 12-<25 \mathrm{mi} \\
\text { Canal, navigable, length } 40-<60 \mathrm{~km} \text {, or } 25-<37 \mathrm{mi} \\
\text { Canal, navigable, length } 60-<80 \mathrm{~km} \text { or } 37-<50 \mathrm{mi} \\
\text { Canal, navigable, length } 80+\mathrm{km} \text {, or } 50+\mathrm{mi} \\
\text { Canal, other, length } 1 \mathrm{~km} \text { or }<1 \mathrm{mi} \\
\text { Canal, other, length } 1-<10 \mathrm{~km} \text { or } 1-<6 \mathrm{mi} \\
\text { Canal, other, length } 10-<20 \mathrm{~km} \text { or } 6-<12 \mathrm{mi} \\
\text { Canal, other, length } 20-<40 \mathrm{~km} \text {, or } 12-<25 \mathrm{mi} \\
\text { Canal, other, length } 40-<60 \mathrm{~km} \text { or } 25-<37 \mathrm{mi} \\
\text { Canal, other, length } 60-<80 \mathrm{~km} \text { or } 37-<50 \mathrm{mi} \\
\text { Canal, other, length } 80+\mathrm{km} \text { or } 50+\mathrm{mi} \\
\text { Ditch (perennial) } \\
\text { Intercoastal waterway }\end{array}$ \\
\hline Water Bodies...290 & $\begin{array}{l}4000 \\
4001^{*} \\
4002 \\
4003\end{array}$ & $\begin{array}{l}\text { U.S. coastline including Great Lakes } \\
\text { Perennial water body, lake, reservoir, and island, length } 22 \mathrm{~km} \text {, or }<1 \mathrm{mi} \\
\text { Perennial water body, lake, reservoir, and island, length } 2-<4 \mathrm{~km} \text {, or } 1-<2 \mathrm{mi} \\
\text { Perennial water body, lake, reservoir, and island, length } 4-<6 \mathrm{~km} \text {, or } 2-<4 \mathrm{mi}\end{array}$ \\
\hline
\end{tabular}

*This code was only used in the Alaskan drainage files. 
APPENDIX E.--DLG Attribute Codes--continued

\begin{tabular}{|c|c|c|c|}
\hline \multirow[t]{2}{*}{ FEATURE } & $\begin{array}{l}\text { MAJOR } \\
\text { CODE }\end{array}$ & $\begin{array}{l}\text { MINOR } \\
\text { CODE }\end{array}$ & DESCRIPTION \\
\hline & & & LINE ATTRIBUTES--continued \\
\hline $\begin{array}{l}\text { Water Bodies } \\
\text { (cont'd.) }\end{array}$ & 290 & $\begin{array}{l}4004 \\
4005 \\
4006 \\
4007 \\
4008 \\
4009 \\
4010 \\
4011 \\
4012 \\
4013 \\
4014 \\
4021 \\
4022 \\
4023 \\
4024 \\
4025 \\
4026 \\
4027 \\
4028 \\
4029 \\
4030 \\
4031 \\
4032 \\
4033 \\
4034 \\
4040 \\
404 \\
404 \\
404 \\
404 \\
404 \\
404 \\
4050\end{array}$ & 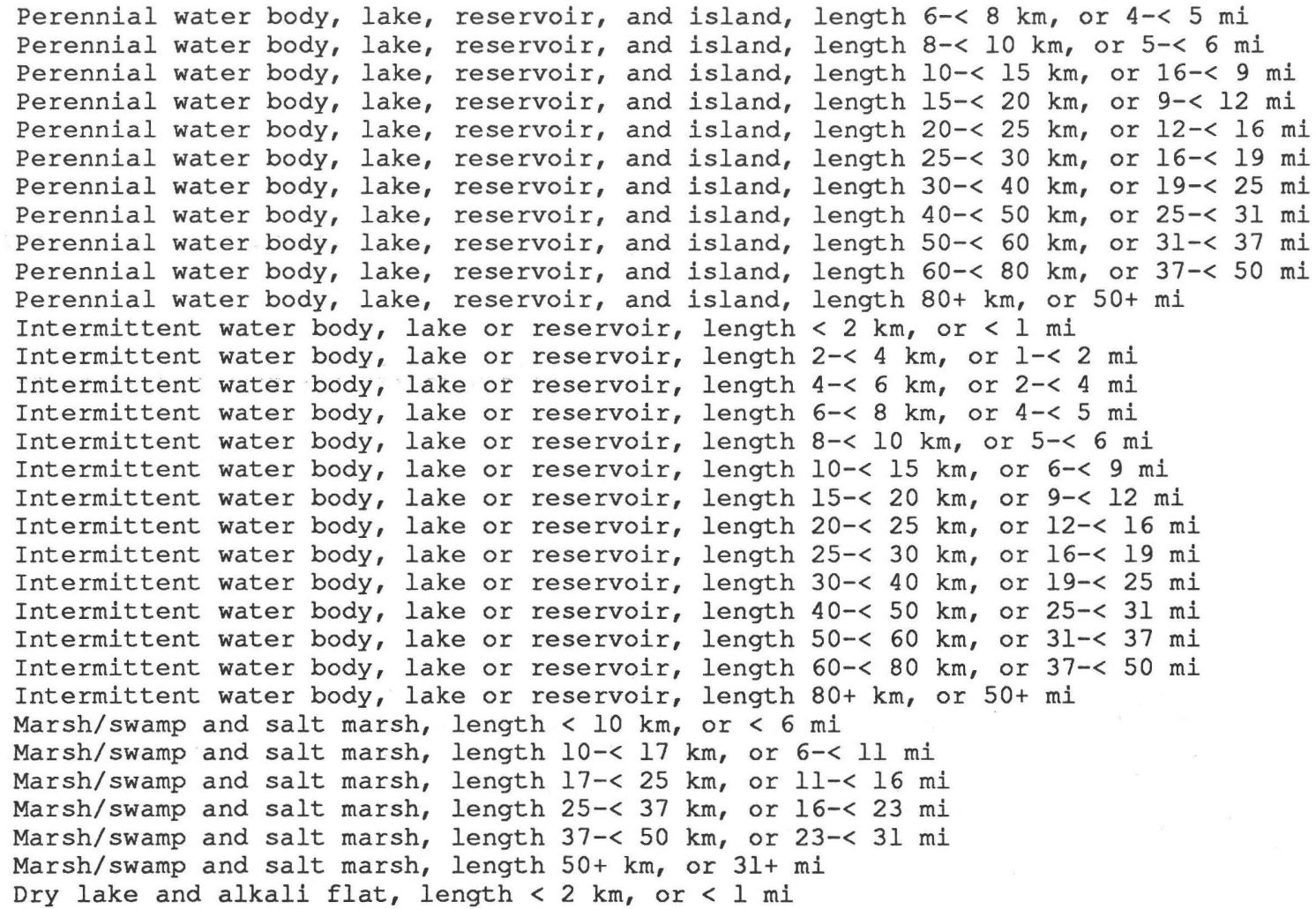 \\
\hline
\end{tabular}

*This code was only used in the Alaskan drainage files. 


\begin{tabular}{|c|c|c|c|}
\hline FEATURE & $\begin{array}{l}\text { MAJOR } \\
\text { CODE }\end{array}$ & $\begin{array}{l}\text { MINOR } \\
\text { CODE }\end{array}$ & DESCRIPTION \\
\hline & & & LINE ATTRIBUTES--continued \\
\hline $\begin{array}{l}\text { Water Bodies } \\
\text { (cont'd.) }\end{array}$ & & $\begin{array}{l}4051 \\
4052 \\
4053 \\
4060 \star \\
4061 \\
4062 \\
4063 \\
4064 \\
4065 \\
4066\end{array}$ & $\begin{array}{l}\text { Dry lake and alkali flat, length } 2-<4 \mathrm{~km} \text {, or } 1-<2 \mathrm{mi} \\
\text { Dry lake and alkali flat, length } 4-<6 \mathrm{~km} \text {, or } 2-<4 \mathrm{mi} \\
\text { Dry lake and alkali flat, length } 6+\mathrm{km} \text {, or } 4+\mathrm{mi} \\
\text { Glacier, length } 4 \mathrm{~km} \text {, or }<2 \mathrm{mi} \\
\text { Glacier, length } 4-<10 \mathrm{~km} \text {, or } 2-<6 \mathrm{mi} \\
\text { Glacier, length } 10-<17 \mathrm{~km} \text {, or } 6-<11 \mathrm{mi} \\
\text { Glacier, length } 17-<25 \mathrm{~km} \text {, or } 11-<16 \mathrm{mi} \\
\text { Glacier, length } 25-<37 \mathrm{~km} \text {, or } 16-<23 \mathrm{mi} \\
\text { Glacier, length } 37-<50 \mathrm{~km} \text {, or } 23-<31 \mathrm{mi} \\
\text { Glacier, length } 50+\mathrm{km} \text {, or } 31+\mathrm{mi}\end{array}$ \\
\hline $\begin{array}{l}\text { Roads and } \\
\text { Trails }\end{array}$ & 290 & $\begin{array}{l}5001 \\
5002 \\
5003 \\
5004 \\
5005 \\
5006 \\
5007 \\
5008 \\
5009 \\
5010 \\
5013 \\
5014 \\
5015 \\
5016 \\
5017 \\
5018 \\
5019\end{array}$ & $\begin{array}{l}\text { Interstate } \\
\text { Major U.S., limited access, divided } \\
\text { Major state, limited access, divided } \\
\text { Major other, limited access, divided } \\
\text { Toll road } \\
\text { Interstate connector } \\
\text { Limited access, divided connector } \\
\text { Toll connector } \\
\text { Interstate, under construction } \\
\text { Interstate, proposed } \\
\text { Minor U.S., limited access, } 310 \mathrm{~km}(500 \mathrm{mi}) \text { and longer } \\
\text { U.S. non-limited access, } 310 \mathrm{~km}(500 \mathrm{mi}) \text { and longer } \\
\text { Minor U.S. limited access, less than } 310 \mathrm{~km}(500 \mathrm{mi}) \\
\text { U.S. non-limited access, less than } 310 \mathrm{~km}(500 \mathrm{mi}) \\
\text { Other minor U.S. limited access } \\
\text { Other U.s.2. } \\
\text { Other minor State primary, limited access }\end{array}$ \\
\hline
\end{tabular}

*This code was only used in the Alaskan drainage files.

Redundant entry used to provide additional information.

${ }^{2} \mathrm{U} . \mathrm{S}$. business, alternate, bypass, and routes paralleling U.S. or Interstate routes within $10 \mathrm{to} 25 \mathrm{~km}$. 
APPENDIX E.--DLG Attribute Codes--continued

\begin{tabular}{|c|c|c|c|}
\hline FEATURE & $\begin{array}{l}\text { MAJOR } \\
\text { CODE }\end{array}$ & $\begin{array}{l}\text { MINOR } \\
\text { CODE }\end{array}$ & DESCRIPTION \\
\hline & & & LINE ATTRIBUTES--continued \\
\hline $\begin{array}{l}\text { Roads and } \\
\text { Trails } \\
\text { (cont'd.) }\end{array}$ & & $\begin{array}{l}5020 \\
5021 \\
5022 \\
5023 \\
5024 \\
5028 \\
5031 \\
5041 \\
5061 \\
5062\end{array}$ & $\begin{array}{l}\text { Other State primary } \\
\text { Minor U.S. parallel, within } 10 \mathrm{~km} \text { ( } 6 \mathrm{mi}) \\
\text { U.S. parallel, within } 10 \mathrm{~km}(6 \mathrm{mi}) \\
\text { Minor State parallel, within } 10 \mathrm{~km} \text { ( } 6 \mathrm{mi}) \\
\text { State parallel, within } 10 \mathrm{~km}(6 \mathrm{mi}) \\
\text { State secondary (all weather, hard surface) } \\
\text { Light duty (all weather, improved) } \\
\text { Unimproved (fair or dry weather) } \\
\text { Tunnel, road } \\
\text { Ferry, auto }\end{array}$ \\
\hline Railroads.... & .290 & $\begin{array}{l}5071 \\
5072 \\
5073 \\
5074 \\
5075 \\
5078 \\
5079 \\
5080\end{array}$ & $\begin{array}{l}\text { Class 1, category A, main line } \\
\text { Class 1, category B, main line } \\
\text { Class 1, category A, branch line } \\
\text { Class 1, category B, branch line } \\
\text { Other railroad } \\
\text { Tunnel, railroad } \\
\text { Ferry, railroad } \\
\text { Class } 1 \text {, category A, main-line connector }{ }^{1}\end{array}$ \\
\hline $\begin{array}{l}\text { Political } \\
\text { Boundaries }\end{array}$ & 290 & $\begin{array}{l}6000 \\
6001 \\
6002 \\
6005 \\
6006 \\
6009 \\
6010 \\
6011 \\
6012 \\
6014\end{array}$ & $\begin{array}{l}\text { International treaty line } \\
\text { National (land) } \\
\text { National (water) } \\
\text { State/provincial (land) } \\
\text { State/provincial (water) } \\
\text { County, parish, Alaskan borough, or large independent city (land) } \\
\text { County, parish, Alaskan borough, or large independent city (water) } \\
\text { Corporate limit ( } 1 \text { million and over population) } \\
\text { Corporate limit ( } 1 / 2 \text { to less than I million population) } \\
\text { Small independent city (usually not shown as a county) }\end{array}$ \\
\hline
\end{tabular}

${ }^{1}$ Redundant entry used to provide additional information.

${ }^{2}$ Maritime boundary areas are usually closed by unattributed arbitrary extension lines. 


\begin{tabular}{|c|c|c|c|}
\hline FEATURE & \multicolumn{2}{|c|}{ MAJOR MINOR } & DESCRIPTION \\
\hline
\end{tabular}

Administrative $290 \quad 6021$

Boundaries 6022

6023

6024

6025

6026

6027

6028

6028

6029

6030

6031

6032

6033

6034

6034

6035

6037

6038

6039

6040

6040

6041

6043

6044

6045

6045

6051

6053

6054

6055

6056

6056

6057

6059

6060
National park, length at longest dimension $0-<2 \mathrm{~km}$, or $0-<1 \mathrm{mi}$

National park, length at longest dimension $2-<8 \mathrm{~km}$, or $1-<5 \mathrm{mi}$

National park, length at longest dimension $8-<14 \mathrm{~km}$, or $5-<9 \mathrm{mi}$

National park, length at longest dimension $4-<20 \mathrm{~km}$, or $9-<12 \mathrm{mi}$

National park, length at longest dimension $20+\mathrm{km}$, or $12+\mathrm{mi}$

National monument, length at longest dimension $0-<2 \mathrm{~km}$, or $0-<1 \mathrm{mi}$

National monument, length at longest dimension $2-<8 \mathrm{~km}$, or $1-<5 \mathrm{mi}$

National monument, length at longest dimension $8-<14 \mathrm{~km}$, or $5-<9 \mathrm{mi}$

National monument, length at longest dimension $14-<20 \mathrm{~km}$ or $9-<12 \mathrm{mi}$

National monument, length at longest dimension $20+\mathrm{km}$, or $12+\mathrm{mi}$

National seashore or lakeshore, length at longest dimension $0-<2 \mathrm{~km}$, or $0-<1 \mathrm{mi}$

National seashore or lakeshore, length at longest dimension $2-<8 \mathrm{~km}$, or $1-<5 \mathrm{mi}$

National seashore or lakeshore, length at longest dimension $8-<14 \mathrm{~km}$, or $5-<9 \mathrm{mi}$

National seashore or lakeshore, length at longest dimension $4-<20 \mathrm{~km}$, or $9-<12 \mathrm{mi}$

National seashore or lakeshore, length at longest dimension $20+\mathrm{km}$, or $12+\mathrm{mi}$

National recreation area, length at longest dimension $0-<2 \mathrm{~km}$, or $0-<1 \mathrm{mi}$

National recreation area, length at longest dimension $2-<8 \mathrm{~km}$, or $1-<5 \mathrm{mi}$

National recreation area, length at longest dimension $8-<14 \mathrm{~km}$, or $5-<9 \mathrm{mi}$

National recreation area, length at longest dimension $14-<20 \mathrm{~km}$, or $9-<12 \mathrm{mi}$

National recreation area, length at longest dimension $20+\mathrm{km}$, or $12+\mathrm{mi}$

National wilderness area, length at longest dimension $0-<2 \mathrm{~km}$, or $0-<1 \mathrm{mi}$

National wilderness area, length at longest dimension $2-<8 \mathrm{~km}$, or $1-<5 \mathrm{mi}$

National wilderness area, length at longest dimension $8-<14 \mathrm{~km}$, or $5-<9 \mathrm{mi}$

National wilderness area, length at longest dimension $14-<20 \mathrm{~km}$, or $9-<12 \mathrm{mi}$

National wilderness area, length at longest dimension $20+\mathrm{km}$, or $12+\mathrm{mi}$

National forest, length at longest dimension $0-<2 \mathrm{~km}$, or $0-<1 \mathrm{mi}$

National forest, length at longest dimension $2-<8 \mathrm{~km}$, or $1-<5 \mathrm{mi}$

National forest, length at longest dimension $8-<14 \mathrm{~km}$, or $5-<9 \mathrm{mi}$

National forest, length at longest dimension $14-<20 \mathrm{~km}$, or $9-<12 \mathrm{mi}$

National forest, length at longest dimension $20+\mathrm{km}$, or $12+\mathrm{mi}$

National grassland, length at longest dimension $0-<2 \mathrm{~km}$, or $0-<1 \mathrm{mi}$

National grassland, length at longest dimension $2-<8 \mathrm{~km}$, or $1-<5 \mathrm{mi}$

National grassland, length at longest dimension $8-<14 \mathrm{~km}$, or $5-<9 \mathrm{mi}$

National grassland, length at longest dimension $14-<20 \mathrm{~km}$, or $9-<12 \mathrm{mi}$

National grassland, length at longest dimension $20+\mathrm{km}$, or $12+\mathrm{mi}$ 
APPENDIX E.--DLG Attribute Codes--continued

\begin{tabular}{|c|c|c|c|}
\hline FEATURE & $\begin{array}{l}\text { MAJOR } \\
\text { CODE }\end{array}$ & $\begin{array}{l}\text { MINOR } \\
\text { CODE }\end{array}$ & DESCRIPTION \\
\hline & & & LINE ATTRIBUTES--continued \\
\hline $\begin{array}{l}\text { Administrative } \\
\text { Boundaries } \\
\text { (cont'd.) }\end{array}$ & 290 & $\begin{array}{l}6061 \\
6062 \\
6063 \\
6064 \\
6065 \\
6066 \\
6067 \\
6068 \\
6069 \\
6070 \\
6081 \\
6082 \\
6087 \\
6088 \\
6089 \\
6090 \\
6091 \\
6092 \\
6093 \\
6094 \\
6095 \\
6097\end{array}$ & $\begin{array}{l}\text { National wildlife refuge, length at longest dimension } 0-<2 \mathrm{~km} \text {, or } 0-<1 \mathrm{mi} \\
\text { National wildlife refuge, length at longest dimension } 2-<8 \mathrm{~km} \text {, or } 1-<5 \mathrm{mi} \\
\text { National wildlife refuge, length at longest dimension } 8-<14 \mathrm{~km} \text {, or } 5-<9 \mathrm{mi} \\
\text { National wildlife refuge, length at longest dimension } 14-<20 \mathrm{~km} \text {, or } 9-<12 \mathrm{mi} \\
\text { National wildlife refuge, length at longest dimension } 20+\mathrm{km} \text {, or } 12+\mathrm{mi} \\
\text { Federal Indian reservation, length at longest dimension } 0-<2 \mathrm{~km} \text {, or } 0-<1 \mathrm{mi} \\
\text { Federal Indian reservation, length at longest dimension } 2-<8 \mathrm{~km} \text {, or } 1-<5 \mathrm{mi} \\
\text { Federal Indian reservation, length at longest dimension } 8-<14 \mathrm{~km} \text {, or } 5-<9 \mathrm{mi} \\
\text { Federal Indian reservation, length at longest dimension } 14-<20 \mathrm{~km} \text {, or } 9-<12 \mathrm{mi} \\
\text { Federal Indian reservation, length at longest dimension } 20+\mathrm{km} \text {, or } 12+\mathrm{mi} \\
\text { Federal Military reservation, areas of l-< } 405 \text { ha, or } 1-<1000 \text { acres } \\
\text { Federal Military reservation, areas of } 405+\text { ha, or } 1000+\text { acres } \\
\text { National park, closure line } \\
\text { National monument, closure line } \\
\text { National seashore or lakeshore, closure line } \\
\text { National recreation area, closure line } \\
\text { National wilderness area, closure line } \\
\text { National forest, closure line } \\
\text { National grassland, closure line } \\
\text { National wildlife refuge, closure line } \\
\text { Indian reservation, closure line } \\
\text { Military reservation, closure line }\end{array}$ \\
\hline $\begin{array}{l}\text { Cultural } \\
\text { Features }\end{array}$ & 290 & $\begin{array}{l}7001 \\
7002 \\
7020\end{array}$ & $\begin{array}{l}\text { Commmercial airfield } \\
\text { Military airfield } \\
\text { Alaska pipeline }\end{array}$ \\
\hline
\end{tabular}


This appendix illustrates the procedure for converting internal file coordinates to ground planimetric reference coordinates. The formulas for this conversion are as follows:

$$
\begin{aligned}
& X=A 1 x+A 2 y+A 3 \\
& Y=A 1 y-A 2 x+A 4
\end{aligned}
$$

where $\mathrm{X}$ and $\mathrm{Y}$ are the ground planimetric coordinate values and $\mathrm{x}$ and $\mathrm{y}$ are the internal file coordinates.

The parameters for these formulas (A1, A2, A3, and A4) are contained in Header Record B, as doubleprecision floating-point numbers.

This example converts four coordinate pairs from internal file coordinates to ground planimetric coordinate values (Albers Equal-Area Conic projection). The parameters are as follows:

$$
\begin{aligned}
& \mathrm{A} 1=50.325538142 \\
& \mathrm{~A} 2=6.9275199981 \\
& \mathrm{~A} 3=-1185878.9723 \\
& \mathrm{~A} 4=1314164.3401
\end{aligned}
$$

The internal file coordinates to be converted are:

\begin{tabular}{lrr} 
& \multicolumn{1}{c}{} & \multicolumn{1}{c}{} \\
1st pair & -11238 & -6583 \\
2d pair & -10405 & 6583 \\
3d pair & 10405 & 6583 \\
4th pair & 11238 & -6583
\end{tabular}

The calculation to determine the ground planimteric coordinates for the first pair are as follows:

$$
\begin{aligned}
X & =(50.325538142)(-11238)+(6.9275199981)(-6583)+(-1185878.9723) \\
& =-1797041.23 \\
Y & =(50.325538142)(-6583)-(6.9275199981)(-11238)+(1314164.3401) \\
& =1060722.79
\end{aligned}
$$

The resulting $x, y$ coordinate values for the four pairs given above are as follows:

$\begin{array}{lrr}\text { 1st pair } & -1,797,041.23 & 1,060,722.79 \\ \text { 2d pair } & -1,663,912.33 & 1,717,538.20 \\ \text { 3d pair } & -616,637.88 & 1,573,376.51 \\ \text { 4th pair } & -665,924.44 & 905,019.86\end{array}$


APPENDIX G.--Sample DLG data file (Standard Distribution Format)

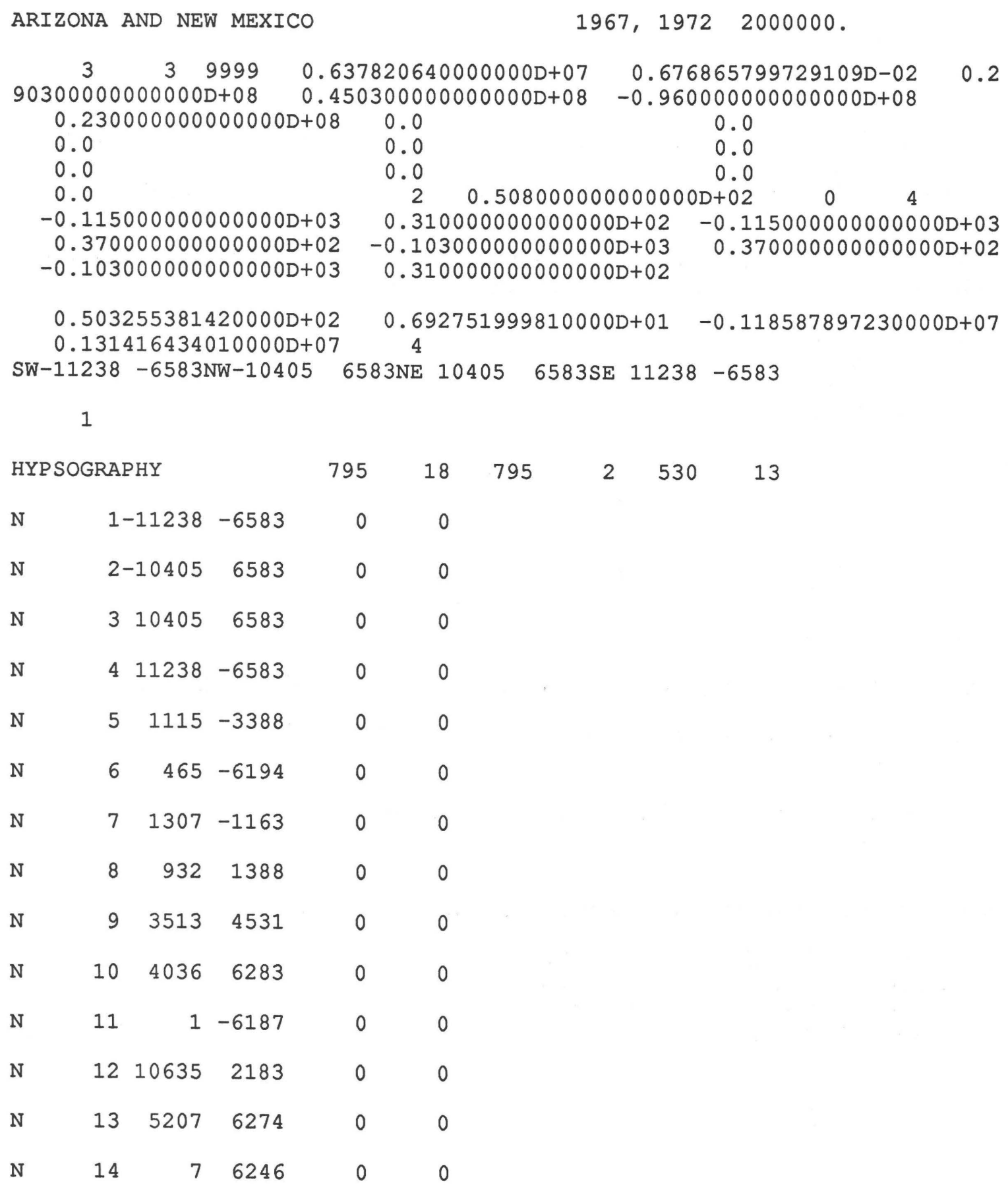


APPENDIX G.--Sample DLG data file (Standard Distribution Format)--continued

$\begin{array}{cccccc}\mathrm{N} & 15-5201 & 6334 & 0 & 0 \\ \mathrm{~N} & 16-10031 & 3973 & 0 & 0 \\ \mathrm{~N} & 17-10023 & -857 & 0 & 0 \\ \mathrm{~N} & 18 & 10402 & 6519 & 0 & 0 \\ \mathrm{~A} & 1 & -96 & 5417 & 1 & 0 \\ & 0 & 0 & & & \end{array}$

$\begin{array}{rrrrrrrrr}\text { A } & 2 & 287 & 3013 & 0 & 0 & & & \\ \text { I } & 1 & 5 & 6 & 2 & 2 & 334 & 1 & 0\end{array}$

\begin{tabular}{|c|c|c|c|c|c|c|c|c|c|c|c|}
\hline 11 & & 02 & 99 & 96 & 11 & 0 & 423 & 83 & -3428 & 75 & -5 \\
\hline & & 62 & & 62 & & & & 62 & & 56 & \\
\hline & & 6 & 12 & 41 & & 38 & & 35 & & 33 & \\
\hline 0 & 9 & 025 & 49 & 017 & & 1007 & & 996 & & 91 & \\
\hline 86 & & 982 & 12 & 79 & & 977 & & 977 & & 76 & \\
\hline 973 & & 972 & - & 3 & & 980 & & 987 & & 97 & \\
\hline 10 & & 1 & & & & & & & & & \\
\hline 1 & 5 & 8 & -3 & 2 & - & 4 & - & 79 & - & 38 & 1 \\
\hline 29 & 9 & 288 & -3982 & 1286 & -4 & 1287 & -4 & 1287 & -4 & 1288 & - \\
\hline 287 & 5 & 1285 & -4070 & 1285 & -4 & 1286 & -4 & 1284 & -4 & 8 & \\
\hline 128 & & 1283 & & 1281 & & 1278 & & 12 & & & \\
\hline 1291 & & 1296 & -4 & 13 & & 1309 & & 1325 & & & \\
\hline 13 & & 13 & & & & & & & & & \\
\hline 1501 & -4 & .510 & -44 & 1513 & -4 & 1518 & -4 & 1521 & -4 & 1531 & - \\
\hline 15 & 4 & 550 & -4595 & 1547 & -4 & 1538 & -4 & 1528 & -4 & 1510 & -4 \\
\hline 4 & -4666 & 487 & -46 & 1479 & -4 & 1475 & -4 & 1469 & -4 & 1462 & -4 \\
\hline 4 & -4729 & 19 & -47 & 1442 & & 1429 & - & 7 & - & 1401 & - \\
\hline 1386 & & 1374 & -47 & 1360 & & 1344 & - & 5 & & 9 & - \\
\hline 1296 & & 6 & 9 & 1278 & & 1267 & & 4 & & 1 & \\
\hline & & 87 & & 1 & & 1162 & & 9 & & & \\
\hline 1127 & -4 & 1121 & -4831 & 1110 & -4835 & 1098 & -4839 & 1089 & -4842 & 1079 & -4839 \\
\hline 1071 & -4834 & 1060 & -4825 & 1055 & -4817 & 1050 & -4799 & 1040 & -4784 & 1029 & -4770 \\
\hline 1021 & -4760 & 1006 & -4744 & 992 & -4727 & 972 & 0 & 49 & -4690 & 939 & -4678 \\
\hline 930 & -4665 & 925 & 46 & 923 & -4640 & 920 & 27 & 911 & $-4 t$ & 910 & -4594 \\
\hline 9 & & 899 & -45 & 891 & -45 & 880 & -4 & 370 & -4 & 59 & \\
\hline 8 & -4536 & 837 & -4535 & 827 & -4534 & 816 & -4538 & 804 & -4539 & 793 & -45 \\
\hline
\end{tabular}

$290 \quad 2017$

$\begin{array}{lllllllll}\text { L } & 2 & 5 & 7 & 2 & 2 & 364 & 1 & 0\end{array}$ 
APPENDIX G.--Sample DLG data file (Standard Distribution Format)--continued

\begin{tabular}{|c|c|c|c|c|c|c|c|c|c|c|c|}
\hline 1115 & -3388 & 1124 & -3380 & 1131 & -3377 & 1142 & -3376 & 1147 & -3376 & 1150 & -3374 \\
\hline 1157 & -3369 & 1163 & -3361 & 1168 & -3353 & 1170 & -3346 & 1172 & -3336 & 1174 & -3328 \\
\hline 1176 & -3323 & 1181 & -3320 & 1188 & -3317 & 1198 & -3312 & 1204 & -3310 & 1210 & -3306 \\
\hline 1215 & -3301 & 1218 & -3294 & 1217 & -3283 & 1213 & -3269 & 1212 & -3255 & 1206 & -3240 \\
\hline 1197 & -3219 & 1194 & -3204 & 1195 & -3197 & 1196 & -3186 & 1197 & -3176 & 1204 & -3166 \\
\hline 1211 & -3152 & 1218 & -3138 & 1230 & -3128 & 1237 & -3116 & 1244 & -3101 & 1248 & -3090 \\
\hline 1250 & -3084 & 1249 & -3073 & 1246 & -3063 & 1239 & -3045 & 1237 & -3042 & 1238 & -3034 \\
\hline 1246 & -3020 & 1250 & -3005 & 1251 & -2994 & 1250 & -2985 & 1251 & -2977 & 1247 & -2973 \\
\hline 1241 & -2964 & 1231 & -2960 & 1225 & -2952 & 1216 & -2940 & 1212 & -2933 & 1208 & -2928 \\
\hline 1195 & -2910 & 1192 & -2900 & 1188 & -2892 & 1192 & -2890 & 1201 & -2890 & 1211 & -2892 \\
\hline & & & 1322 & & 1316 & 1140 & 1312 & 1146 & 1307 & -1163 & \\
\hline
\end{tabular}

$290 \quad 2017$

$\begin{array}{lllllllll}\text { L } & 3 & 9 & 8 & 2 & 2 & 461 & 1 & 0\end{array}$

$\begin{array}{llllllllllll}3513 & 4531 & 3504 & 4525 & 3494 & 4520 & 3488 & 4515 & 3482 & 4506 & 3473 & 4497\end{array}$

$\begin{array}{llllllllllll}3468 & 4480 & 3464 & 4470 & 3460 & 4462 & 3457 & 4451 & 3454 & 4439 & 3451 & 4432\end{array}$

$\begin{array}{llllllllllll}3446 & 4419 & 3443 & 4401 & 3436 & 4378 & 3431 & 4366 & 3426 & 4356 & 3421 & 4344\end{array}$

$\begin{array}{llllllllllll}3405 & 4336 & 3379 & 4331 & 3362 & 4326 & 3340 & 4317 & 3330 & 4309 & 3316 & 4300\end{array}$

$\begin{array}{llllllllllll}3309 & 4290 & 3303 & 4279 & 3290 & 4265 & 3285 & 4259 & 3276 & 4246 & 3266 & 4232\end{array}$

$\begin{array}{llllllllllll}3248 & 4225 & 3239 & 4222 & 3225 & 4217 & 3212 & 4215 & 3191 & 4215 & 3173 & 4218\end{array}$

$\begin{array}{llllllllllll}3155 & 4221 & 3133 & 4223 & 3124 & 4220 & 3108 & 4213 & 3093 & 4208 & 3075 & 4207\end{array}$

$\begin{array}{llllllllllll}3057 & 4208 & 3035 & 4209 & 3018 & 4210 & 2993 & 4209 & 2969 & 4206 & 2954 & 4197\end{array}$

$\begin{array}{lllllllllll}\ldots \ldots \ldots & 961 & 1412 & 951 & 1399 & 942 & 1393 & 936 & 1390 & 932 & 1388\end{array}$

$290 \quad 2017$

$\begin{array}{lllllllll}\text { L } & 4 & 10 & 9 & 2 & 2 & 229 & 1 & 0\end{array}$

$\begin{array}{llllllllllll}4036 & 6283 & 4028 & 6280 & 4022 & 6276 & 4012 & 6271 & 4005 & 6269 & 3995 & 6270\end{array}$

$\begin{array}{llllllllllll}3987 & 6270 & 3975 & 6274 & 3970 & 6272 & 3965 & 6267 & 3960 & 6258 & 3960 & 6252\end{array}$

$\begin{array}{llllllllllll}3962 & 6242 & 3965 & 6227 & 3961 & 6224 & 3955 & 6221 & 3947 & 6216 & 3953 & 6213\end{array}$

$\begin{array}{llllllllllll}3962 & 6207 & 3969 & 6201 & 3979 & 6193 & 3981 & 6188 & 3982 & 6180 & 3986 & 6172\end{array}$

$\begin{array}{llllllllllll}3990 & 6160 & 3993 & 6155 & 3996 & 6148 & 4004 & 6137 & 4005 & 6125 & 4006 & 6111\end{array}$

$\begin{array}{llllllllllll}4007 & 6106 & 4010 & 6098 & 4011 & 6090 & 4008 & 6089 & 4003 & 6087 & 3998 & 6084\end{array}$

$\begin{array}{llllllllllll}3990 & 6078 & 3984 & 6074 & 3980 & 6067 & 3976 & 6065 & 3970 & 6063 & 3950 & 6054\end{array}$

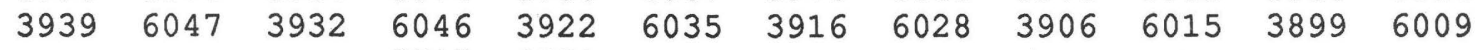

$290 \quad 2017$

$\begin{array}{lllllllll}\text { L } & 5 & 12 & 6 & 1 & 2 & 125 & 0 & 0\end{array}$

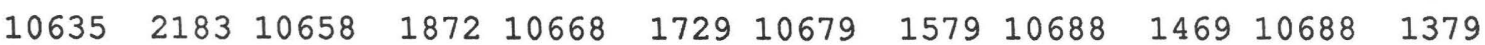

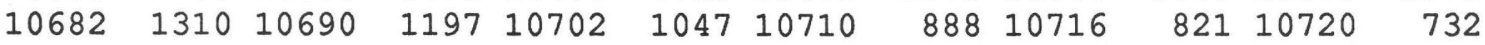

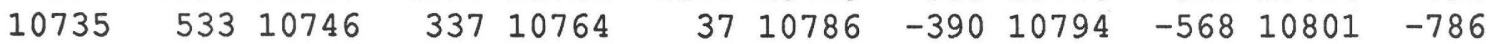


APPENDIX G.--Sample DLG data file (Standard Distribution Format)--continued

\begin{tabular}{|c|c|c|c|c|c|c|c|c|c|c|c|}
\hline 810 & -944 & 10820 & -1133 & 10822 & -1307 & 10828 & -1399 & 10834 & -1499 & 10847 & -1778 \\
\hline 59 & -1986 & 10869 & -2186 & 10877 & -2330 & 10892 & -2527 & 10904 & -2707 & 10918 & -2953 \\
\hline 10934 & -3208 & 10944 & -3383 & 10958 & -3621 & 10974 & -3868 & 10988 & -4085 & 11002 & -4334 \\
\hline 005 & -4403 & 10401 & -4442 & 9737 & -4473 & 9539 & -4480 & 9366 & -4489 & 9237 & -4498 \\
\hline 146 & -4505 & 9066 & -4509 & 8895 & -4520 & 8761 & -4530 & 8562 & -4535 & 8432 & -4 \\
\hline $8<$ & -4546 & 8019 & -4 & 79 & -4 & 7853 & -4 & 16 & -4 & 32 & -2 \\
\hline & -4572 & 7607 & -4575 & 7531 & -4580 & 7402 & -4587 & 7294 & -4591 & 7151 & - \\
\hline 6944 & -4608 & 6706 & -4614 & 6393 & -4625 & 6222 & -4630 & 5917 & -4644 & 5728 & -4650 \\
\hline 5477 & -4661 & 5086 & -4668 & 4689 & -4680 & 4431 & -4683 & 4412 & -4 & 4400 & 1702 \\
\hline 4376 & -4719 & 4372 & -4722 & 4370 & -4733 & 4373 & -4744 & 4390 & -4753 & 404 & -4753 \\
\hline 4417 & -4760 & 4414 & -4786 & 4406 & -4796 & 4401 & -4813 & 4402 & -4837 & 4403 & -4 \\
\hline 4404 & -4865 & 4403 & -4879 & 4395 & -4886 & 4388 & -4890 & 4384 & -4894 & 4384 & $-4 \varsigma$ \\
\hline 4395 & -4927 & 4399 & -4936 & 4410 & -4946 & 4418 & -4964 & 4424 & -4978 & 4421 & -499 \\
\hline 4412 & -4999 & 4410 & -5002 & 4421 & -5019 & 4434 & -5027 & 4438 & -5050 & 4448 & -507 \\
\hline 4452 & -5084 & 4455 & -5088 & 4470 & -5093 & 4478 & -5097 & 4490 & -5103 & 4500 & -5108 \\
\hline 4506 & -5113 & 4527 & -5120 & 4544 & -5124 & 4563 & -5130 & 4569 & -5133 & 4579 & -5143 \\
\hline 4587 & -5159 & 4227 & -5162 & 3593 & -5182 & 3138 & -5195 & 2577 & -5202 & 2122 & -520 \\
\hline 1622 & -5212 & 1471 & -5212 & 1473 & -6186 & 881 & -6190 & 465 & -6194 & & \\
\hline
\end{tabular}

$\begin{array}{llllll}465 & -6194 & 176 & -6193 & 1 & -6187\end{array}$

$\begin{array}{lrrrrrrrrrrr}\text { I } & 7 & 15 & 14 & 1 & 2 & 16 & 0 & 0 & & \\ -5201 & 6334 & -4824 & 6327 & -4194 & 6312 & -3442 & 6299 & -2851 & 6288 & -2609 & 6286 \\ -2587 & 6283 & -2578 & 6281 & -2560 & 6276 & -2544 & 6270 & -2535 & 6262 & -2517 & 6262 \\ -2413 & 6263 & -1728 & 6251 & -603 & 6245 & 7 & 6246 & & & & \end{array}$

$\begin{array}{lllllllll}\text { L } & 8 & 17 & 16 & 1 & 2 & 421 & 0 & 0\end{array}$

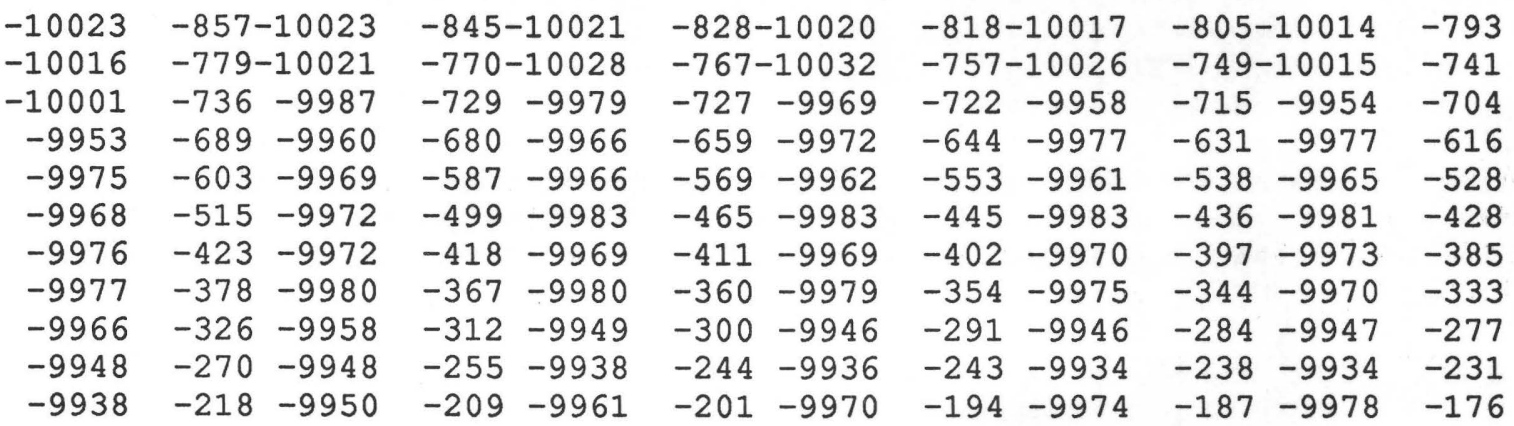

..........10031 3973

$\begin{array}{lllllllll}\text { I } & 9 & 16 & 15 & 1 & 2 & 158 & 0 & 0\end{array}$ 
APPENDIX G.--Sample DLG data file (Standard Distribution Format)--continued

\begin{tabular}{|c|c|c|}
\hline-10031 & $3973-10032$ & $3984-10034$ \\
\hline-10023 & $4038-10016$ & $4043-10011$ \\
\hline-9974 & $4075-9978$ & $4084-9992$ \\
\hline-10033 & $4145-10037$ & $4158-10044$ \\
\hline-10077 & $4231-10078$ & $4248-10079$ \\
\hline-10093 & $4326-10095$ & $4335-10098$ \\
\hline-10076 & $4396-10068$ & $4401-10059$ \\
\hline-10058 & $4460-10073$ & $4486-10073$ \\
\hline-10053 & $4565-10039$ & $4578-10018$ \\
\hline-9908 & $4649-9894$ & $4659-9881$ \\
\hline 50 & $4642-9842$ & $4639-9824$ \\
\hline 742 & $\begin{array}{lll}4677 & -9720\end{array}$ & $4674-9699$ \\
\hline 597 & $4601-9573$ & $4608-9563$ \\
\hline-9513 & $4613-9504$ & $4620-9494$ \\
\hline 60 & $4646-9436$ & $4644-9419$ \\
\hline-9394 & $4600-9390$ & $4593-9388$ \\
\hline 358 & $4566-9351$ & $4560-9344$ \\
\hline-9325 & $\begin{array}{lll}4491 & -9327\end{array}$ & $4474-9328$ \\
\hline 9294 & $4409-9271$ & $4386-9250$ \\
\hline-9218 & $4345-9207$ & $4341-9195$ \\
\hline 36 & $4349-9122$ & $4352-9110$ \\
\hline-9043 & -9033 & $4377-9022$ \\
\hline & $4484-8990$ & $4513-8982$ \\
\hline & $4591-8942$ & $4605-892$ \\
\hline & $4689-8875$ & $4700-8869$ \\
\hline & 4738 & $4762-8827$ \\
\hline & 6418 & \\
\hline
\end{tabular}

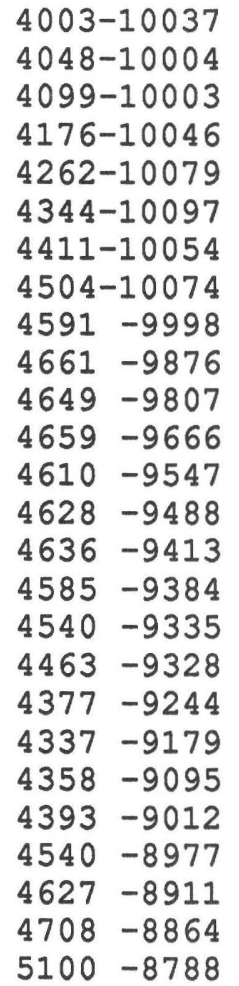

4027-10031

$4062-9980$

4119-10029

4203-10062

4287-10089

4372-10085

4439-10056

4543-10063

$4618-9925$

$4652-9856$

$4668-9768$

$\begin{array}{lll}4615 & -9617\end{array}$

$4609-9518$

$\begin{array}{lll}4637 & -9477\end{array}$

$\begin{array}{lll}4622 & -9398\end{array}$

$4574-9366$

$4520-9326$

$4441-9315$

$4367-9228$

$4337-9148$

$\begin{array}{lll}4359 & -9057\end{array}$

$4447-9000$

$4564-8961$

$4658-8895$

$\begin{array}{lll}4719 & -8848\end{array}$

$\begin{array}{lll}6255 & -8754\end{array}$
4035

4063

4134

4212

4305

4387

4449

4554

4637

4646

4676

4604

4611

4642

4611

4571

4508

4433

4353

4342

4361

4465

4578

4674

4728

6485

$\begin{array}{rrrrrrr}7 & 6246 & 391 & 6245 & 1156 & 6251 & 1872 \\ 3629 & 6289 & 3676 & 6290 & 3684 & 6289 & 3692 \\ 3712 & 6273 & 3719 & 6270 & 3744 & 6271 & 3858\end{array}$

$6258 \quad 2457$ 62863700 $6276 \quad 4036$

6264

$6283 \quad 3706$

6269

6283

6278

I

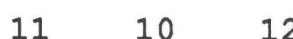

26

0

$\begin{array}{rrrrrrrrrrrr}4036 & 6283 & 4303 & 6291 & 4628 & 6299 & 5063 & 6316 & 5443 & 6328 & 6150 & 6349 \\ 6791 & 6375 & 7331 & 6399 & 7927 & 6426 & 8231 & 6439 & 8680 & 6468 & 9248 & 6502 \\ 9900 & 6547 & 10261 & 6570 & 10406 & 6581 & 10452 & 5824 & 10479 & 5460 & 10425 & 5459 \\ 10456 & 4873 & 10483 & 4594 & 10494 & 4465 & 10508 & 4183 & 10528 & 3917 & 10538 & 3716 \\ 10604 & 2704 & 10635 & 2183 & & & & & & & & \end{array}$

$\begin{array}{lllllllll}\text { I } & 12 & 11 & 17 & 1 & 2 & 333 & 0 & 0\end{array}$

$1-6187-1739-6193-3872-6160-3919-6144-8111-4445-10703-3356$ $-10696-3344-10694-3333-10691-3324-10687-3315-10681-3305-10674-3295$ $-10667-3285-10667-3273-10674-3267-10682-3260-10686-3250-10684-3242$ 
APPENDIX G.--Sample DLG data file (Standard Distribution Format)--continued

\begin{tabular}{|c|c|c|c|c|c|c|c|c|c|c|c|}
\hline $\begin{array}{l}-10677 \\
-10653 \\
-10654 \\
-10659 \\
-10613 \\
-10554 \\
-10519\end{array}$ & \multicolumn{2}{|c|}{$\begin{array}{l}-3242-10669 \\
-3194-10656 \\
-3138-10655 \\
-3076-10657 \\
-3046-10604 \\
-2971-10547 \\
-29,12-10515 \\
\ldots \ldots-10021\end{array}$} & $\begin{array}{l}-3240- \\
-3185- \\
-3128- \\
-3066- \\
-3039- \\
-2961- \\
-2904- \\
-869-\end{array}$ & $\begin{array}{l}10664 \\
10658 \\
10656 \\
10651 \\
10594 \\
10540 \\
10511 \\
10021\end{array}$ & $\begin{array}{l}-3239 \\
-3175 \\
-3117 \\
-3057 \\
-3030 \\
-2949 \\
-2895 \\
-863\end{array}$ & $\begin{array}{l}0656 \\
0659 \\
0658 \\
0644 \\
0587 \\
0532 \\
0504 \\
.0023\end{array}$ & $\begin{array}{l}-3235- \\
-3169- \\
-3108- \\
-3053- \\
-3020- \\
-2938- \\
-2885- \\
-857\end{array}$ & $\begin{array}{l}10652 \\
10658 \\
10659 \\
10633 \\
10579 \\
10526 \\
10501\end{array}$ & $\begin{array}{l}-3220- \\
-3158- \\
-3097- \\
-3047- \\
-3012- \\
-2928- \\
-2878-\end{array}$ & $\begin{array}{l}10651 \\
10656 \\
10659 \\
10621 \\
10567 \\
10523 \\
10496\end{array}$ & $\begin{array}{l}-3206 \\
-3149 \\
-3086 \\
-3045 \\
-2993 \\
-2921 \\
-2868\end{array}$ \\
\hline L & $\because \cdots$ & 7 & 8 & 2 & 24 & & 1 & 0 & & & \\
\hline 1307 & 63 & 1295 & -1175 & 1286 & -1188 & 1277 & -1193 & 5 & -1194 & 1252 & -1190 \\
\hline 1238 & -1187 & 1230 & -1187 & 1223 & -1192 & 1211 & -1198 & 1199 & -1203 & 1184 & -1208 \\
\hline 1176 & -1213 & 1157 & -1228 & 1136 & -1243 & 1126 & -1253 & 1117 & -1261 & 1105 & -1267 \\
\hline 1092 & -1275 & 1085 & -1277 & 1073 & -1274 & 1062 & -1270 & 1052 & -1270 & 1039 & -1272 \\
\hline 1022 & -1279 & 1012 & -1279 & 998 & -1278 & 982 & -1274 & 970 & & 954 & -7 \\
\hline 946 & -1270 & 932 & -1268 & 933 & -1258 & 935 & -1248 & 933 & -12 & 921 & -1 \\
\hline 913 & -1228 & 905 & -1216 & 905 & -1213 & 912 & -1203 & 923 & -1198 & 941 & -1199 \\
\hline 957 & -1203 & 963 & -1200 & 970 & -1196 & 976 & -1186 & 982 & -1180 & 983 & -1179 \\
\hline & & 992 & -1170 & 1006 & -1162 & 1018 & -1155 & 1042 & -1145 & 1055 & -1137 \\
\hline 1057 & -1118 & 1048 & -1109 & 1040 & -1100 & 1033 & -1093 & 1026 & -1090 & 1017 & -1084 \\
\hline & & & 2017 & & & & & & & & \\
\hline
\end{tabular}




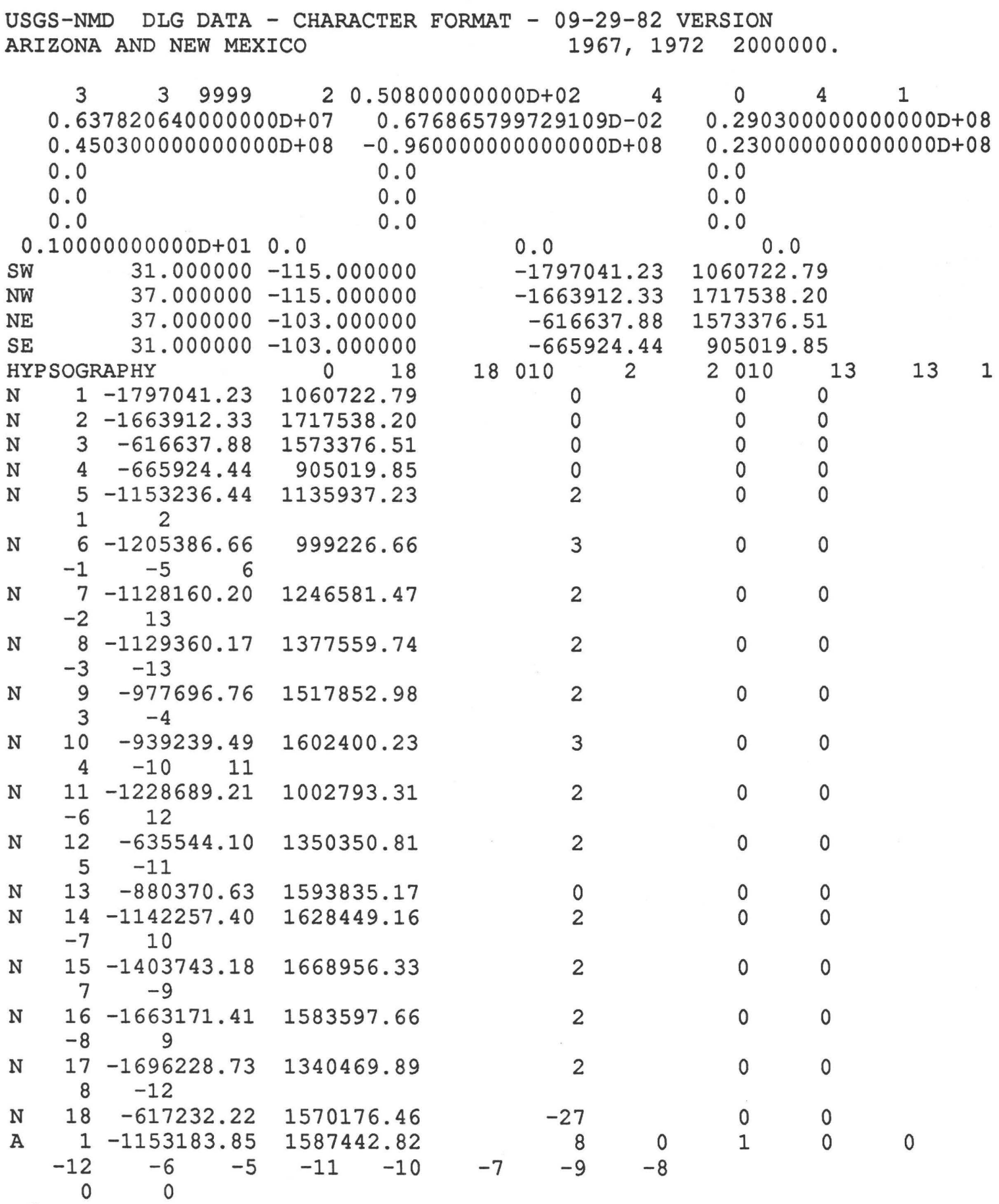


APPENDIX H.--Sample DLG data file (Optional Distribution Format)--continued

\begin{tabular}{|c|c|c|}
\hline-115 & 62.93 & 306.99 \\
\hline 12 & 9 & 10 \\
\hline L & 6 & 2 \\
\hline 1153236.44 & 1135937.23 & -1153966.87 \\
\hline-1154737.04 & 1134349.03 & -115512 \\
\hline-1156040.00 & 1133451.52 & -115642 \\
\hline-1156559.97 & 1131164.26 & -11 \\
\hline-1157281.64 & 1130391.85 & -1157567 \\
\hline-1158095.21 & 1129324.42 & -1158308 \\
\hline-1158629.44 & 1128423.66 & -1158881 \\
\hline-1159821.56 & 1128331.36 & -11 \\
\hline-1160989.24 & 1127671.63 & -116 \\
\hline-1161546.08 & 1126979.10 & -1161608.43 \\
\hline-1161899.79 & 1125899.65 & -1161998.6 \\
\hline-1161679.13 & 1124894.97 & -1161368. \\
\hline$\cdots$ & & \\
\hline
\end{tabular}

L 2

$-1153236.44$

$-1151794.52$

$-1150991.14$

$-1150177.57$

$-1149716.29$

$-1148532.92$

$-1147601.19$

$-1147480.16$

$-1147938.99$

$-1147760.71$

$-1145050.03$

$-1145899.04$

$-1145911.46$

$-1144495.42$

$-1142900.69$

$-1142951.42$

$-1142243.60$

...........

L

$\begin{array}{rr}3 & 9 \\ -977696.76\end{array}$

$-979065.74$

$-980314.72$

$-981069.20$

$-981844.46$

$-982966.50$

$-984482.79$

$-987885.57$

$-989632.71$

\begin{abstract}
$\begin{array}{crc}7 & 2 & 2 \\ 1135937.23 & -1152728.09\end{array}$
$1136354.10-1151542.89$

$1136602.46-1150633.77$

$1137669.89-1150007.65$

$1138785.81-1149443.88$

$1139186.99-1148217.12$

$1139622.80-1147401.72$

$1141247.07-1147433.50$

$1143874.19-1147986.05$

$1145541.86-1147641.11$

$1157783.39-1145202.84$

$1159438.64-1145980.74$

$1160465.93-1145458.53$

$1160322.29-1143568.78$

$1160359.16-1142781.09$

$1161853.24-1142838.75$

$1162524.99-1141971.19$

$\begin{array}{ll}-1128160.20 & 1246581.47\end{array}$

\begin{tabular}{|c|c|}
\hline 8 & 2 \\
\hline 1517852.98 & -978191.26 \\
\hline 1517220.96 & -979430.04 \\
\hline 1515598.11 & -980585.29 \\
\hline 1514214.87 & -981303.30 \\
\hline 1512680.66 & -982120.13 \\
\hline 1510117.32 & -983287.40 \\
\hline 1508787.67 & -985825.89 \\
\hline 1508281.77 & -988444.25 \\
\hline 1507137.74 & -990010.86 \\
\hline
\end{tabular}
\end{abstract}

$\begin{array}{rrcr}8 & 0 & 0 & 0 \\ 5 & 6 & & 0 \\ 1135473.71 & -1154351.95 \\ 1134145.89 & -1155568.12 \\ 1132529.98 & -1156541.02 \\ 1130818.91 & -1157009.23 \\ 1130174.86 & -1157888.81 \\ 1128892.28 & -1158443.82 \\ 1128458.30 & -1159283.67 \\ 1127954.64 & -1160716.83 \\ 1127598.69 & -1161396.94 \\ 1126526.17 & -1161700.32 \\ 1125554.30 & -1161982.92 \\ 1124544.52 & -1160962.15\end{array}$

364

1

$1136277.49-1152355.02$

$1136319.46-1151378.06$

$1136963.50-1150326.72$

$1138159.29-1149851.58$

$1138902.15-1149070.82$

$1139246.07-1147887.45$

$1139954.30-1147375.84$

$1141958.56-1147631.54$

$1144649.86-1147887.24$

$1146038.19-1147219.55$

$1158163.38-1145369.50$

$1159962.68-1146126.62$

$1160403.58-1144969.13$

$1160348.57-1143159.25$

$1160855.49-1143020.70$

$1162299.24-1142616.66$

$1162641.33-1141726.49$

461

1517613.37

1516809.59

1515122.57

1513631.75

1511795.58

1509648.70

1508716.16

1507948.44

1506625.72
1 $-978729.15$ $-979945.32$ $-980842.02$ $-981502.77$ $-982631.74$ $-983622.16$ $-986716.06$ $-989211.15$ $-990762.08$
0

1134911.37

1133899.36

1131674.44

1130508.19

1129706.25

1128654.50

1128513.72

1127787.97

1127317.52

1126231.14

1125295.74

1123770.69

1136379.97

1136399.33

1137331.47

1138548.04

1139004.64

1139405.81

1140514.81

1142755.01

1144995.21

1146492.95

1158442.72

1160392.99

1160233.66

1160343.47

1161349.98

1162422.51

1162556.37

1517431.02 1516419.01 1514747.67 1513300.25 1510686.59 1509079.43 1508582.30 1507592.50 1506011.22 
APPENDIX H.--Sample DLG data file (Optional Distribution Format)--continued

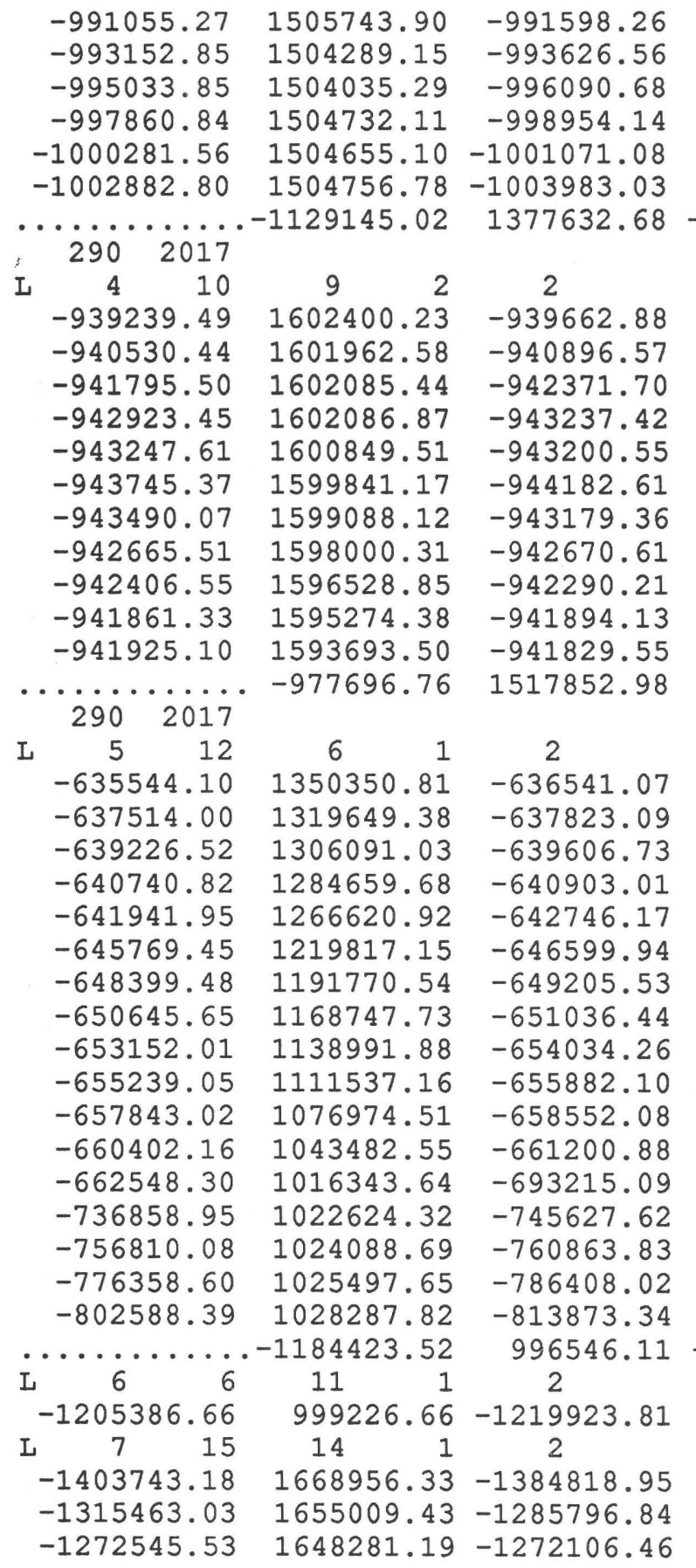

1505152.02 1504200.52 1504180.77 1504985.17 1504507.39 1504959.51 $-1129360.17$ 229
1602304.67
1601910.42
1602369.87
1601668.58
1600073.85
1599644.96
1598737.68
1597590.78
1596256.44
1594663.54
1593270.12

125 1334540.24 1314051.22 1300348.82 1281246.30 1256680.92 1210803.78 1182189.74 1163673.61 1128857.50 1102395.43 1068098.27 1032464.93 1018565.16 1023369.85 1024441.59 1026624.60 1029379.73 $-1205386.66$ 1001279.04 1665992.38 1650361.68 $1648118.19-1271235.23$ 1377559.74 $\begin{array}{lr}1 & 0 \\ -939992.54 \\ -941392.90 \\ -942637.18 \\ -943278.99 \\ -943422.63 \\ -943901.44 \\ -942731.52 \\ -942524.72 \\ -942187.73 \\ -941940.79 \\ -941834.64\end{array}$ $0 \quad 0$ $-637028.45$ $-638446.57$ $-640041.95$ $-641318.26$ $-643918.56$ $-647757.87$ $-650310.27$ $-652314.99$ $-654629.22$ $-656881.71$ $-659496.28$ $-662221.27$ $-726846.00$ $-752181.96$ $-769545.70$ $-792984.98$ $-818862.49$ 999226.66 $-1228689.21$ $-1353217.77$ $-1273631.91$

1504516.74 1504045.88 1504456.44 1504896.54 1504581.76 1505127.60

1327274.41 1309521.92 1292716.86 1276739.62 1241458.56 1199784.32 1173419.24 1149542.72 1121555.20 1089918.36 1056023.80 1019836.88 1021604.95 1023810.57 1025072.62 1027273.55 1030015.23

1002793.31

1660873.16 1648584.57 1647741.87 
APPENDIX H.--Sample DLG data file (Optional Distribution Format)--continued

\begin{tabular}{|c|c|c|}
\hline $\begin{array}{l}-1270471.59 \\
-1263927.44 \\
-1142257.40\end{array}$ & $\begin{array}{l}1647329.08 \\
1646069.29 \\
1628449.16\end{array}$ & $\begin{array}{l}-1270074.08 \\
-1229537.57\end{array}$ \\
\hline 17 & 16 & 2 \\
\hline 96228.73 & 3404 & 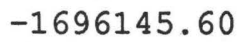 \\
\hline & & \\
\hline-1695 & & \\
\hline & & \\
\hline & & \\
\hline-16 & & \\
\hline-1 & & \\
\hline & & \\
\hline & & \\
\hline 16 & 1 & \\
\hline-16631 & .66 & - \\
\hline-166 & 92 & \\
\hline-166 & & \\
\hline-16 & & \\
\hline-16 & & \\
\hline & & \\
\hline-1 & & \\
\hline-16 & & \\
\hline 08 & & -1 \\
\hline & & \\
\hline & & \\
\hline & & \\
\hline & 1 & \\
\hline-11422 & & \\
\hline-1048 & & \\
\hline & & \\
\hline 69 & 27 & \\
\hline-9 & 49 & \\
\hline-9 & & \\
\hline 11 & 1 & \\
\hline-939 & & \\
\hline-88 & & \\
\hline & & \\
\hline-72 & 06 & \\
\hline-64 & 19 & \\
\hline 0 & & \\
\hline-62 & & \\
\hline-628 & .69 & .61 \\
\hline-633 & 1376785.17 & -6355 \\
\hline 12 & 17 & 2 \\
\hline 9.21 & 31 & \\
\hline-142 & 18 & 2 \\
\hline & & \\
\hline
\end{tabular}

$1646864.12-1269168.22$ $1640720.03-1172962.91$ $\begin{array}{rr}421 & 0\end{array}$ $\begin{array}{rcr}158 & 0 & 0 \\ 1584158.16 & -1663114.56\end{array}$ $1586363.73-1662741.90$ $1587016.53-1661645.33$ $1587785.67-1659981.33$ $1588816.63-1660335.84$ $1590862.05-1661955.43$ $1592949.45-1662419.35$ $1595297.23-1663075.82$ $1597762.77-1663584.98$ $1599753.18-1663790.35$ $1602258.86-1663973.11$ $-1403743.18 \quad 1668956.33$ $17 \quad 0 \quad 0$ $1625738.67-1084398.72$ $1612382.59-1000783.96$ $1605246.41-956912.52$ $1604727.87-955881.56$ $1603942.02-954017.68$ 1602400.23

$26 \quad 0 \quad 0$

$1600953.18-909335.93$ $1594917.85-832394.09$ $1585411.81-742432.19$ $1579539.05-675425.66$ $1573719.84-616601.41$ $1516348.30-623417.91$ $1472738.67-626831.40$ $1438356.54-629805.79$ 1350350.81 333

$1014545.24-1423412.98$ $1146656.44-1747761.96$ $1220512.22-1746936.38$
1646739.43 1632624.62

1341915.47 1343628.37 1345033.82 1346252.23 1346707.40 1347691.70 1350039.47 1352279.68

1585128.20 1586717.84 1587233.52 1587773.65 1589668.50 1591686.21 1593903.80 1595840.21 1598474.26 1600707.53 1602732.57

1620741.07 1610154.17 1605140.67 1604434.68 1603819.15

1599104.34 1591076.93 1582641.80 1577315.28 1573268.93 1516672.06 1466170.47 1428171.83

1030982.38 1219417.08 1220944.37 
APPENDIX H.--Sample DLG data file (Optional Distribution Format)--continued

\footnotetext{
$-1746672.73$

$-1745458.39$

$-1746040.09$

$-1745663.76$

$-1744558.43$

$-1744123.43$

$-1744252.19$

$-1743785.81$

$-1743779.29$

……………

$-1128160.20$

$-1129877.79$

$-1131798.92$

$-1133233.91$

$-1135099.22$

$-1137892.60$

$-1139756.07$

$-1141231.20$

$-1143306.57$

$-1145284.95$

$-1147068.96$

$-1147470.14$

$-1148438.75$

$1221369.59-1746301.50$

$1222740.80-1745375.26$

$1224102.85-1746172.11$

$1224974.08-1745247.30$

$1225180.88-1744253.22$

$1227223.44-1744212.06$

$1228523.15-1744125.67$

$1230048.60-1743766.86$

$1231586.08-1743753.41$

$\begin{array}{cc}8 & 2 \\ 1246581.47 & -1128847.24 \\ 1245279.53 & -1130488.63 \\ 1245851.66 & -1132201.53 \\ 1245485.12 & -1133872.46 \\ 1244972.70 & -1136159.32 \\ 1243306.05 & -1138400.95 \\ 1242434.43 & -1140122.21 \\ 1242893.88 & -1141734.46 \\ 1242718.05 & -1143809.83 \\ 1243246.78 & -1145881.93 \\ 1243697.47 & -1147759.67 \\ 1244880.84 & -1147543.08 \\ 1246039.75 & -1148758.22\end{array}$

$290 \quad 2017$
}

$1221831.28-1745879.94$

$1223344.71-1745685.97$

$1224633.82-1746016.04$

$1225019.31-1744988.75$

$1225908.05-1744105.91$

$1227697.15-1744243.43$

$1229069.80-1743962.67$

$1230558.78-1743740.99$

$1232146.58-1743677.21$

$\begin{array}{rcrr}408 & 1 & 0 & \\ 1246060.69 & -1129390.22 & 1245468.81 \\ 1245312.33 & -1131115.15 & 1245603.69 \\ 1245907.08 & -1132588.44 & 1245703.94 \\ 1245316.62 & -1134661.98 & 1245168.91 \\ 1244349.44 & -1137320.07 & 1243740.03 \\ 1242965.80 & -1139046.42 & 1242746.97 \\ 1242382.27 & -1140705.33 & 1242616.38 \\ 1242963.16 & -1142402.54 & 1242952.56 \\ 1242787.33 & -1144507.46 & 1242934.64 \\ 1243380.24 & -1146666.36 & 1243642.05 \\ 1243895.11 & -1147640.07 & 1244391.44 \\ 1245095.99 & -1148070.78 & 1245732.71 \\ 1246699.08 & -1148737.44 & 1246850.06\end{array}$

1222286.04

1223695.16

1225022.57

1225035.00

1226605.68

1228214.26

1229508.87

1231119.29

1232700.17

1246850.06 


\section{APPENDIX I.--Data Sources and Currency}

The published 1:2,000,000-scale National Atlas sectional maps were completely revised in 1972-73. Selected information from these maps was revised before digitizing. The source and date of the updated information are presented below:

\begin{tabular}{|c|c|c|}
\hline Category & Source & Currency of Data \\
\hline $\begin{array}{l}\text { Political Boundaries, } \\
\text { Alaskan borough boundaries }\end{array}$ & Bureau of the Census & 1979 \\
\hline Administrative Boundaries & $\begin{array}{l}\text { Administering Federal } \\
\text { agency }\end{array}$ & Various \\
\hline Roads and Trails & Various & 1980 \\
\hline Railroads & $\begin{array}{l}\text { Interstate Commerce } \\
\text { Commission }\end{array}$ & 1979 \\
\hline Streams, Alaska & Landsat imagery & 1979 \\
\hline $\begin{array}{l}\text { Water Bodies, } \\
\text { major reservoirs }\end{array}$ & $\begin{array}{l}\text { National Oceanic and } \\
\text { Atmospheric Administration } \\
\text { Sectional Aeronautical } \\
\text { Charts }\end{array}$ & $1979-80$ \\
\hline Cultural Features, airports & $\begin{array}{r}\text { Federal Aviation } \\
\text { Administration }\end{array}$ & 1980 \\
\hline Alaska pipeline & USGS maps & 1979 \\
\hline
\end{tabular}

